\author{
UNIVERSIDADE DE SÃo PAULO \\ Faculdade de Filosofia, letras e CiênCias Humanas \\ Departamento de Letras Modernas \\ Pós-Graduação em Língua e Literatura Alemã
}

Alice Fátima Fonseca do Vale

\title{
Ópio para Ovídio: o Livro do Travesseiro de Yoko Tawada em tradução
}

Versão Corrigida

SÃo PAULO 


\title{
Ópio para Ovídio: o Livro do Travesseiro de Yoko Tawada em tradução
}

\author{
Versão Corrigida \\ Dissertação apresentada ao Programa de \\ Pós-Graduação em Língua e Literatura \\ Alemã do Departamento de Letras Modernas \\ da Faculdade de Filosofia Letras e Ciências \\ Humanas da Universidade de São Paulo, \\ para a obtenção do título de Mestre em \\ Letras.
}

Área de concentração: Tradução, Literatura Alemã.

Orientador: Prof. Dr. João Azenha Junior

De acordo

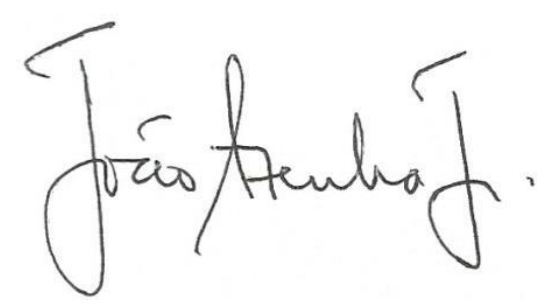

SÃo PAULO 
Autorizo a reprodução e divulgação total ou parcial deste trabalho, por qualquer meio convencional ou eletrônico, para fins de estudo e pesquisa, desde que citada a fonte.

Catalogação na Publicação

Serviço de Biblioteca e Documentação

Faculdade de Filosofia, Letras e Ciências Humanas da Universidade de São Paulo

V1490́

Vale, Alice Fátima Fonseca do

ópio para Ovídio: o Livro do Travesseiro de Yoko Tawada em tradução / Alice Fátima Fonseca do Vale ; orientador João Azenha Junior. - São Paulo, 2017. $157 \mathrm{f}$.

Dissertação (Mestrado)- Faculdade de Filosofia, Letras e Ciências Humanas da Universidade de São Paulo. Departamento de Letras Modernas. Área de concentração: Língua e Literatura Alemã.

1. Tradução. 2. Literatura Alemã. 3. Fremd. 4 . Tawada, Yoko . I. Azenha Junior, João, orient. II. Título. 


\section{AGRADECIMENTOS}

Agradeço aos meus pais, pelo apoio constante. E aos demais, poetas das palavras ou do silêncio, pessoas tão caras a mim, que me dedicam sempre sua escuta e sua mão.

Sou grata, de modo especial, às componentes da banca, as professoras Claudia Sibylle Dornbusch, Karin Volobuef e Sandra Regina Chaves Nunes, por sua leitura atenciosa.

Por fim, agradeço profundamente ao meu orientador, Professor João Azenha Junior, pelos encontros pacientes, pelas sugestões e correções valiosas, e por todas as aulas que me inspiram a perseguir o caminho da tradução. 


\section{Resumo}

O presente trabalho visa a expor as principais questões envolvidas no processo de tradução parcial do livro Opium für Ovid: Ein Kopfkissenbuch von 22 Frauen (Ópio para Ovídio: um Livro do Travesseiro de 22 mulheres), de Yoko Tawada. Com vistas ao exercício de traduzir, esta dissertação deve ser entendida como um estudo preliminar sobre a escritora e sua obra escrita em alemão, uma língua estrangeira para ela, que escreve também em japonês. Num contexto de constante migração e, ao mesmo tempo, de negação do Outro e de xenofobia, entende-se como necessária a busca por uma experiência de alteridade. Nesse sentido, esta tradução comentada, do alemão para o português do Brasil, persegue o deslocamento do olhar para uma perspectiva e uma língua estrangeiras, de modo que o texto traduzido propicie uma experiência com o fremd.

Palavras-chave: Yoko Tawada; literatura alemã; tradução literária; tradução como deslocamento e transformação; fremd. 


\section{Abstract}

This work presents the main issues involved in the partial translation process from German into Brazilian Portuguese of the book Opium für Ovid: Ein Kopfkissenbuch von 22 Frauen (Opium for Ovid: A Pillow Book of 22 Women), by Yoko Tawada. This dissertation should be understood as a preliminary study about the writer and her work written in German, a foreign language to her, who writes also in Japanese, her mother tongue. In a context of constant migration and a growing xenophobia, the experience of foreignness is considered here as necessary. By allowing the translated text to emphasize the displacement from perspectives, the goal of providing this experience with the foreign (fremd) can be achieved through the act of translating.

Keywords: Yoko Tawada; German literature; literary translation; translation as displacement and transformation; fremd.

\section{Zusammenfassung}

In der vorliegenden Arbeit sollen die wichtigsten Aspekte des Teilübersetzungsprozesses des Buches „Opium für Ovid: Ein Kopfkissenbuch von 22 Frauen“, von Yoko Tawada, behandelt werden. Im Hinblick auf die Übersetzungspraxis lässt sich diese Arbeit als Vorstudie über diese Schriftstellerin und ihr Werk verstehen, das sie sowohl auf Japanisch als auch auf Deutsch - eine Fremdsprache für sie - verfasst. In Anbetracht der ständigen Migration und einer gleichzeitig wachsenden Fremdenfeindlichkeit ist die Suche nach einer Auseinandersetzung mit der Fremdheit gefordert. In diesem Sinne verfolgt die kommentierte Übersetzung aus dem Deutschen ins brasilianische Portugiesisch die Verschiebung in die Richtung des Fremden, sodass der übersetzte Text auch eine Erfahrung damit ermöglichen kann.

Stichwörter: Yoko Tawada; Deutsche Literatur; literarische Übersetzung; Übersetzen als Verschiebung und Verwandlung; fremd. 


\section{Sumário}

Introdução.

\section{Capítulo I.}

A autora, sua obra e a multiplicidade cultural na literatura alemã.

1.1 Yoko Tawada e a multiplicidade cultural na literatura alemã

1.2 Mapeamento do subsistema como subsídio: status da autora e da obra......22

1.3 Experiência com e no estrangeiro: o fremd na obra de Yoko Tawada. 35

\section{Capítulo II.}

Ópio para Ovídio: sobre o texto e os intertextos

\section{Capítulo III.}

Tradução e nota prévia .74

3.1 Nota prévia: estratégia e método................................................75

3.2 Tradução ........................................................................... 83

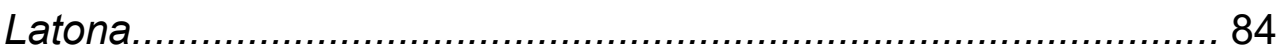

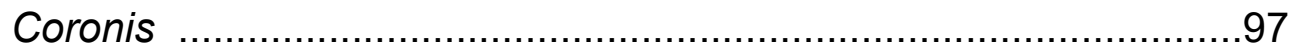

\section{Capítulo IV.}

Notas à tradução:

comentários e apresentação de exemplos

Considerações Finais 


\section{Introdução}

\section{Ser fremd é uma arte}

Encontrar-se numa terra e numa língua estrangeiras, ser o desconhecido e, ao mesmo tempo, estar no desconhecido. Sentir-se estranha, alheia, ser a pessoa de fora de uma certa lógica onde uma camada coletiva de significações é compartilhada pelos que pertencem a determinado grupo. Isso é ser fremd. Fremd por não ser reconhecido ou não se reconhecer a si mesmo em uma dada cultura. Os aspectos englobados por essa palavra alemã são fundamentais no contexto do presente trabalho, tanto pelas razões que o motivaram, quanto pelas escolhas em relação ao seu conteúdo.

No decorrer desta dissertação, nos utilizamos da gama de significados do termo fremd para traduzi-lo de acordo com o considerado mais apropriado em cada caso. Em algumas de suas ocorrências, a palavra foi deixada em alemão para possibilitar, ao mesmo tempo, a abrangência do conceito e sua concisão. Teremos oportunidade de discutir mais a fundo sobre nosso entendimento sobre o fremd já no primeiro capítulo deste trabalho. Neste momento, pontuamos os seguintes aspectos: em sua forma de atributo, a palavra pode qualificar algo como "estrangeiro", como é o caso de "língua estrangeira" (Fremdsprache). Além disso, sua acepção enquanto substantivo (Fremde) pode se referir a uma pessoa proveniente de outro país ou a alguém tido como o Outro, o alheio, em contraposição ao "eu" que o nomeia. Pode designar também o estranho, o não conhecido, o incomum e, por fim, o conjunto de países excetuando-se aquele no qual se nasce.

É possível dizer, ainda, que há certa nuance etimológica negativa do fremd apontando para o medo do desconhecido, ou até mesmo, do não-confiável. Contudo, para a escritora Yoko Tawada, ser fremd é uma arte (cf. TAWADA em entrevista a HORST, 2009:84). Tawada escreve obras literárias em alemão e em japonês, sua língua materna e parece positivar esse termo ao expor literariamente 
o significado de trazer consigo uma bagagem linguístico-cultural múltipla, cuja pluralidade frutifica em seu trabalho.

Nesse sentido, o que interessa, de fato, é a influência do caráter estrangeiro em sua obra e não exatamente como ela é categorizada. Faz-se importante esclarecer que não pretendemos traçar uma linha divisória entre a literatura alemã feita por migrantes ou aquela feita por alemães. No entanto, consideramos essencial mapear e expor o campo literário contemporâneo em que se inserem os escritores e escritoras que, como Yoko Tawada, encontraram numa língua estrangeira seu instrumento de trabalho.

Sendo assim, muito embora não nos atenhamos à busca por designações específicas para nomeá-los, entendemos ser necessária, em alguns momentos, uma referência especialmente voltada aos escritores que compõem um subsistema literário marcado por intensa troca cultural. Desta forma, nos referimos a eles com as seguintes denominações no decorrer deste trabalho: escritores e escritoras com background de migração ou de origem linguístico-cultural não alemã ou, ainda, com bagagem cultural múltipla e, também, como os nomeia Yoko Tawada, migrantes literatos.

Minha formação acadêmica foi, em grande parte, voltada para a lida com o alemão como língua estrangeira, distante, em princípio, de minha origem linguístico-cultural. Em processos como esse de deslocamento, a bagagem tornase cada vez mais heterogênea e híbrida e, no caminho, um certo estranhamento acaba por se manifestar. Os escritores e escritoras das mais variadas origens que ajudam a compor a literatura contemporânea em língua alemã deslocam-se, saem de um cotidiano onde aparentemente tudo é conhecido e previsível. Em tempos de fronteiras, seu ímpeto de lidar com a língua do Outro de modo literário despertou minha atenção e o desejo de trazer essa experiência para mais uma camada cultural através da tradução para o português. 


\section{Tradução como deslocamento: objetivos do trabalho}

Ao pensar no caráter da tradução como um deslocamento que necessariamente modifica, altera e, até mesmo, revigora a língua de chegada, optei por traduzir uma autora que costuma abordar em sua escrita o tema da língua estrangeira e do ser estrangeira ou, de modo mais amplo, entende-se a si mesma e a sua escrita como fremd. Num contexto de constante migração, de busca por refúgio, e ao mesmo tempo, de negação do Outro e de xenofobia, é latente a busca por uma experiência de alteridade. Sendo assim, perseguimos o traduzir como exercício do olhar para o deslocamento e para o estrangeiro, permitindo que o texto traduzido propicie uma experiência com o mesmo, sem a tentativa de anulá-lo.

Nesse sentido, esta dissertação visa a expor as principais questões envolvidas no processo da tradução parcial, do alemão para o português do Brasil, do livro Opium für Ovid: Ein Kopfkissenbuch von 22 Frauen (Ópio para Ovídio: um Livro do Travesseiro de 22 mulheres), publicado em 2000. O objetivo geral do presente trabalho é apresentar ao leitor brasileiro uma edição bilíngue de narrativas deste livro de Yoko Tawada, autora inédita em português. Esta dissertação deve ser entendida, assim, como um estudo preliminar sobre a autora e sua obra com vistas ao exercício de traduzir, de modo que seu objetivo específico consiste na ênfase para o desenvolvimento da tradução comentada em si.

Sobre Ópio para Ovídio destacamos, por ora, a remissão ao poeta latino Ovídio e às suas Metamorfoses, bem como ao Livro do Travesseiro, obra japonesa de Sei Shônagon. O diálogo com esses intertextos milenares permeia a longa viagem do texto até o português e se estabelece no decorrer das vinte e duas "mulheres-capítulos" que compõem esse livro de Yoko Tawada.

Quanto à sua narrativa, destacamos a construção fragmentária, sendo que a relação entre as personagens e entre as "lascas" de suas histórias cotidianas parece constantemente suscitar a desnaturalização do olhar. Nesse contexto, as personagens não apresentam uma identidade definida e têm seu cotidiano repleto de transformações voltadas à mudança física dos corpos e de objetos e à alternância de perspectivas aparentemente sedimentadas nos indivíduos de determinada sociedade. 


\section{Estrutura da dissertação}

O presente trabalho está estruturado conforme os capítulos brevemente descritos a seguir.

O capítulo 1 apresenta a autora e sua obra em meio à multiplicidade cultural da literatura contemporânea alemã e é dividido em três seções. A seção 1.1 compõe-se de uma apresentação inicial de Yoko Tawada e da literatura contemporânea alemã, mais especificamente, no que se refere aos escritores que se ocupam com as diversas camadas de suas memórias culturais. A seção 1.2, por sua vez, inclui como subsídio à discussão empreendida neste capítulo um mapeamento inicial do subsistema que engloba os escritores de língua alemã que trazem consigo uma bagagem linguístico-cultural múltipla. Ao final do capítulo 1, na seção 1.3, é exposto um panorama da obra em alemão de Yoko Tawada. $O$ recorte feito para essa exposição concentra a experiência com o fremd que reverbera na obra da escritora. Para tanto, são aprofundados, ainda nesta seção (1.3), alguns dos principais aspectos da palavra fremd, expostos brevemente no início desta introdução.

No capítulo 2, tratamos de apresentar Ópio para Ovídio e o diálogo intertextual estabelecido por Yoko Tawada nesse livro. A partir da análise dessa obra, especialmente dos dois textos traduzidos (Latona e Coronis), buscamos apresentar, em linhas gerais, o trabalho realizado pela escritora com as referências às Metamorfoses e ao Livro do Travesseiro. Para tanto, expomos, neste capítulo, a noção de intertextualidade considerada na leitura dessa obra que implica a constante reconstrução da memória literária, inclusive no que se refere ao texto traduzido.

O terceiro capítulo, por sua vez, constitui-se das traduções e de sua nota prévia. Na seção 3.1 consta a nota prévia com os aspectos teóricos que fundamentam o processo tradutório, bem como a estratégia adotada no decorrer do mesmo. Além disso, a nota traz informações sobre o método utilizado, em que a natureza da pesquisa é a tradução e a reflexão sobre ela mesma. A seção seguinte (3.2) compõe-se das traduções propriamente ditas de Latona e de Coronis, em edição bilíngue (alemão/português). Elas buscam não somente ilustrar 
os temas discutidos ao longo do trabalho, mas incorporam elas mesmas o exercício tradutório transformador realizado no decorrer deste trabalho.

Por fim, o capítulo 4 consiste nas notas à tradução, elaboradas a partir de comentários e de exemplos retirados da mesma. Neste ponto, cabe ressaltar que a tradução comentada é um tipo de tradução que, depois de realizada, dá origem a uma reflexão sobre o processo ocorrido. O texto resultante do ato tradutório é, assim, produto do trabalho e objeto de estudo. Tendo isso em vista, explicitamos, no âmbito deste capítulo, minha atitude como tradutora, considerando a visão da própria Yoko Tawada sobre tradução. Por fim, adiantamos que, a partir da leitura da obra com vistas à sua tradução, a prática tradutória consistiu em deixar transparecer o elemento estrangeiro do texto, de modo que este capítulo (4) visa a apresentar o efeito de estranhamento possivelmente gerado com esse exercício como algo que se coaduna com o traduzir entendido pela autora do texto, enquanto deslocamento em prol de uma transposição transformadora.

\section{O exercício tradutório a caminho do estrangeiro}

Conforme TAWADA (1998:35 e 36), o texto traduzido toca na superfície do texto de partida sem se fazer dependente de seu núcleo. Nesse sentido, os parâmetros relacionados à concepção de uma tradução estão vinculados, segundo a escritora, a elementos como literalidade e transformação, de modo que o texto de chegada teria um caráter de deslocamento que não deve ser apagado, mas sim considerado como um resultado revigorante. Sendo assim, o exercício tradutório exposto nesta dissertação perseguiu uma tradução comentada que busca recuperar o caráter literário do texto de partida através de um jogo de compensações, pautado principalmente pelo trabalho com a experiência estética ligada ao estrangeiro.

Faz-se importante ressaltar que essa experiência não se constitui em subserviência ao estrangeiro, mas sim em uma tentativa de criar algo particular através do contato com a língua estrangeira. Dessa forma, a prática tradutória não busca negligenciar a língua portuguesa ou tampouco decalcar a língua alemã de 
modo impensado na língua de chegada. Reiteramos que a ideia do exercício tradutório aqui desenvolvido é deixar transparecer o caráter fremd do texto de partida, fazendo com que o leitor seja levado a ter contato com esse Outro, em princípio, distanciado de si.

A linguagem de Yoko Tawada contém em si mesma um caráter estrangeiro e desvela uma simplicidade capaz de deslocar o olhar do leitor para uma perspectiva e uma língua outras e para a necessidade de não rechaçarmos a diferença. Assim, o ato de traduzir Ópio para Ovídio implicou o respeito pela diferença, de modo que o processo apresentado ao longo desta dissertação buscou um texto não reduzido ao já conhecido pela cultura de chegada. Esse exercício se deu pelo constante deslocamento entre as duas línguas para que o próprio e o alheio, a origem e o destino, pudessem conviver de alguma forma nessa tradução, vista como uma transformação calcada no caminho que preenche o distanciamento e o hiato estabelecidos pelo fremd. 


\section{Capítulo I}

\section{A autora, sua obra e a multiplicidade cultural na literatura contemporânea alemã}

Este capítulo procura traçar um panorama sobre a multiplicidade cultural na literatura contemporânea alemã. O objetivo desta apresentação inicial é explicitar o subsistema literário em que Yoko Tawada e a obra traduzida nesta pesquisa estão inseridas. Sendo assim, através de um levantamento sobre alguns agentes atuantes na literatura alemã, é possível, além de identificar o contexto em que o livro se insere, analisar de modo crítico categorias em que são englobados os escritores e escritoras com background de migração. A partir dessa apresentação de caráter mais geral, nos detemos, ao final desta primeira parte, na obra de Yoko Tawada.

Para tal exposição, este capítulo está dividido em três partes: a seção 1.1 trata de Yoko Tawada e dos escritores com uma bagagem cultural diversa; a seção 1.2, por sua vez, versa sobre o mapeamento do subsistema literário como subsídio para a compreensão do status da autora e de sua obra e, por fim, a seção $1.3 \mathrm{diz}$ respeito ao fremd, ou mais especificamente, à experiência com e no estrangeiro na obra de Yoko Tawada.

\subsection{YoKo tAWADA E A MULTIPLICIDADE CULTURAL NA LITERATURA ALEMÃ}

Da janela de um trem ela observa a Europa se aproximando pela Transiberiana. A Ásia foi pouco a pouco ficando para trás e, dentro de si, a água europeia tomada a transforma lentamente, assim como lento é o seu deslocamento. 
Tawada percebe o Ich (Eu) como água, um Eu sem identidade, um corpo em movimento, que pode correr, que não tem uma forma, que está no centro e percebe o mundo e, ao perceber o mundo, se metamorfoseia. Segundo essa concepção, Yoko Tawada diz se constituir de um híbrido de Europa e Japão:

Foi algo especial para mim ter feito essa viagem muito lenta para a Europa, não como a maioria dos turistas e visitantes que chegam de imediato e percebem a cultura estrangeira somente com os olhos, como uma paisagem, mas sim como aquele que lentamente se transforma a si mesmo na viagem (...) Eu escrevi, por exemplo, que o ser humano se compõe de até 80 por cento de água, ou seja, se durante essa viagem eu sempre bebo água estrangeira, uma água europeia ou uma água que se torna mais europeia a cada dia, então, eu mesma também serei outra quando chegar." ${ }^{1}$ (TAWADA em entrevista a SAALFELD 2002:185)

Nascida em Tóquio em 1960, onde se formou em Teoria Literária com ênfase em Literatura Russa, Yoko Tawada mora na Alemanha desde 1982. Foi para o país ocupar uma vaga oferecida pela pequena empresa do pai, que importava livros europeus de especialidade. Em Hamburgo, cursou também Germanística, trabalhou como intérprete e começou a escrever textos literários em alemão. Desde 1987, a autora possui livros lançados em alemão e desde 1991, em japonês. A obra sobre a qual o presente trabalho se concentra, Opium für Ovid: Ein Kopfkissenbuch von 22 Frauen (Ópio para Ovídio: um Livro do Travesseiro de 22 mulheres), foi publicada na Alemanha em 2000 e, neste mesmo ano, foi traduzida para o japonês pela própria autora.

Yoko Tawada morou em Hamburgo até 2006, quando se mudou para Berlim. Em entrevista a SCHOMANN (2009:9-10), a autora faz as seguintes observações sobre essa cidade:

1 As traduções contidas neste trabalho foram feitas por mim, salvo as citações que não constam na língua original em nota. Nesse caso, o tradutor ou tradutora constará nas referências bibliográficas.

„Das war für mich etwas Besonderes, diese sehr langsame Fahrt nach Europa gemacht zu haben; nicht wie die meisten Besucher oder Touristen, die sofort ankommen und nur mit Augen die fremde Kultur wie eine Landschaft wahrnehmen, sondern dass man in der Fahrt sich selbst langsam verändert (...) Ich habe zum Beispiel geschrieben, dass der Mensch zu 80 Prozent aus Wasser besteht, das heißt, wenn ich während dieser Fahrt, immer fremdes Wasser trinke, ein europäisches Wasser oder ein Wasser, das jeden Tag europäischer wird, dann werde ich ja selbst anders wenn ich ankomme." 
Em Berlim, utiliza-se frequentemente a expressão "no Oriente". Isso pode denominar muitas coisas. Dentro da cidade, isso significa a antiga Berlim Oriental. Para outros, o Oriente começa na Polônia, ou na Ucrânia, ou nos Urais. O legal de Berlim é que o Ocidente e o Oriente estão disponíveis em uma cidade, como categorias. É uma cidade no limiar. Quando vou passear por Pancow, estou, na minha cabeça, já quase na Rússia: anel Majakowski, caminho Boris-Pasternak, rua Tschaikowsky. E há essas ruas largas, retas como a avenida Prenzlauer, que parecem me levar direto para Moscou ou mais além para Pequim. Em Hamburgo, não havia esse tipo de rua. ${ }^{2}$

A representação de uma reta imensa ligando Ocidente e Oriente nos reporta ao tema da viagem, uma constante na biografia de Yoko Tawada e também trabalhada literariamente em seus textos. Sua perspectiva de deslocamento envolve uma atitude frente a si mesma e ao Outro. A necessidade de pensar sobre seu Eu não existiria, segundo ela, se não tivesse ido para a Europa, onde, ao se deparar com o estrangeiro e se alimentar dele, transforma e é transformada.

Uma outra dimensão desse deslocamento se refere ao alcance de sua literatura. Ao ser perguntada se o conceito de "literatura internacional" se aplicaria a ela, Tawada diz, em entrevista a SchOMANN (2009:10):

Na medida em que não quero produzir uma literatura nacional, eu poderia dizer que escrevo literatura internacional. Por outro lado, não dou muito valor para a palavra "internacional". Isso pois muitos países permanecem de fora, porque não posso ir até lá ou porque a literatura é reprimida ali, ou porque muitas pessoas ali não sabem ler. Eu viajo, na maioria das vezes, apenas na Europa e na América do Norte. (...) Mas é claro que acho bom que textos meus sejam lidos em diferentes culturas. Isso é mais importante para mim do que ser avaliada num país, num estrato da sociedade, como alta literatura. ${ }^{3}$

2 „In Berlin benutzt man häufig diesen Ausdruck „im Osten“. Das kann ganz Verschiedenes bezeichnen. Innerhalb der Stadt meint es das frühere Ost-Berlin. Bei anderen fängt der Osten in Polen an, oder in der Ukraine, oder am Ural. Das Tolle in Berlin ist, dass West und Ost in einer Stadt vorhanden sind, als Kategorien. Es ist eine Stadt auf der Schwelle. Wenn ich in Pankow spazieren gehe, bin ich im Kopf schon fast in Russland: Majakowski-Ring, Boris-Pasternak-Weg, Tschaikowsky-Straße... Und es gibt diese breiten, geraden Straßen wie die Prenzlauer Allee, die sehen aus, als würden sie mich direkt nach Moskau oder weiter nach Peking bringen. In Hamburg gab es keine solche Straßen."

3 „Insofern ich keine nationale Literatur produzieren möchte, könnte ich sagen, dass ich internationale Literatur schreibe. Andererseits halte ich nicht viel vom Wort „international“. Denn viele Länder bleiben außen vor, weil ich nicht hinfahren kann oder weil die Literatur dort unterdrückt wird, oder weil so viele Menschen dort nicht lesen können. Ich bin ja meist nur in Europa und Nordamerika unterwegs. (...) Aber ich finde natürlich toll, dass Texte von mir in unterschiedlichen Kulturen gelesen 
No que diz respeito ao contato com diferentes culturas na própria Alemanha, Tawada diz em entrevista a SAALFELD (2002:190):

O que eu gosto também na Alemanha é de ter a possibilidade de conhecer muitos autores da Áustria, do Leste Europeu, da Turquia e de outros mundos. Aqui é para mim como um centro literário da Europa, para onde as pessoas que escrevem vêm e fazem apresentações literárias juntas. ${ }^{4}$

As obras desses escritores são comumente agrupadas em uma categoria específica para autores com origem linguístico-cultural não alemã. Segundo EMMERICH (2006:128), não se encontrou uma denominação adequada para a literatura desses escritores. O autor enumera sugestões antigas como: "Gastarbeiterliteratur" (literatura dos trabalhadores "convidados"), "Literatur der Fremde" (literatura do estrangeiro) e "interkulturelle Literatur" (literatura intercultural). Mais recentemente, ainda segundo EMMERICH, fala-se em "Migrantenou Migrationsliteratur" (literatura de migrantes ou literatura de migração).

Acrescentamos outros termos encontrados em artigos, trabalhos acadêmicos e outras publicações: "Ausländerliteratur" (literatura dos estrangeiros), "Minderheitenliteratur" (literatura das minorias), "deutsche Literatur von außen" (literatura alemã de fora), "multikulturell" (multicultural), "nicht nur deutsch" (não somente alemã) ou "MigrantInnen Literatur" (literatura de homens e mulheres migrantes).

Franco Biondi é um dos escritores da chamada Gastarbeiterliteratur, literatura composta por trabalhadores que migraram para a Alemanha para a reconstrução do país nos anos 50 , sendo nomeados de Gastarbeiter. A palavra Gast (convidado, visitante) pode implicar uma ideia de que os trabalhadores (Arbeiter) voltariam para seus países ao final de um determinado período de trabalho. Muitos deles permaneceram na Alemanha e alguns, como é o caso de Biondi, passaram a escrever textos literários em alemão. Biondi introduziu termos

werden. Das ist mir wichtiger, als in einem Land, in einer Schicht als hohe Literatur bewertet zu werden."

4,Was mir auch an Deutschland gefällt ich habe die Möglichkeit viele Autoren aus Österreich, Osteuropa, der Türkei und aus anderen Welten kennenzulernen. Das ist für mich wie ein literarisches Zentrum Europas, wohin die schreibenden Menschen kommen und zusammen Lesungen machen." 
como Gastarbeiterliteratur (BIONDI em entrevista a AMODEO, 2009:10) e, juntamente com Rafik Schami, escreveu e publicou em 1981 o ensaio Literatur der Betroffenheit. Bemerkungen zur Gastarbeiterliteratur (Literatura da Consternação. Observações sobre a Literatura de Trabalhadores Convidados) (cf. AMODEO, 2009:6). Segundo BIONDI, a ideia era usar a denominação Gastarbeiterliteratur como possibilidade de atacar a sociedade, de alterar e ampliar os significados atribuídos à denominação Gastarbeiter. Mas, segundo o autor, percebeu somente mais tarde que um novo gueto havia sido criado, já que esse conceito implicava a reprodução dos próprios comportamentos sociais criticados por ele.

Conforme EMMERICH (2006), após essa primeira geração de Gastarbeiter, constituída principalmente por italianos, domina um grupo importante, formado pelos escritores de origem turca, cuja identidade oscila entre alemães e turcos, língua alemã e língua turca. EMMERICH cita ainda escritores de outras origens, como Yoko Tawada ou o "Sprakschöpfa" Zé do Rock, nascido no Brasil.

Serão citados na próxima seção (1.2) outros autores com as mais diversas origens linguístico-culturais, mas já é possível concluir a partir dos poucos exemplos dados até aqui que a literatura contemporânea em língua alemã se constitui dessa pluralidade. E, conforme EMMERICH (2006), justamente devido a ela, o paradigma da "Literatura Nacional" não basta para compreender a produção literária contemporânea em língua alemã que mostra no âmbito estético como os indivíduos não se reduzem ao conceito de nacionalidade.

Os escritores não são necessariamente e a priori representantes de seus países de origem ou constituídos unicamente em função de processos migratórios, mas sim indivíduos produtores de discurso e inseridos em uma rede discursiva que atribui determinada significação ao mundo. Assim, é importante refletir sobre designações como Migrationsliteratur e outras usadas em resenhas, artigos de jornais e revistas, publicações acadêmicas, divulgações sobre premiações e programas de fomento específicos, que podem ter como fundamento único a ideia de nação ou de língua nacional do escritor.

Nesse contexto, considero pertinente a seguinte afirmação de Yoko Tawada em entrevista a SAALFELD (2002:187): "A Europa sempre tentou desenvolver um autorretrato através da delimitação em relação ao estrangeiro. Por isso, a Europa 
também é algo imaginário, que os europeus construíram" ${ }^{5}$. Denominações como Migrationsliteratur podem ter o efeito de apartar de certo modo os escritores com background de migração da produção "alemã de fato", numa aparente tentativa de definir linhas claras entre o "próprio" e o "estrangeiro".

Ainda com relação às categorias mencionadas anteriormente, gostaria de apresentar algumas considerações sobre esse tema feitas pela própria Yoko Tawada, em entrevista a HORST (2009: 83). Segundo Tawada, categorias como Migrationsliteratur não descrevem realmente o que ela faz. No entanto, destaca pontos que considera positivos como, por exemplo, o Adelbert von Chamisso Preis, um prêmio literário, conquistado por ela em 1996 juntamente com Marijan Nakić, que escreve em servo-croata e alemão. Além da importância de prêmios como esse, Tawada ressalta que não teria oportunidade de ter contato com tantos autores, em sua maioria do círculo cultural islâmico ou do leste europeu, se não fosse essa categoria de premiação. Diz ter encontrado um ponto em comum entre todos, já que estes escritores trabalham com a língua alemã e, ao mesmo tempo, possuem certo distanciamento em relação a ela.

Por outro lado, é importante destacar que, conforme as observações por parte da autora, se há algo em seus textos que tenha relação com o Japão, tornase fácil para quem faz resenhas, por exemplo, escrever sobre isto: uma autora japonesa que descreve a Alemanha com olhos japoneses, diz ela (cf.TAWADA em entrevista a HORST, 2009: 83). Parece ser fácil categorizar sua literatura desta forma, para que as coisas possam ser compreendidas o mais rápido possível, mas, como diz Tawada, isso não acontece somente com autores e autoras migrantes. Atualmente, tudo precisa ser compreendido de forma rápida e fácil. Tawada faz, ainda, outras considerações a respeito do lugar ocupado pelos "MigrantesLiteratos", conforme a designação dada pela autora:

Eu não acho que sejamos discriminados ou deixados à margem como MigrantesLiteratos. Há, isso sim, uma outra subdivisão que me incomoda: aquela entre autoras e autores best-seller e não best-seller; entre o que vende bem e o que não vende bem. $E$ entre as autoras e os autores que vendem bem estão também migrantes hoje em dia. Por isso não é uma desvantagem e também não é uma

5,Europa hat immer versucht dadurch, dass es sich von den Fremden abgrenzte, ein Selbstporträt zu entwerfen. Deshalb ist Europa auch etwas Imaginäres, das Europäer gemacht haben." 
vantagem. ${ }^{6}$ (TAWADA em entrevista a HORST, 2009: 83)

Diante do exposto nesta primeira seção do trabalho, nos deparamos com o questionamento sobre como nomear a literatura feita pelos escritores com background de migração ou com origem linguístico-cultural não alemã, ou ainda, pelos Migrantes-Literatos, como diz Tawada. Na minha concepção, esses escritores e escritoras compõem a Literatura Alemã Contemporânea. É certo que o fazem a partir de uma bagagem linguístico-cultural plural, assim como plural é a sociedade alemã contemporânea. Dessa forma, mais do que uma designação específica, que se constituiria quase como uma linha divisória entre o nacional e o estrangeiro, 0 que deve ser enfatizado, a meu ver, é a sua lida com a língua alemã e os textos literários obtidos com seu trabalho.

Nesse sentido, para além de designações aparentemente restritivas, fazse importante notar que a Alemanha oferece incentivos variados para o exercício de sua carreira literária. A importância dos agentes que promovem apoio ao desenvolvimento literário dos autores, cujo trabalho envolve trocas culturais, está expressa na seguinte fala de Tawada:

Eu gostava muito de russo e queria na verdade estudar na Rússia, quando vim para a Alemanha. Mas não era possível na União Soviética naquela época, e, certamente, nem mesmo depois da perestroika, eu teria conseguido realizar meu desenvolvimento literário na Rússia, porque não há nenhum apoio para isso. $\mathrm{Na}$ Alemanha, há não somente o Chamisso-Preis, mas também no geral sempre consegui apoio concreto e informal. É possível perceber realmente que as pessoas aqui estão interessadas em que a língua alemã seja escrita por estrangeiros. Eles são muito curiosos e abertos, mas não acham isso lógico, como os americanos. (TAWADA em entrevista a HORST, 2009: 83) ${ }^{7}$

6 ,Ich denke nicht, dass man als Migranten-Literaten diskriminiert oder an den Rand gedrückt wird. Vielmehr gibt es eine andere Einteilung, die mich stört: die in Bestseller- und Nicht-BestsellerAutorlnnen; in was sich gut verkauft und was sich nicht gut verkauft. Und unter den gut verkauften Autorlnnen sind auch MigrantInnen heutzutage. Daher ist es kein Nachteil und auch kein Vorteil."

7 „Russisch mochte ich sehr gerne und ich wollte eigentlich in Russland studieren, als ich nach Deutschland kam. Aber es war nicht möglich damals in der Sowjetunion, und auch nach Perestrojka hätte ich es bestimmt nicht geschafft, meine literarische Entwicklung in Russland zu vollziehen, weil es keine Unterstützung dafür gibt. In Deutschland gibt es nicht nur den Chamisso-Preis, sondern im Allgemeinen habe ich immer konkrete und auch formlose Unterstützung. Man merkt wirklich, dass die Leute hier interessiert sind daran, dass die deutsche Sprache von Ausländern geschrieben wird. Sie sind sehr neugierig und offen, aber sie halten es nicht für selbstverständlich wir die Amerikaner." 
Sendo assim, considera-se necessária, no âmbito dessa discussão, uma apresentação das questões que envolvem o trabalho desses autores e autoras no que se refere à literatura alemã. Portanto, antes de nos atermos à obra de Yoko Tawada e, mais especificamente, ao livro Ópio para Ovídio, apresentamos na próxima seção (1.2), um levantamento inicial sobre alguns agentes envolvidos no subsistema literário em que se insere a autora e sua obra

\subsection{MAPEAMENTO DO SUBSISTEMA COMO SUBSíDIO: STATUS DA AUTORA E DA OBRA}

No âmbito desta dissertação em que pretendemos apresentar Yoko Tawada e traduzir parcialmente um de seus livros, faz-se importante tratar do sistema literário em que obra e autora estão inseridas, de modo a situá-las num contexto maior, para além de categorias por vezes insuficientes para contemplar a multiplicidade cultural na literatura contemporânea alemã. Essa necessidade de buscar parâmetros fora do livro para a análise de uma tradução ou a realização da mesma está embasada nos estudos descritivos, na teoria dos polissistemas e no papel dos agentes em determinado sistema literário.

Nesse sentido, ressaltamos que a competência cultural do tradutor apresenta importância fundamental e, de modo geral, tornou-se parte da competência tradutológica a partir da "virada cultural" (Cf. AZENHA, 2010: 37-66), ocorrida nos Estudos da Tradução. Assim, quando a visão de caráter normativo e prescritivo deu lugar a uma visão mais prospectiva e descritiva, a competência tradutológica deixou de coincidir com a linguística e passou a incluir diversos elementos, como os de ordem cultural.

Considerando esses aspectos, esta seção 1.2 engloba dois eixos principais: inicialmente, apresentamos um breve quadro teórico baseado nas teorias descritivas e, em seguida, o mapeamento propriamente dito, que visa a caracterizar, segundo alguns de seus aspectos, o subsistema literário específico em que se encontram os autores das mais variadas origens linguístico-culturais. 
Sobre as teorias descritivas, ressaltamos que elas propõem a análise de tudo o que envolve o texto a ser estudado e traduzido. EVEN-ZOHAR foca na relação entre os sistemas em que estão inseridos os textos e conceitua um polissistema, como definido por SHUTTLEWORTH e COWIE (1997:176, citado em MUNDAY, 2008:108), como "um conglomerado (ou sistema) de sistemas heterogêneo, hierarquizado, que interagem para provocar um processo contínuo, dinâmico de evolução no polissistema como um todo." 8

Considerando o fato de que esse conglomerado de sistemas seja hierárquico e dinâmico, parece importante identificar determinados fatores presentes nesta hierarquização e, a partir daí, reunir elementos para caracterizar a dinâmica em que se encontram os Migrantes-Literatos, como os nomeia Tawada ou, conforme expusemos anteriormente na seção 1.1, os escritores e escritoras com uma origem linguístico-cultural não alemã.

Pode-se dizer que categorias como Migrationsliteratur - e outras apresentadas também na seção 1.1 - apresentam um caráter sociológico, pois se utilizam de conceitos que envolvem os processos migratórios, a constituição de minorias, além de aspectos de ordem cultural, para definir um determinado tipo de literatura.

Devido à complexidade dessa dinâmica, acredito ser importante considerar que, segundo SIMEONI (1998:4), o modelo descritivo apresenta potencial para abranger questões de ordem sociológica e antropológica. Portanto, antes de apresentar o subsistema em que se encontram a autora e a obra traduzida no âmbito desta dissertação, expomos brevemente algumas questões de ordem sociológica referentes aos agentes e ao seu poder no espaço social, conforme um dos aspectos da teoria desenvolvida por BOURDIEU (1990):

Não existe um interesse, mas interesses, variáveis segundo o tempo e o lugar, quase ao infinito. Em minha linguagem, eu diria que há tantos interesses quantos campos, enquanto espaços de jogo historicamente constituídos, com suas instituições específicas e suas leis próprias de funcionamento. A existência de um

8 "The polysystem is conceived as a heterogeneous, hierarchized conglomerate (or system) of systems which interact to bring about an ongoing, dynamic process of evolution within the polysystem as a whole." 
campo especializado e relativamente autônomo é correlativa à existência de alvos que estão em jogo e de interesses específicos: através dos investimentos indissoluvelmente econômicos e psicológicos que eles suscitam entre os agentes dotados de um determinado habitus, o campo e aquilo que está em jogo nele (eles próprios produzidos enquanto tal pelas relações de força e de luta para transformar as relações de força constitutivas do campo) produzem investimentos de tempo, de dinheiro, de trabalho, etc. (BOURDIEU, 1990:126-127)

Não pretendemos discorrer, no âmbito desta dissertação, sobre os conceitos de "campo", "hábito" e "capital" desenvolvidos por BOURDIEU, ressaltamos apenas que a relação entre esses três elementos se dá, segundo o autor, na medida em que os agentes sociais estabelecem e consolidam suas posições de poder no espaço social por sua participação na aquisição de formas específicas de capital. Conforme exposto na citação acima, os investimentos em campos especializados se dão de acordo com interesses específicos, sendo fundamental a relação entre o campo e a distribuição de capital. Neste contexto, as relações de força coexistem com a luta para transformá-las, sendo fundamental o exame das estruturas que produzem as disposições dos atores para evitar que o conservadorismo social seja mantido.

Partindo do pressuposto da importância de um exame dessas estruturas, INGHILLERI (2005:129) destaca que a atividade acadêmica acontece em relação a um campo de poder determinado e que o ponto inicial de uma pesquisa seria a investigação empírica de práticas relevantes, a sua localização em campos particulares e as características do capital envolvido.

No caso do subsistema que buscamos apresentar neste trabalho, a complexidade das relações de força envolve práticas moldadas por um contexto que perpassa diferentes culturas. Segundo SIMEONI:

Tão logo as práticas relevantes - não somente aquelas dos tradutores, mas também de editores, editoras e leitores - são moldadas significativamente por hábitos transculturais, ou também hábitos desenvolvidos não só do centro modal da cultura anfitriã, mas até mesmo mais radicalmente fora daquela cultura, quais são as consequências? O que temos aqui, uma vez que as poderosas noções de "campo", "hábito" e "capital" são ligadas ao amplo polissistema de culturas, é uma ordem extremamente potente de conceitos que podem explicar fenômenos 
durante muito tempo restritos à periferia, gradualmente se tornando centrais. ${ }^{9}$ (SIMEONI 1998:20)

Esse movimento em direção ao centro do sistema literário pode ser observado na dinâmica, apresentada mais adiante, que envolve programas de fomento, incentivo e publicação de autores que escrevem em alemão como língua estrangeira. Serão apresentados alguns dos fatores que parecem determinar uma tendência à centralização desses fenômenos literários, outrora mais periféricos. Os critérios que determinam essa posição central podem ser pautados em questões de ordem econômica, como as vendas, além das premiações concedidas e das editoras que publicam determinadas obras.

A referida dinâmica perpassa diferentes culturas e envolve também a tradução e as formas através das quais grupos e sociedades negociam a importação e transferência de repertório. SIMEONI (1998:22) afirma que existe uma certa subserviência por parte do tradutor, mas ela não é passiva. Neste sentido, gostaríamos de enfatizar, conforme BANDIA e MILTON (2008), o papel do tradutor em termos de mudança e inovação cultural. Ainda segundo os autores, o papel do tradutor enquanto agente pode se apresentar de duas formas:

(...) aqueles que efetuaram mudanças em estilos de tradução, ampliaram a gama de traduções disponíveis, ou aqueles que tentaram ou ajudaram a inovar ao selecionar novas obras para serem traduzidas e ao introduzir novos estilos de tradução para obras que entram em sua própria sociedade. ${ }^{10}$

(BANDIA e MILTON, 2008:2)

No que se refere ao conceito dos agentes responsáveis por introduzir novos elementos em uma cultura estrangeira, é importante notar, ainda segundo BANDIA

9 "As soon as the relevant practices - not only those of translators, but editors, publishers and readers - are shaped significantly by cross-culture habituses or else by habituses trained away not only from the modal centre of the host culture but even more radically outside of that culture, what are the consequences? What we have here once such powerful notions as "field", "habitus" and "capital" are plunged into the wider polysystem of world cultures, is an extremely potent order of concepts which may account for phenomena long restricted to the periphery, gradually becoming central."

10 "(...) those who have effected changes in styles of translation, have broadened the range of translations available, or who have helped or attempted to innovate by selecting new works to be translated and introducing new styles of translation for works entering their own society." 
e MILTON (2008) que, apesar de escrever em francês, BoURDIEU usa o termo "gatekeepers", mas agentes da tradução são, segundo eles, muito mais do que gatekeepers. Os agentes ou "agência" no que se refere aos Estudos da Tradução podem ser, conforme BANDIA e MILTON (2008:1), produtores, mediadores que modificam o texto, assim como os que escrevem resumos, editores, revisores, tradutores, encarregados e editoras. Além disso, têm papel importante os "patronos" da literatura, mecenas, organizadores de eventos, políticos ou companhias que ajudam a manter ou transformar políticas linguísticas e culturais. Podem ser também revistas, jornais ou instituições.

Tendo em vista o breve aporte teórico apresentado até aqui, estão contemplados no mapeamento abaixo ${ }^{11}$ dois grupos de agentes envolvidos no sistema literário estudado. Em primeiro lugar, são expostas informações sobre o grupo que engloba fundações e organizações voltadas ao fomento da literatura alemã e de sua tradução. Em seguida, apresentamos o grupo de agentes formado por editoras relevantes no âmbito da publicação de obras literárias em língua alemã e enumeramos autores de origem linguística não alemã ou aqueles com background de migração por elas publicados.

Não ambicionamos desenvolver uma análise quantitativa e estatística aprofundada, mas apenas apresentar um levantamento parcial desses agentes e sua atuação no sistema literário contemporâneo alemão, de modo a identificar uma parte de sua dinâmica e o posicionamento de autores específicos neste sistema.

Na Alemanha, segundo levantamento de 2014 feito pela secretaria de estatística, a porcentagem de imigrantes ou pessoas de origem não alemã - na pesquisa empregam o termo Migrationshintergrund (background de migração) nunca foi tão alta e representa $20 \%$ da população, isto é, 16,4 milhões de pessoas. A pesquisa destaca, ainda, que a maioria dessas pessoas (56\%) tem passaporte alemão ${ }^{12}$. Essa presença de outras línguas e culturas em contato com a sociedade alemã não poderia deixar de refletir na produção literária nesta língua.

11 Última atualização dos dados: janeiro de 2017.

12 Statistisches Bundesamt:

https://www.destatis.de/DE/ZahlenFakten/GesellschaftStaat/Bevoelkerung/MigrationIntegration/ Migrationshintergrund/Migrationshintergrund.html 
Dentre as organizações, cuja ênfase está no fomento conferido aos autores que apresentam trabalhos relacionados a trocas culturais, está a Robert Bosch Stiftung (Fundação Robert Bosch) responsável pelo prêmio Adelbert-von-Chamisso que desde 1985 contempla autores que escrevem em alemão e cuja obra seja, segundo consta no site da fundação ${ }^{13}$, marcada por uma troca cultural. Estes escritores devem ainda, segundo a fundação, combinar a esta questão uma forma excepcional de lidar com a língua no âmbito da literatura alemã. A maioria dos ganhadores tem uma origem linguística diferente da alemã ou possuem background de migração. O próprio escritor que dá nome ao prêmio tinha origem francesa e o francês era sua língua materna. Como dito anteriormente, Yoko Tawada ganhou o prêmio em 1996 juntamente com Marijan Nakić.

A Fundação Robert Bosch promove, ainda, inciativas em prol do contato entre tradutores e, além disso, fomenta traduções através do programa literarische Brückenbauer (construtores de pontes literárias) ${ }^{14}$. Estes "construtores de pontes literárias" são tradutores profissionais de literatura, que traduzem a partir da língua alemã ou tendo o alemão como língua de chegada. Segundo consta no website da fundação, os tradutores, vistos como mediadores entre duas culturas, devem praticar a sua arte em um alto nível.

No que se refere à organização Literarisches Colloquium Berlin - LCB (Colóquio Literário de Berlim) ${ }^{15}$, seu enfoque está no incentivo à tradução. Este incentivo possui duas vertentes: por um lado, há o fomento para tradutores, cuja língua de destino seja o alemão e, neste âmbito, o $L C B$ promove eventos de apresentação de traduções, seminários, oficinas de tradução, bolsas de trabalho, além de prêmios, como o Alfred-Döblin.

Por outro lado, há também programas de fomento para traduções a partir do alemão com iniciativas que visam, segundo consta no site da organização, divulgar informações sobre novas tendências, contatos com autores e editores, intercâmbio e conexão, através de eventos como Sommerakademie (Academia de Verão),

$13 \mathrm{http}: / / w w w . b o s c h-s t i f t u n g . d e / c o n t e n t / l a n g u a g e 1 / \mathrm{html} /$ literaturfoerderung.asp 14 Robert Bosch Stiftung: http://www.bosch-stiftung.de/content/language1/html/1098.asp 15 Literarisches Colloquium Berlin: http://www.lcb.de/home/ 
Internationale Übersetzerwerkstatt (Oficina Internacional de Tradução) e Internationale Treffen der Übersetzer deutscher Literatur (Encontro Internacional de Tradutores de Literatura Alemã). Este último projeto acontece na feira do livro de Leipzig e é feito em conjunto com a Fundação Robert Bosch. Dentre os tradutores presentes nestes encontros estão os que traduzem do alemão para a língua portuguesa. ${ }^{16}$

Acredito ser importante ressaltar que vários desses agentes aqui citados trabalham em conjunto em projetos como as bolsas Schritte (Passos), fomentadas pela Fundação S. Fischer voltadas a tradutores do sul da Europa, Rússia, Polônia e Turquia ${ }^{17}$. No âmbito do festival internacional de literatura de Leukerbad, ambas as fundações promovem anualmente um workshop com um autor suíço e tradutores escolhidos. Em 2016, por exemplo, o encontro se deu entre tradutores de literatura de todo o mundo através da cooperação entre o Instituto Goethe, S. Fischer Stiftung, Traduki ${ }^{18}$ e Stiftung Pro Helvetia ${ }^{19}$. A ideia é discutir sobre o desenvolvimento da literatura alemã contemporânea, ter contato pessoal com autores, editores e críticos e colegas de outros países. Também faz parte do projeto a presença na feira do livro de Leipzig.

Ainda com relação ao Literarisches Colloquium Berlin, ressalto o projeto Verlagsmetropolen (metrópoles editoriais) em conjundo com o Instituto Goethe e Auswärtiges Amt (secretaria que possui atribuições comparáveis às do Ministério das Relações Exteriores) com objetivo de divulgar a literatura contemporânea alemã. Esses organismos buscam o contato com editoras e tradutores e dão início a projetos de tradução de modo a angariar novos leitores de literatura contemporânea alemã. É interessante notar que o projeto sai do eixo europeu: já aconteceu na América do Sul em 2009 - Montevidéu e Buenos Aires. Em 2005, ocorreu em Tóquio e teve como participantes, além de Yoko Tawada, Marcel Beyer,

16 http://www.lcb.de/uebersetzer/sommerakademie/2012.htm

17 https://www.betterplace.org/de/organisations/12554-s-fischer-stiftung

18 Traduki é uma organização com foco em uma rede europeia de literatura da Albania, Bósnia, Bulgária, Alemanha, Kosovo, Croacia, Liechtenstein, Macedonia, Montenegro, Austria,

Romênia, Suíca, Sérvia e Eslovenia.

19 Fundação suíça de fomento a criações artísticas: http://www.prohelvetia.ch/FOERDERUNG.7.0.html 
John von Düffel, Felicitas Hoppe, Kathrin Röggla, Ingo Schulze e Hubert Winkels. ${ }^{20}$

Com relação ao Instituto Goethe, seus objetivos são, segundo divulgado pela instituição, ${ }^{21}$ promover o conhecimento da língua alemã no exterior e estimular a cooperação cultural em esfera internacional, de modo a transmitir uma visão abrangente da Alemanha através de informações sobre a vida política, social e cultural do país. Uma das atuações do instituto se refere à premiação oficial Goethe Medaille, concedida a personalidades que, segundo divulgado no site da instituição, tem merecimento pela atuação na divulgação da língua alemã, assim como no intercâmbio cultural internacional. Esse prêmio foi recebido por Yoko Tawada em 2005.

No que se refere à atuação do Instituto Goethe no Brasil, o foco neste levantamento está no fomento às traduções de obras alemãs para o português do Brasil através do programa chamado de Translations of German Books into Other Languages (Tradução de Livros Alemães para Outras Línguas) ${ }^{22}$. Trata-se de um fomento de caráter internacional que dá suporte financeiro a editores não alemães que publicam literatura em língua alemã, com o objetivo de tornar acessíveis, aos que não leem alemão, trabalhos atuais de literatura contemporânea, literatura para crianças e jovens, títulos acadêmicos e trabalhos de não-ficção. O programa serve, ainda segundo a instituição, a uma política cultural e educacional internacional, de modo que Instituto arca com parte dos custos de tradução. O programa tem cerca de 40 anos de existência e fomentou aproximadamente 6000 livros em 45 línguas, segundo dados divulgados pelo Instituto Goethe ${ }^{23}$.

As condições para esse fomento específico são, resumidamente, que a obra tenha sido publicada por autores alemães em versão impressa por editora de língua alemã ${ }^{24}$. A tradução deve ser feita a partir do texto original em língua alemã e o tradutor necessita primeiramente conseguir a publicação junto a uma editora para

20 http://www.lcb.de/autoren/verlagsmetropolen/

$21 \mathrm{http}: / /$ www.goethe.de/ins/br/lp/uun/ptindex.htm

22http://www.goethe.de/kue/lit/prj/uef/enindex.htm. Consulta em 08.01.2016

23 https://www.goethe.de/ins/br/pt/kul/ser/uef.html

24"The Goethe-Institut supports the translation of works by German authors which have been published in print form by a German language publisher." IN: http://www.goethe.de/kue/lit/prj/uef/enindex.htm Consulta em 08.01.2016 
obter o fomento, o que dificulta traduções feitas no âmbito acadêmico. Nesse sentido, por seu caráter de pesquisa e educacional, as obras acadêmicas poderiam ser consideradas como relevantes dentro dos objetivos do Instituto para a concessão de tal fomento.

Com relação às obras cujas traduções para o português do Brasil receberam este fomento, expomos aqui um breve panorama. Na lista de obras fomentadas, segundo o levantamento que se inicia em 2002 e se estende até $2016{ }^{25}$, constam aproximadamente 190 títulos, sendo que quarenta obras foram escolhidas no âmbito do ano Brasil-Alemanha (2013-2014). Das traduções fomentadas, excluindo-se ensaios, textos sobre filosofia, sociologia, ou de caráter "técnico" em geral, aproximadamente 120 referem-se a obras de cunho literário ${ }^{26}$.

A partir de 2008 começam a ser traduzidas obras de autores, cuja origem linguística não é alemã ou que têm background de migração. Abaixo constam quatro desses autores, bem como as editoras que os publicaram no Brasil e seus tradutores. Ressaltamos que cada um deles teve a tradução de uma obra fomentada e acrescentamos aquelas obras que foram publicadas em português independentes do fomento.

Saša Stanišić recebeu o fomento em 2008, mesmo ano em que recebeu o prêmio Chamisso, e teve o livro Como o soldado conserta o gramofone publicado em 2009 pela editora Record, com tradução de Marcelo Backes. Já sem o fomento, em 2015, a editora Foz publica Antes da festa, do mesmo autor, também traduzido por Backes. A autora Arnica Esterl, por sua vez, recebeu o fomento em 2009, tendo seu livro As penas do dragão publicado em 2010 pela editora Cosac \& Naify, com tradução de Tércio Redondo. Esterl havia publicado em 2004, sem fomento, também pela Cosac \& Naify O alfaiate valente, tradução de Christine Röhrig e, em 2007, As mais belas histórias das Mil e uma Noites, tradução de Alexandre Flory.

Herta Müller teve seu livro Tudo que tenho levo comigo aprovado para o programa de fomento no ano seguinte ao recebimento do prêmio Nobel de

25 http://www.goethe.de/kue/lit/prj/uef/deindex.htm

26 O número é aproximado pois há publicações que geram discussão sobre seu "caráter" literário. Tal discussão extrapola o âmbito desta pesquisa. 
Literatura de 2009. A tradução é de Carola Saavedra Hurtado e foi publicado em 2011 pela Companhia das Letras. As outras obras da autora publicadas no Brasil foram: O Compromisso, tradução de Lya Luft (editora Globo, 2004) e Depressões, tradução de Ingrid Ani Assmann (editora Globo, 2010). Outra autora que participa deste programa de fomento é Terézia Mora, que recebeu o prêmio Chamisso em 2010. Seu livro Alle Tage foi escolhido no âmbito do "Ano da Alemanha no Brasil 2013-2014", mas as informações sobre sua tradução e publicação ainda não haviam sido divulgadas até o presente levantamento.

Tendo em vista este primeiro grupo de agentes exposto, apresentamos a seguir o segundo grupo considerado no âmbito deste trabalho que engloba editoras relevantes no âmbito da publicação de obras literárias em língua alemã. Este levantamento inicial tem seu foco na publicação de obras escritas por autores de origem linguística não alemã ou aqueles categorizados com o conceito de "Migrationsliteratur" (Literatura de Migração). Dentre esses autores, considero o universo apresentado pela bibliografia reunida em trabalho de 2013 feito pela Pädagogische Hochschule Karlsruhe (Escola Superior de Pedagogia Karlsruhe), com 84 escritores, cuja origem remete a países como Turquia, Líbano, Itália, Hungria, Chile, Síria, Japão, Bósnia, Bulgária, entre outros ${ }^{27}$.

As maiores editoras alemãs em termos de faturamento estão vinculadas a publicações de caráter científico ou têm seu aporte financeiro principal proveniente da publicação de livros didáticos e demais materiais deste tipo. No caso da publicação de obras literárias, há, na Alemanha, as editoras chamadas de "Publikumsverlage" (editoras que possuem normas específicas para o custeio das publicações). As formas de financiamento e as políticas voltadas ao pagamento de honorários para os autores extrapolam o espaço deste trabalho, mas são elementos importantes no âmbito da publicação de obras literárias na Alemanha.

27 Heidi Rösch unter Mitarbeit von Yvonne Anzt (Stand: April 2013): Bibliografie deutschsprachige Migrationsliteratur mit Kurzporträts. Pädagogischen Hochschule Karlsruhe. Disponível em: http://www.ph-karlsruhe.de/fileadmin/user_upload/hochschule/masterstudimm/ML-Biblio.pdf 
Um ranking de $2009{ }^{28}$ baseado no faturamento das editoras mostra que entre as 100 primeiras, 50 estão voltadas à área de literatura e livros de especialidade. E, entre essas editoras, o posicionamento das 14 primeiras se dá na ordem apresentada na tabela abaixo onde estão elencados os autores cujas obras foram publicadas por uma ou mais editoras:

\begin{tabular}{|l|l|}
\hline \multicolumn{1}{|c|}{ Editoras $^{29}$} & \multicolumn{1}{c|}{ Autores $^{\mathbf{3 0}}$} \\
\hline Random House & Wladimir Kaminer (Random Haus Audio) \\
\hline Rowohlt & $\begin{array}{l}\text { Ghazi Abdel-Quadir, Franco Biondi, Zoran Drvenkar, Osman } \\
\text { Engin, Anatol Feid, Terézia Mora, Herta Müller }\end{array}$ \\
\hline S.Fischer & $\begin{array}{l}\text { Jiri Gruša, Aras Ören, Aysel Özakin, Jakovos Papadopoulos, } \\
\text { Yüksel Pazarkaya, Akif Pirinçci, Said, Suleman Taufiq, Rafik } \\
\text { Schami, Feridun Zaimoglu, Rumjana Zacharieva, Ota Filip. }\end{array}$ \\
\hline Droemer Knaur & Selim Özdogan \\
\hline Lübbe & Zoran Drvenkar \\
\hline Oetinger-Gruppe & $\begin{array}{l}\text { Sinasi Dikmen, Dante Andrea Franzetti, Jiri Gruša, Radek } \\
\text { Knapp, Antonio Skarmeta, Carmine Abate, Güney Dal. }\end{array}$ \\
\hline Piper/Malik & Zoran Drvenkar, Suleman Taufik, Ghazi Abdel-Quadir. \\
\hline Carlsen & $\begin{array}{l}\text { Libuše Moníková, Suleman Taufik, Aras Ören, Franco Biondi, } \\
\text { Güney Dal, Osman Engin, Jasouf Naum, Rafik Schami, Vladimir } \\
\text { Vertlieb, Natascha Wodin }\end{array}$ \\
\hline Egmont Holding & \\
\hline $\begin{array}{l}\text { dtv } \\
\text { (Deutscher } \\
\text { Taschenbuch Verlag }\end{array}$ \\
\hline
\end{tabular}

$28 \mathrm{http}: / /$ www.buchreport.de/analysen/100_groesste_verlage.htm?no_cache=1

Última consulta em julho de 2016

29 Lista de editoras baseada no ranking por ordem do maior para o menor faturamento divulgado em 2009:

http://www.buchreport.de/nachrichten/verlage/verlage_nachricht/datum/2009/03/31/minus-aufdem-mainstream/pointer/nachrichten.htm

30 Considerado levantamento disponível em:

http://www.ph-karlsruhe.de/fileadmin/user_upload/hochschule/masterstudimm/ML-Biblio.pdf 


\begin{tabular}{|l|l|}
\hline Suhrkamp & $\begin{array}{l}\text { György Dalos, Radek Knapp, José Oliver, Yüksel Pazarkaya, } \\
\text { Ilma Rakusa, Alev Tekinay, Galsan Tschinag }\end{array}$ \\
\hline Ullstein & $\begin{array}{l}\text { Irena Vrkljan, Rumjana Zacharieva, Zoran Drvenkar, Jiri Gruša, } \\
\text { Yüksel Pazarkaya }\end{array}$ \\
\hline Diogenes & \\
\hline Langen Müller Herbig & Ota Filip \\
\hline
\end{tabular}

Como é possível observar, de uma lista de 84 escritores, 37 tiveram suas obras publicadas por pelo menos uma das 12 editoras - do total de 14 consideradas - perfazendo, assim, quase a metade do universo considerado de escritores. Se compararmos a posição ocupada pelos Gastarbeiter e sua "Literatura da Consternação" com a posição que ocupam vários dos "Migrantes-Literatos" atualmente é possível dizer que há um movimento de autores com origem linguístico-cultural não alemã em direção ao centro do sistema literário alemão. Franco Biondi e Rafik Schami, por exemplo, têm suas obras publicadas por editoras que estão no centro deste sistema.

Gostaria de retomar neste ponto uma entrevista de Tawada citada na seção 1.1, em que ela diz não achar que os Migrantes-Literatos sejam discriminados ou deixados à margem e fala de uma outra subdivisão que a incomoda: entre autoras e autores best-seller e não best-seller. Segundo GEISEL (2001) por ocasião de sua entrevista com Tawada:

Em sua prosa e em seus poemas, Yoko Tawada não escreve sobre o estrangeiro ela escreve de forma estrangeira. A lua anda nua de bicicleta pelo Parque da Metáfora; uma mulher sem calcanhares vem à Europa para a casa de seu marido que a tinha escolhido num catálogo e que aparece a ela somente em sonho. Essa poesia foge aos nossos modelos de significação e ela é, por isso, dificilmente vendável. "A mim bastam dois mil leitores», considera Tawada, que apesar de ofertas de editoras maiores se mantém fiel à Konkursbuchverlag von Claudia Gehrke, pois somente aqui ela tem certeza de que sua obra completa seja acompanhada. ${ }^{31}$

31 Este trecho consta em entrevista à Sieglinde Geisel (2001) publicada no site do jornal suíço Neue Zürcher Zeitung In: http://www.nzz.ch/article71HPS-1.468004: „In ihrer Prosa und den Gedichten jedoch schreibt Yoko Tawada nicht über das Fremde - sie schreibt fremd. Der nackte Mond fährt mit dem Fahrrad durch 
Uma parte central do sistema literário é, de fato, determinada por quem vende e quem não vende livros, mas as premiações e incentivos não se destinam somente aos best-sellers. Nesse contexto, é interessante notar que vários autores não publicados por grandes editoras também fazem parte de modo dinâmico do sistema literário alemão. No caso específico de Yoko Tawada, mesmo tendo sua obra publicada por uma editora de menor porte, é possível observar pelas premiações ${ }^{32}$, bolsas de incentivo, publicações e trabalhos sobre ela, que as forças que atuam nesse sistema literário estão distribuídas por agentes variados.

Alguns desses agentes foram expostos no decorrer desta seção justamente no intuito de apresentar um quadro mais abrangente do campo literário em que se insere a autora estudada. Em meio a esses agentes, destacamos, por fim, os que atuam na instituição universitária, sendo o tradutor-estudante um agente capaz de inovar a seleção de obras a serem traduzidas e também de mapear e de analisar criticamente as características principais do sistema em que estão inseridas.

Sendo assim, dado esse modesto panorama do subsistema literário em que se encontra Yoko Tawada, segue a seção 1.3 que trata especificamente de sua obra, sendo que o enfoque para revisitar alguns de seus trabalhos será dado pela presença do fremd.

den Metaphernpark; eine fersenlose Frau kommt nach Europa zu ihrem Mann, der sie sich aus einem Katalog ausgesucht hatte und ihr nur im Traum erscheint. Solche Poesie entzieht sich unseren Deutungsmustern, und sie ist entsprechend schwer verkäuflich. «Mir reichen zweitausend Leser», meint Yoko Tawada, die trotz Angeboten grosser Verlage dem Konkursbuchverlag von Claudia Gehrke die Treue hält, denn nur hier habe sie die Sicherheit, dass ihr gesamtes Werk begleitet werde."

32 A premiação mais recente conferida à Yoko Tawada foi o Kleist-Preis 2016, promovido pela Heinrich-von-Kleist-Gesellschaft, uma organização científica e literária.

Cf. Demais prêmios já recebidos por Tawada em: http://yokotawada.de/?page_id=5 


\subsection{A EXPERIÊNCIA COM E NO ESTRANGEIRO: O FREMD NA OBRA DE YOKO TAWADA}

Esta seção tem como objetivo revisitar a obra de Yoko Tawada a partir de três vertentes: ser estrangeiro e viver no estrangeiro; falar e escrever em língua estrangeira; e traduzir o estrangeiro. É possível notar essas vertentes trabalhadas literariamente nos textos da autora, em que se sobressaem os tópicos "língua" e "fremd", palavra que, conforme exposto na introdução deste trabalho, engloba ideias vinculadas a um caráter estranho, alheio e estrangeiro de algo ou alguém.

No período de 1987 a 2016 Yoko Tawada teve 23 livros publicados na Alemanha e 26 no Japão ${ }^{33}$. Alguns desses livros foram traduzidos para o inglês, francês e italiano, sendo que Ópio para Ovídio foi traduzido para o francês e para o japonês ${ }^{34}$. A autora publicou obras classificadas segundo gêneros variados como: ensaios literários, romances, escritos baseados em aulas poéticas, peças de teatro e poesia. Em entrevista, Tawada fala sobre essa divisão entre os gêneros:

Minhas peças de teatro provavelmente não são verdadeiras peças de teatro e meus poemas não são verdadeiros poemas e textos em prosa são como poemas e peças de teatro são como cartões postais. Eu tenho problemas com esses gêneros. São antes poemas em prosa, poéticos e fragmentados. ${ }^{35}$

No decorrer desta dissertação, as menções aos gêneros ocorrem esporadicamente para propiciar uma visão de sua produção literária e têm como fonte as informações que constam na bibliografia de Yoko Tawada divulgada no site oficial da autora ${ }^{36}$. As obras escolhidas no âmbito desta pesquisa contemplam

33 Cf.: http://yokotawada.de/?page_id=5

$34 \mathrm{http}: / /$ www.konkursbuch.com/html/yokoimages/uebersicht.html

35 Cf. in: http://www.foreigner.de/interviews/interview_yoko_tawada.html. Última consulta $14 / 11 / 2016$

„Meine Theaterstücke sind wahrscheinlich keine richtigen Theaterstücke und meine Gedichte sind keine richtigen Gedichte und Prosatexte sind wie Gedichte und die Theaterstücke sind wie Postkarten. Ich komme nicht klar mit diesen Gattungen. Das sind eher poetische, fragmentarische Prosagedichte."

36 Classificação de gênero contida na bibliografia divulgada no site da autora http://yokotawada.de/?page_id=5

Última consulta em 13/11/2016 
alguns dos ensaios literários contidos em Talisman (1996), Überseezungen (2002), Sprachpolizei e Spielpolyglotte (2007) e Akzentfrei (2016); além dos romances Das Bad (1989) e Das nackte Auge (2004). Trato ainda das aulas expositivas poéticas (Poetik-Vorlesungen) ministradas na Universidade de Tübingen no Curso de Inverno de 1997/1998, e compiladas no livro Verwandlungen (1998). ${ }^{37}$ Exponho, paralelamente, trechos de entrevistas concedidas pela autora em que ela explicita ideias vinculadas à sua visão de fremd.

Antes de nos atermos à obra de Tawada propriamente dita, considero relevante discorrer sobre alguns aspectos envolvidos na palavra fremd, que está presente em sua obra não somente como tema, mas também a partir da Fremdsprache (língua estrangeira), em si, na qual escreve seus textos, e de sua condição de estrangeira na Alemanha.

Uma questão com que nos deparamos no decorrer desta pesquisa foi como traduzir o termo fremd para o português. Ou, ainda, se deveria ser mantida a palavra na língua de partida, de modo a ecoar ela mesma como elemento alheio no texto em português. Por um lado, o termo em alemão poderia manter a multiplicidade de sentidos e não reduziria o seu espectro de significações. Por outro lado, haveria o risco de causar um estranhamento excessivo em algumas situações.

Diante disso, apresentamos um resumo de parte da definição do adjetivo fremd, segundo o dicionário Duden (2006): a primeira acepção se refere ao que não pertence a um país ou a um povo; aquele que apresenta outra origem: países estrangeiros, costumes estrangeiros, uma moeda estrangeira, aprender línguas estrangeiras. Em seguida, tem-se a acepção referente ao que pertence a outro ou faz referência a um outro, em contraposição à própria pessoa, como por exemplo: propriedade alheia; conseguir algo sem ajuda alheia (dos outros).

Outro significado qualifica, ainda, o desconhecido; não confiável: uma pessoa estranha; ter que viver em arredores estranhos; sentir-se desconhecido/estranho em algum lugar, de modo a não se encontrar, não se

37 Opto por não propor uma tradução para os títulos neste momento, mas sim mais adiante, ao apresentar alguns trechos das referidas obras. 
reconhecer, não saber de nada em determinado contexto; ou tornar-se estranho para o outro, no sentido de não se entender mais com alguém. $E$, por fim, tem-se a ideia do incomum, que não condiz com a expectativa de uma pessoa sobre algo ou alguém; ser de outra maneira. ${ }^{38}$

Ao longo deste trabalho utilizamos as diferentes variantes em português, conforme o contexto, seja ele relacionado às acepções de uma pessoa proveniente de outro país, considerada, portanto, estrangeira ou a alguém tido como o Outro, o alheio. Utilizamos, ainda, a palavra "estranho", no que se refere ao não conhecido ou ao incomum. Quando a multiplicidade de sentidos da palavra fremd parece ser relevante ao contexto, mantemos o termo em alemão. Também foi mantido o termo na língua de partida, quando Tawada discorre sobre ele, demonstrando o seu entendimento a esse respeito.

Yoko Tawada trata em vários de seus livros sobre uma língua e uma cultura alheias, de modo que o fremd é uma constante em seus textos, onde encontramos questões voltadas à autoria e ao processo de escrita, além da comparação entre culturas. Segundo ela, ser fremd mesmo dentro da própria cultura seria uma máxima necessária para os autores, conforme diz na entrevista Fremdsein ist eine Kunst (Ser fremd é uma arte), da qual retiramos as seguintes reflexões de Tawada sobre o fremd:

38 Abaixo está transcrita a descrição completa do adjetivo fremd conforme consta no dicionário Duden (2006) mencionado:

fremd \& <Adj. $>$ [mhd. vrem(e)de, ahd. fremidi, zu einem untergegangenen Adv. mit der Bed. "vorwärts; von - weg" (verw. mit ver-) u. eigtl. = entfernt]:

1. nicht dem eigenen Land od. Volk angehörend; von anderer Herkunft: -e Länder, Sitten; eine -e Währung; -e Sprachen lernen.

2. einem anderen gehörend; einen anderen, nicht die eigene Person, den eigenen Besitz betreffend: -es Eigentum; etw. ohne -e Hilfe schaffen; das ist nicht für -e Ohren bestimmt.

3. a) unbekannt; nicht vertraut: -e Leute; in -er Umgebung leben müssen; Verstellung ist ihr f. (sie kann sich nicht verstellen); ich fühle mich hier f. (kann mich hier nicht einleben); ich bin f. hier (kenne mich hier nicht aus, weiß hier nicht Bescheid); sie sind einander f. geworden (verstehen sich nicht mehr);

b) ungewohnt; nicht zu der Vorstellung, die jmd. von jmdm., etw. hat, passend; anders geartet: das ist ein -er Zug an ihr. 
Ser fremd tem, então, por assim dizer, um significado positivo ou é a atitude que se assume ou se tem conscientemente. Senão, ficar fremd significa muitas vezes, que alguém não conseguiu se integrar. Eu não acho isso. Ser fremd é uma arte. Não se é necessariamente fremd, aliás, eu me sinto na verdade completamente em casa aqui. Mas o autor precisa sempre ser fremd, mesmo no próprio país, para que não sejamos uma parte cega do todo, para que tenhamos distância, para que possamos não estar de acordo ou sentir que é lógico, sempre podemos pensar que poderia ser de outra forma, isto é ser fremd (...). Eu só consegui aprender uma nova língua e uma nova cultura já adulta, porque eu tentei ser fremd. Tratase de encontrar uma língua que possa descrever as diferenças não somente entre culturas, mas também dentro de uma cultura e dentro de uma cabeça. Também a coisa própria se metamorfoseia, duas coisas entram uma na outra e se misturam, e não necessariamente de duas culturas, mas também às vezes de um único impossível ou maravilhoso modo de comportamento percebido por duas pessoas de maneira completamente distinta (...). Cada um precisa encontrar sua Fremdheit [estranheza, estrangeiridade], nós precisamos ser fremd, senão, não há integração numa sociedade, onde moram muitas pessoas diferentes"39

(TAWADA em entrevista a HORST, 2009: 84)

Como é possível perceber com as considerações de Yoko Tawada sobre o fremd, essa questão ultrapassa para ela o caráter de estrangeiridade dentro de uma cultura e ganha dimensões mais amplas, como as que englobam as diferentes formas de perceber um mesmo acontecimento ou as transformações ocorridas em cada indivíduo. Nesse contexto, um certo distanciamento é necessário para que as coisas não se naturalizem, para que seja possível imaginar outras formas possíveis. A autora afirma, ainda, que integração não significa necessariamente assimilação, na medida em que se trata de achar uma língua que descreva as diferenças e, nesse sentido, não tente apagá-las em prol de uma pretensa homogeneização.

39 „Fremdsein ist dann sozusagen positiv gemeint oder die Haltung, die man dann behält, bewusst einnimmt. Sonst heißt fremd bleiben ja oft, jemand hat es nicht geschafft, sich zu integrieren. Das meine ich nicht. Fremd sein ist eine Kunst. Man ist ja nicht unbedingt fremd, eigentlich fühle ich mich ganz zu Hause hier. Aber das Fremd sein braucht der Autor immer, auch im eigenen Land, dass man nicht ein blinder Teil von einem Ganzen ist, dass man Distanz hat, dass man nicht einverstanden sein kann oder selbstverständlich empfindet, dass man immer denken kann, es könnte anders sein, das ist fremd sein. (...) Ich konnte nur deshalb eine neue Sprache und eine neue Kultur als Erwachsene lernen, weil ich versucht habe, fremd zu sein. Es geht darum, eine Sprache zu finden, die die Differenzen beschreiben kann und zwar nicht nur die zwischen Kulturen, sondern auch die innerhalb von einer Kultur und innerhalb von einem Kopf. Auch die eigene Sache verwandelt sich, zwei Sachen gehen ineinander und vermischen sich, und zwar nicht unbedingt aus zwei Kulturen, sondern auch manchmal aus einer einzigen unmöglichen oder wunderbaren Verhaltensweise, die von zwei Menschen ganz anders wahrgenommen wird (...) Jeder muss seine Fremdheit finden, entdecken, wir müssen fremd sein, sonst gibt es keine Integration in einer Gesellschaft, wo viele verschiedene Menschen leben.“ 
Sendo assim, Tawada ressalta a necessidade de manter o caráter estranho e estrangeiro de si e do texto, de modo que sua constituição está intimamente ligada às ideias de transformação e alteridade.

Dessa forma, poderíamos dizer que ser fremd permite habitar a diferença, de si mesmo e do Outro, mas esse conceito está permeado de significações e pode implicar, ainda, um sentimento de não adequação, de não pertencimento ou um distanciamento em relação a uma língua e a uma cultura ou ao sentimento de que se é alheio em seu próprio meio linguístico-cultural. Segundo ASSMANN (2011: 232):

Quanto de próprio, quanto de fremd o ser humano necessita? Nós ouvimos hoje não somente as vozes de autores pós-modernos, que anunciam uma nova época da transculturalidade, em que domina uma mistura global de raças, culturas, mídias e formas de vida e em que não há mais o estritamente fremd e o estritamente próprio (Welsch 1994). Nós ouvimos também as vozes dos fundamentalistas. E ouvimos as vozes dos autores pós-colonialistas, que depois de uma longa história de opressão e aniquilamento, partem para a busca por suas próprias culturas e reinventam suas tradições próprias. Nosso mundo continua a crescer tanto em homogeneização, quanto em diferenciação: fronteiras são constantemente permeadas e destruídas, mas em algum outro lugar também são erguidas novas. ${ }^{40}$

Conforme ASSMAN (2011:233), sobretudo os artistas que fizeram uma experiência migratória ou que se ocupam com uma consciente arqueologia das complexas camadas de suas memórias culturais são capazes de transmitir novas orientações através de tradições culturais. Nesse sentido, outro ponto levantado por ASSMAN refere-se às "identidades múltiplas" (multiple Identitäten). Ela afirma que "quanto mais a consciência controladora de um ser humano se dissolve e a fachada de sua autoencenação se torna quebradiça, mais espaço é aberto para a experiência da alteridade e da não identidade." ${ }^{41}$ (ASSMANN, 2011:22).

\footnotetext{
40,,Wieviel Eigenes, wie viel Fremdes braucht der Mensch? Wir hören heute nicht nur die Stimmen postmoderner Autoren, die eine neue Epoche der Transkulturalität ausrufen, in der eine globale Durchmischung der Rassen, Kulturen, Medien und Lebensformen herrscht und in der es 'kein strikt Fremdes und kein strikt Eigenes mehr gibt (Welsch 1994)'.Wir hören auch die Stimmen der Fundamentalisten . Und hören die Stimmen postkolonialer Autoren, die sich nach einer langen Geschichte der Unterdrückung und Vernichtung auf die Suche nach ihren eigenen Kulturen begeben und die Erfindung eigener Traditionen machen. Unsere Welt nimmt weiterhin an Homogenisierung wie an Differenzierung zu: Grenzen werden permanent durchlässig und abgebaut, aber woanders auch neu aufgerichtet.” .
}

41 „Je mehr sich das kontrollierende Bewusstsein eines Menschen auflöst und die Fassade seiner 
O ultrapassar das fronteiras certamente influencia a formação da identidade multifacetada de escritores como Yoko Tawada e a elaboração estética de suas obras. Tawada aponta para indícios de que a sociedade ocidental precisar parar de perseguir uma identidade duradoura, permanente, e diz que a "pretensão na Europa é que um ser humano, uma coisa ou uma cultura deva ter uma identidade durável. Por isso também se fala aqui "da cultura alemã" ou "da cultura japonesa"42 (TAWADA em entrevista a HORST, 2009: 84). Tawada deixa transparecer sua identidade fluida, como expõe ela mesma através da metáfora do "eu" enquanto água, descrita na seção 1.1, de modo que sua multiplicidade identitária cultural se dá em grande medida pelo fato de ela viver no estrangeiro e de falar e escrever em uma língua estrangeira.

Seu instrumento de comunicação e de trabalho apresenta uma dimensão alheia ao ventre da língua materna, portanto, não está em princípio intrínseca e "naturalizada". O trecho abaixo denota o uso que a autora faz dessa estranheza. Ela cria através dos chamados desvios da norma padrão textos poéticos e questiona os padrões ao desvelar um caráter estranho da língua, conferindo a ela novas paisagens. No ensaio literário akzentfrei (sem sotaque), lê-se:

Não é minha tarefa diferenciar um tom regional, de um sotaque estrangeiro, de um sociodialeto, de um distúrbio médico na fala. Ao invés disso, eu sugiro observar cada desvio como uma chance para a poesia. Me parece estranho falar sobre um "desvio", pois não tenho certeza se o "standard"sequer existe. Nas aulas de língua no Japão, aprendi que o alto alemão mais puro seria encontrado em Hanover, num palco de teatro e não num lugar qualquer na rua. Mas não há ninguém que nasceu num teatro de Hanover e nunca saiu do edifício do teatro. Desse modo, não há ninguém sem sotaque, assim como não há ninguém sem rugas no rosto. $O$ sotaque é o rosto da língua falada e suas rugas ao redor dos olhos e na testa desenham a cada segundo uma paisagem nova. (TAWADA, 2016) ${ }^{43}$

Selbst-Inzenierung brüchig wird, desto mehr Raum wird geschaffen für die Erfahrung von Alterität und Nicht-Identität"

42,,Der Anspruch in Europa ist, dass ein Mensch, ein Ding oder eine Kultur eine haltbare Identität haben muss. Deshalb spricht man hier auch von "der deutschen Kultur" oder "der japanischen Kultur"

43,Es ist nicht meine Aufgabe, eine regionale Färbung, einen ausländischen Akzent, einen Soziolekt und einen Sprachfehler medizinischer Art voneinander zu unterscheiden. Stattdessen schlage ich vor, jede Abweichung als eine Chance für die Poesie wahrzunehmen. Es kommt mir komisch vor, dass ich von einer „Abweichung" spreche, denn, ich bin nicht sicher, ob es überhaupt den „Standard“ gibt. Im Sprachunterricht in Japan habe ich gelernt, dass das reinste Hochdeutsch in Hannover zu finden sei, und zwar auf einer Theaterbühne und nicht irgendwo auf der Straße. Aber es gibt keinen Menschen, der in einem Hannoveraner Theater geboren wurde und nie das Theatergebäude verlassen hat. Also gibt es keinen Menschen ohne Akzent, so wie es keinen Menschen ohne Falten 
Em Verwandlungen (Metamorfoses), no capítulo Stimme eines Vogels (voz de um pássaro), Tawada se refere às características de uma língua estrangeira, e diz como se sente ao falar com e em uma língua estrangeira:

O ritmo da língua que continua a viver na língua estrangeira e a deforma - também chamado de 'sotaque' -, contém a lembrança do ventre da língua materna. Por outro lado, um idioma ganha às vezes uma certa corporeidade, quando é falado por uma língua estrangeira. ${ }^{44}$ (TAWADA, 1998:9)

Quando eu falo alemão, me imagino às vezes como uma compositora, que está numa floresta e tenta ouvir, anotar e imitar a música dos pássaros. Quem fala com uma língua estrangeira é um ornitólogo e um pássaro em uma pessoa. ${ }^{45}$ (TAWADA, 1998:22).

Nota-se nos trechos acima a dimensão corpórea da língua, de modo que a autora se utiliza das palavras Sprache (língua, enquanto linguagem e idioma) e Zunge (língua, a parte do corpo). Ao final do primeiro trecho, aparecem essas duas ideias: "(...) um idioma [Sprache] ganha às vezes uma certa corporeidade, quando é falado por uma língua [Zunge] estrangeira". Por isso, opto por pela palavra idioma para traduzir Sprache e diferenciar essa ocorrência de língua (Zunge), que também aparece no segundo trecho: "Quem fala com uma língua [Zunge] estrangeira é um ornitólogo e um pássaro em uma pessoa".

Essa questão que envolve a língua como a parte do corpo capaz produzir a a linguagem, por assim dizer, representa, como descrito na seção 1.1, certo caráter de "materialidade" da língua, segundo a visão de Tawada. Na passagem acima, uma corporeidade é conquistada pela linguagem devido a características agregadas a ela pelo falante de uma língua estrangeira. É interessante notar essa

im Gesicht gibt. Der Akzent ist das Gesicht der gesprochenen Sprache, und ihre Falten um die Augen und in der Stirn zeichnen jede Sekunde eine neue Landschaft.

in: http://www.konkursbuch.com/html/net\%202016/herbst\%2016/yoko\%20akzentfrei.pdf.

Última consulta em 14/11/2016.

44 „Der Sprachrythmus, der in der Fremdsprache weiterlebt und sie entstellt - man bezeichnet inn auch als 'Akzent' -, enthält die Erinnerung an den Leib der Muttersprache. Umgekehrt gewinnt eine Sprache manchmal eine Art Körperlichkeit, wenn sie von einer fremden Zunge gesprochen wird."

45,Wenn ich deutsch spreche, komme ich mir manchmal vor wie eine Komponistin, die in einen Wald steht und versucht, die Musik der Vögel zu hören, zu notieren und nachzuahmen. Wer mit einer fremden Zunge spricht, ist ein Ornithologe und ein Vogel in einer Person.“ 
visão não purista de um idioma, de modo que a junção dessas duas memórias linguísticas, a materna e a estrangeira, são capazes de gerar algo novo, uma língua outra.

Para Yoko Tawada as dimensões de estrangeiridade e estranheza estão presentes não somente na língua falada, mas também no sistema de escrita alfabética. Ainda em Verwandlungen (Metamorfoses) ela descreve essa relação com o alfabeto:

É uma arte ler o alfabeto. Há pouco tempo, percebi de repente que não consigo ler um livro alemão. Quanto mais eu me ocupo com a língua alemã, mais dificuldades me aparecem diante dos olhos. Mas eu já me acostumei com isso. As dificuldades lançam luz sobre o corpo da língua e desta maneira o fazem visível. Contrariamente, ficamos na maioria das vezes cegos em relação a algo que dominamos. ${ }^{46}$ (TAWADA, 1998:25)

Há uma pergunta apreciada sobre a língua no sonho: "Em que língua você sonha?" Mas não há nada de especial em se falar uma língua estrangeira no sonho. A língua falada pode se enfiar rápida na boca e voltar a saltar dela. Não é necessário incorporar uma língua para conseguir usá-la num sonho. A escrita, ao contrário, precisa de um tempo longo até se instalar no corpo. Ela se instala mais profunda, quase ilegível. (...) eu gostaria de formular a pergunta sobre a língua no sonho de outra maneira a uma sonhadora estrangeira. Minha pergunta seria: "Em qual escrita você sonha?" 47 (TAWADA, 1998:39)

Novamente Yoko Tawada ressalta o fato de ficarmos cegos em relação a algo que dominamos e, nesse sentido, utiliza a distância em relação ao alemão como um instrumento criativo, como uma luz no corpo da língua com a qual escreve seus textos. Diversas passagens dos ensaios literários de Talisman e de Überseezungen trabalham com a estranheza e certo distanciamento em relação à língua alemã, tanto no que se refere à sua expressão escrita, como a falada. $\mathrm{Na}$

46,Es ist eine Kunst, das Alphabet zu lesen. Vor kurzem stellte ich plötzlich fest, dass ich kein deutsches Buch lesen kann. Je länger ich mich mit der deutschen Sprache beschäftigt, desto mehr Schwierigkeiten fallen mir ins Auge. Aber daran habe ich mich schon gewöhnt. Die Schwierigkeiten werfen Licht auf den Sprachkörper und machen ihn auf diese Weise sichtbar. Dagegen bleibt man meistens blind in einer Sache, die man beherrscht."

47 „Es gibt eine beliebte Frage zur Sprache im Traum: “In welcher Sprache träumen Sie?” Es ist aber nichts Besonderes, wenn man im Traum eine fremde Sprache spricht. Die gesprochene Sprache kann schnell in den Mund hineinschlüpfen und wieder aus ihm herausspringen. Man muss sich eine Sprache nicht einverleiben, um sie in einem Traum verwenden zu können. Die Schrift hingegen braucht lange, bis sie im Körper sitzt. Sie sitzt tiefer, fast unlesbar. (...) ich würde gern an eine träumende Fremde gestellte Frage nach der Sprache in Traum anders formulieren. Meine Frage würde lauten: „In welcher Schrift träumen Sie?“ 
narrativa de Talisman Von der Muttersprache zur Sprachmutter (Da Língua-Mãe para a Mãe-Língua) há questões que envolvem o fato de que empiricamente um "lápis" em alemão ou em japonês não são distintos, mas como são formulados e caracterizados linguisticamente? Em certo momento, a narradora dessa história descreve uma situação em um escritório onde alguém profere xingamentos contra um lápis que não quer escrever:

\begin{abstract}
“O lápis idiota! Ele está louco! Ele não quer escrever hoje!” (...) Na língua japonesa não se pode personificar um lápis dessa forma. Um lápis não pode ser idiota ou tampouco enlouquecer(...). Independentemente se pela quebra constante do grafite do lápis ou pela falta de criatividade, toda pessoa fica desesperada, quando de repente não consegue continuar a escrever. Ela precisa restabelecer sua posição como escrevente ao xingar a sua ferramenta muda de escrita. Infelizmente não se trata aqui de animismo." 48 (TAWADA, 2008:11)
\end{abstract}

O texto Von der Muttersprache zur Sprachmutter (Da Língua-Mãe para a Mãe-Língua), assim como outros ensaios de Tawada, levantam questões voltadas à relação das pessoas com a língua, e esta, como no trecho acima, é representada pelo seu poder. A língua exerce, assim, sua posição de força em relação ao objeto, de modo que o falante, o escritor, o narrador e o autor a utilizam como instrumento de poder.

Esse aspecto da escrita é um dos temas constituintes das personagens criadas por Tawada, inclusive no que se refere a Ópio para Ovídio. O próximo capítulo trata especificamente desta obra, mas gostaria de notar de antemão que, neste livro, há personagens escritoras, linguistas, além da referência ao autor Ovídio, expressa no título, assim como a obra Livro do Travesseiro, de Sei Shônagon. No caso de Shônagon, é representativo o papel que a escrita exercia na dinâmica da corte japonesa de sua época. Também no próximo capítulo, tratamos mais especificamente das questões vinculadas ao intertexto e, portanto,

\footnotetext{
48, < Der blöde Bleistift! Der Spinnt! Der will heute nicht schreiben !> (...) In der japanisch Sprache kann man einen Bleistift nicht auf dieser Weise personifizieren. Ein Bleistift kann weder blöd sein noch spinnen.(TAWADA, 2008:10). (...) Unabhängig davon, ob es an der ständig brechenden Bleistiftmine liegt oder an der mangelnden Kreativität, wird jeder Mensch verzweifelt, wenn er plötzlich nicht weiterschreiben kann. Er muß seine Position als Schreibender wiederherstellen, indem er über sein stummes Schreibzeug schimpft. Leider handelt es sich hier nicht um einem Animismus." (TAWADA, 2008:10)
} 
aos dois autores citados. Por ora, ressaltamos apenas que, no caso do livro traduzido, temos um Ovídio dopado, cujo estado de torpor conferido pelo ópio é um dos indícios das múltiplas possibilidades de significações.

Nesse sentido, um dos processos a serem destacados no trabalho de Tawada é a demontage, capaz de explicitar a língua geradora de estruturas e significados de diversas dimensões. Esse processo pode ser observado no título do livro Überseezungen. Essa (des)montagem de palavras e significados mostra a sobreposição dos seguintes sentidos: Übersee (além-mar), Zungen (línguas, a parte do corpo) e Übersetzung (tradução). A palavra gerada com a sobreposição nos remete, ainda, aos verbos übersetzen (com a tônica no "se" e não separável; que significa traduzir) e ao übersetzen (verbo separável, com a tônica no “ü”; que significa atravessar de uma margem à outra).

O atravessar de uma margem a outra, no caso da tradução, provoca a inversão de perspectivas, um deslocamento, mas, segundo a concepção de Yoko Tawada, não deve anular o caráter estrangeiro do texto, como veremos mais adiante ainda nesta seção. Na obra desta escritora, a múltipla atribuição de significados parece estar vinculada também à dimensão de estranheza que uma língua e uma cultura podem revelar, assim como as pontes criadas entre o alheio e o próprio. Exemplifico essa dimensão com trechos da história Das Fremde aus der Dose (O Fremde da lata), contida no livro Talisman.

\begin{abstract}
Não somente $o\langle S\rangle$, mas também as outras letras do alfabeto não tinham, ao contrário de uma cobra viva, nem carne, nem umidade. Eu repeti o som $\mathrm{S}$ na boca e nisso percebi que, de repente, minha língua tinha sabor de fremd. Eu não sabia, até então, que a língua também podia ter gosto de alguma coisa. (...) É curioso, que uma expressão fremd do rosto é frequentemente comparada com uma máscara. Essa comparação tem por base o desejo de descobrir atrás de um rosto fremd, um conhecido? (...) Perguntas que começam com <também é assim no Japão, que ...> também eram frequentemente feitas a mim. Eu não conseguia respondê-las. Toda tentativa de descrever a diferença entre duas culturas dava errado: a diferença era passada diretamente sobre minha pele como uma escrita fremd, que eu até conseguia sentir, mas não ler. Cada som fremd, cada olhar fremd, cada gosto fremd produziam um efeito desagradável no corpo, até que o corpo se modificava. (TAWADA, 2008:40-42)" 49
\end{abstract}

49, Nicht nur das $\langle$ S $>$, sondern auch die anderen Buchstaben des Alphabets hatten im Unterschied zu einer lebenden Schlange weder Fleisch noch Feuchtigkeit. Ich wiederholte die S-Laute im Mund und merkte dabei, dass meine Zunge plötzlich fremd schmeckte. Ich wusste bis dahin nicht, dass die Zunge auch nach etwas schmecken konnte. (...) Es ist merkwürdig, dass ein fremder 
Yoko Tawada mostra em sua obra as diferentes significações atribuídas a um mesmo objeto, personagem ou acontecimento. As perspectivas da realidade de seu mundo ficcional são sempre invertidas, revertidas e reinventadas pelo torpor, pelas transformações e metamorfoses, pela máscara colocada no outro e pela criação literária de escritoras-personagens. A modificação física em si transparece nas transformações que se materializam pelo contato com o estrangeiro. Na citação acima, é possível perceber que tal contato provoca efeitos desagradáveis até que o corpo se modifica. O sabor do estranho, a percepção do estrangeiro pela e na própria língua é uma constante nos textos da autora. Além disso, há a dimensão cultural, perpassada também pela escrita estrangeira, que a narradora sente, mas não consegue "ler".

Neste contato com o alheio, são impressas feições nas faces dos estrangeiros. Tais feições são baseadas nos modelos de significação que usamos para tentar apreender o mundo, partindo do conhecido e de uma interpretação própria do Outro. Desta forma, o olhar imprime características interpretadas no rosto estranho, como uma forma de reconhecê-lo e de marcá-lo. Em seu livro Verwandlungen (Metamorfoses), no capitulo "Gesicht eines Fisches oder das Problem der Verwandlung " (Rosto de um peixe ou o problema da metamorfose), Tawada diz:

Quase não é possível evitar o tema do rosto, quando nos ocupamos com a estrangeiridade. Por isso, viajantes recebem dos nativos tantas máscaras calcadas no rosto, pois senão permanecem invisíveis. Há uma cena em minha narrativa 'Das Bad' [O Banho], na qual a narradora em primeira pessoa volta ao Japão depois de uma longa estadia na Europa. A mãe olha admirada para ela e pergunta:

"Por que você adquiriu um rosto tão asiático?"

A narradora em primeira pessoa responde:

"O que você está falando é absurdo, mãe. Isso é óbvio. Eu sou uma asiática."

Ao que a mãe diz:

Gesichtsausdruck oft mit einer Maske verglichen wird. Liegt diesem Vergleich der Wunsch zugrunde, hinter dem fremden Gesicht ein bekanntes zu entdecken? (...) Fragen, die mit < ist es in Japan auch so, dass... > anfangen, wurden mir auch oft gestellt. Ich konnte sie nicht beantworten. Jeder Versuch, den Unterschied zwischen zwei Kulturen zu beschreiben, misslang mir: Der Unterschied wurde direkt auf meine Haut aufgetragen wie eine fremde Schrift, die ich zwar spüren, aber nicht lesen konnte. Jeder fremde Klang, jeder fremde Blick und jeder fremde Geschmack wirkten unangenehmen auf den Körper, so lange, bis der Körper sich veränderte." 
Eu não quis dizer isso. Você adquiriu um rosto estrangeiro; como os japoneses que aparecem nos filmes americanos. ${ }^{50}$ (TAWADA, 1998:52)

Ao estrangeiro são atribuídas máscaras cravadas de significações a partir das mais diversas perspectivas culturais, subjetivas, linguísticas. Assim, depreende-se o estranho, lapidando o mesmo segundo algum universo conhecido. O peculiar do universo ficcional de Tawada é a expansão das perspectivas possíveis em que o trivial é ser estranho, é viver na diferença e no sabor do estrangeiro sentido pela língua e expresso por sua fala e sua escrita.

As máscaras são impressas não somente no estrangeiro, mas por ele mesmo, já que na condição de viajante em deslocamento modifica-se a si próprio em contato com o desconhecido. A transformação das feições, do corpo, assim como a água europeia durante a viagem de Tawada pela Transiberiana do Oriente para a Europa, denota a transformação lenta e gradual, segundo a autora em entrevista a SAALFELD (2002:186) citada na seção 1.1.

O tema da viagem, do ser estrangeira e viver no estrangeiro é recorrente em seus livros, em muitos dos quais as protagonistas são viajantes, estrangeiras, deslocadas, não estão em seu país de origem e lidam com culturas e línguas estrangeiras. No livro Das Bad (O banho), a protagonista estrangeira trabalha como intérprete. Com frequência, Yoko Tawada é perguntada em entrevistas se é possível dizer que seus livros têm algo de autobiográfico. Em uma das respostas sobre o tema, a autora diz referindo-se a Das Bad:

50 Man kann das Thema des Gesichts kaum umgehen, wenn man sich mit der Fremdheit beschäftigt. Reisenden bekommen von den Einheimischen deshalb so viele Masken aufs Gesicht gedrückt, weil sie sonst unsichtbar bleiben. Es gibt eine Szene in meiner Erzählung 'Das Bad', in der die Ich-Erzählerin nach einem langen Aufenthalt in Europa nach Japan zurück fährt. Die Mutter blickt sie verwundet an und fragt:

„Warum hast du so ein asiatisches Gesicht bekommen?“

Die Ich-Erzählerin antwortet:

„Du redest Unsinn, Mutter. Das ist doch selbstverständlich. Ich bin eine Asiatin.“

Darauf sagt die Mutter:

„So habe ich es nicht gemeint. Du hast ein fremdes Gesicht bekommen; wie die Japaner, die in amerikanischen Filmen auftreten." 
No que se refere ao sentimento sim. Mas eu não fui transformada em um peixe. Entretanto, no decorrer dos meus estudos em Hamburgo, trabalhei como intérprete e conheço sentimentos deste tipo, quando é necessário, por exemplo, gravar em si a língua das pessoas de negócios e falar a mesma com a própria boca. Eu conheço o sentimento de quando coisas que não gostaríamos de modo algum de dizer precisam sair continuamente pelo próprio corpo, o que é muito desagradável. ${ }^{51}$

A língua tem novamente aqui uma dimensão material, tátil, que não passa desapercebida pelo corpo e, mais especificamente, pela própria boca. Há uma metamorfose física, nos "estrangeirizamos" ou nos tornamos um pouco alheios a nós mesmos ao falar uma língua estrangeira. A viagem em si é um ambiente propício à transformação, por implicar deslocamento, alteração de perspectivas e o caminho para o encontro com a alteridade. A viagem, de certa forma, também pode ser um desvio, assim como os desvios linguísticos citados anteriormente, mas não deixam de ser parte dos deslocamentos, assim como os desvios da língua acabam também por constituí-la.

A viagem pela Transiberiana e os deslocamentos em geral são uma constante no romance Das nackte Auge (O olho nu), em que a personagem principal vai do Vietnã para Berlim Oriental, de lá para a Alemanha Ocidental e, em seguida, para Paris. Em alguns desses trechos ela vai obrigada, em outros, por engano. Chega a Paris, querendo chegar a Moscou. Um trecho do primeiro capítulo intitulado Repulsion ${ }^{52}$ :

Jörg falou de repente em russo, talvez por pena de mim. Ele perguntou à Anna, se ela sabia que o prolongamento da ferrovia Transiberiana passava por Bochum. Essa linha de trem teria ligado Moscou direto a Paris. A expressão do rosto de

51 „Vom Gefühl her schon. Aber ich bin nicht in einen Fisch verwandelt worden. Ich habe aber während meines Studiums in Hamburg als Dolmetscherin gearbeitet und kenne solche Gefühle: Dass man z.B. die Sprache der Geschäftsleute in sich aufnehmen muss und sie mit dem eigenen Mund aussprechen muss. Ich kenne das Gefühl, dass die Dinge, die man gar nicht sagen möchte, ständig durch den eigenen Körper durchgehen müssen, was sehr unangenehm ist."

Cf.Em:http://www.foreigner.de/interviews/interview_yoko_tawada.html.

Último acesso em 15/11/2016

52 Cada capítulo de das Nackte Auge faz referência a um filme. Repulsion, neste caso, refere-se ao filme de 1965, dirigido por Roman Polanski. 
Anna se iluminou de repente: "Sim, eu sei. Os trilhos passam pela Sete Planetas, acho eu" (...) Mais tarde perguntei novamente a Jörg, se o trem de Moscou a Paris teria de fato passado por Bochum. Jörg respondeu como um orgulhoso aluno da escola primária que é elogiado pelo professor: "Sim, com certeza. Do Oriente longínquo veio o trem. Ele deve ter cheirado a plantas marítimas do Pacífico, que havia na costa de Vladivostok ou a pedras da muralha da China, a areia do deserto mongólico, a água salgada do lago Baykal. O trem veio pelos Urais para Moscou e depois para Bochum, para continuar a viagem a Paris." 53 (TAWADA, 2004)

A relação entre as visões sobre o Ocidente e o Oriente também é uma constante na obra e nas reflexões de Yoko Tawada. Assim como os trilhos, a língua é apresentada como possibilidade de ultrapassar fronteiras entre o observador e o objeto e constituir uma travessia. Nesse sentido, ao falarmos uma língua estrangeira podemos sair de uma apreciação superficial para sentir o sabor da outra cultura. Em um dos ensaios do livro Talisman (Talismã), chamado Eigentlich darf man es niemandem sagen, aber Europa gibt es nicht (Na verdade não se pode dizer isso a ninguém, mas a Europa não existe), é possível perceber como a narradora evita tentar entender a Europa através de um imaginário preconcebido, no sentido das imagens propriamente ditas. Conforme o trecho abaixo, ela quer antes sentir a Europa com a língua - neste caso a parte do corpo (Zunge):

Poderíamos entender a Europa não apenas como uma personagem, mas também como uma soma de imagens. Eu poderia pegar alguns belos postais de minha coleção e dali formar um mundo imaginário. Mas não vou fazer isso, porque há o perigo de que o resultado seja uma mera inversão do Orientalismo. As imagens têm sempre - direta ou indiretamente - algo a ver com a percepção óptica. No entanto, não quero mais perceber a Europa opticamente, mas sim com minha língua. Se a minha língua sentir o sabor da Europa e falar Europa, eu

53 Trechos retirados do primeiro capítulo do livro "Das nackte Auge"disponível sem numeração de páginas no site da editora:

http://www.konkursbuch.com/html/netfr2004/yokoAugeKapitel\%201.htm (última consulta em 26/06/2016)

„Jörg sprach plötzlich russisch, wahrscheinlich aus Mitleid mit mir. Er fragte Anna, ob sie wisse, dass die Verlängerung der Transsibirischen Eisenbahn durch Bochum gefahren sei. Diese Eisenbahnlinie habe Moskau direkt mit Paris verbunden. Annas Gesichtsausdruck hellte sich plötzlich auf: "Ja, ich weiß. Die Schienen verliefen bei den Sieben Planeten, glaube ich." (...)Später fragte ich Jörg noch einmal, ob der Zug von Moskau nach Paris tatsächlich durch Bochum gefahren sei. Jörg antwortete wie ein stolzer Grundschüler, der von dem Lehrer gelobt wird: "Ja, sicher. Aus dem Fernen Osten kam der Zug. Er muss nach pazifischen Seepflanzen, die an der Küste von Vladivostok lagen, gerochen haben, oder nach den Steinen der Chinesischen Mauer, dem Sand der mongolischen Wüste, dem salzigen Wasser des Baykalsees. Der Zug kam über den Ural nach Moskau und dann nach Bochum, um weiter nach Paris zu fahren." 
poderia talvez ultrapassar as fronteiras entre observador e objeto. ${ }^{54}$ (TAWADA, 2008: 51)

Como dito anteriormente, a língua como parte do corpo (Zunge) parece representar essa dimensão física e palpável da língua enquanto idioma (Sprache). As transformações do corpo, as modificações, o sotaque como rugas na pele, o gosto do idioma na língua, a metamorfose gradual pela fala e pela escrita. Essa metamorfose não indica, porém, uma simples mistura ou assimilação. $O$ caráter fremd do ser alheio e estrangeiro permanece e as tensões entre o "Eu" e o "Outro" não cessam. Muros são constantemente construídos por uma ideia de pertencimento em contraponto à tentativa de apartar os considerados "de fora".

Exemplificamos essa questão com um trecho da narrativa "An der Spree" (À margem do Spree), um dos ensaios literários de Sprachpolizei und Spielpolyglotte (Polícia da língua e poliglota do jogo, em tradução livre), de TAWADA (2007):

\begin{abstract}
Alguém que tenha o passaporte norte-americano é um norte-americano, mas alguém que tenha o passaporte europeu não é necessariamente um europeu. Ou uma pessoa nasceu europeia ou alguma outra coisa. Não nos tornarmos posteriormente europeus. Por isso, nunca requeri um passaporte europeu. Então, o que faço com o policial que quer me proteger de roubo? "Eu não sou turista, eu moro aqui. Como se chamam as pessoas que moram na Europa?", perguntei a ele. "Eu não sei. Imigrantes?", me perguntou ele em dúvida. (...) O trem de subúrbio que corre na superfície para a Friedrichstraße chegou pontualmente. "Em nosso país o trem sempre chega pontualmente", me disse um senhor mais velho que estava perto de mim. Ele pensou com certeza que eu pertencia a um outro grupo de "NÓS", no país dos quais nenhum trem chega pontualmente. Uma mulher com cabelos curtos e vermelhos que estava à nossa frente, virou-se e revidou: "Isso não é verdade. Nossos trens sempre têm atrasos!" As portas se abriram. "Aonde?", eu perguntei. "Aonde eles chegam pontualmente e onde eles sempre têm atrasos?". Não houve resposta. As portas se fecharam automaticamente. 55
\end{abstract}

\begin{abstract}
54,,Man könnte Europa nicht nur als eine Figur, sondern auch als eine Summe von Bildern verstehen. Ich könnte einige schöne Postkarten aus meiner Sammlung herausnehmen und daraus eine imaginäre Welt bilden. Ich werde das aber nicht tun, weil die Gefahr besteht, dass das Ergebnis eine bloße Umkehrung des Orientalismus wäre. Die Bilder haben immer - direkt oder indirekt - mit der optischen Wahrnehmung zu tun. Ich möchte aber Europa nicht mehr optisch, sondern mit meiner Zunge wahrnehmen. Wenn meine Zunge Europa schmeckt und Europa spricht, könnte ich vielleicht die Grenze zwischen Betrachter und Objekt überschreiten."
\end{abstract}

55 In: http://www.konkursbuch.com/html/leseproben\%20net\%2007/leseprobe-tawada-sprachp.pdf

„Einer, der einen amerikanischen Pass hat, ist ein Amerikaner, aber einer, der einen europäischen Pass hat, ist nicht unbedingt ein Europäer. Ein Mensch ist entweder als Europäer oder als etwas 
Nesse parágrafo nota-se a contraposição entre o "nosso país" e o país dos outros. A narradora em primeira pessoa não se sente turista, mas também não se sente europeia e a categoria que ocorre ao policial, ao ser perguntado sobre como são chamadas as pessoas que moram a Europa, é a de "imigrantes". A delimitação nacional como suposta forma de homogeneidade se mostra controversa em si, já que no mesmo país em que há atrasos também há pontualidade.

As divergências entre os integrantes desse "nosso país" mostram que eles podem ser alheios também entre si. Onde fica o país em que há atrasos? No mesmo lugar em que não os há. A diferença predomina nos textos de Yoko Tawada, de modo que não parece haver intenção alguma de unificar, de tornar homogêneo. Pelo contrário, a autora realça constantemente as diferenças e a possibilidade de habitá-las, sem necessariamente delimitar fronteiras entre si.

O eu híbrido, para o qual os desvios fazem parte do caminho, está em constante deslocamento, seja numa viagem em direção ao outro ou às próprias transformações. Nesse sentido, é possível identificar um campo semântico que permeia vida e obra de Tawada que engloba, dentre outros termos, os seguintes: transiberiano, transculturalidade, transpor, transmitir, transmudar, transportar, transgredir, transcender, transformar. Esse campo semântico também é capaz de englobar a forma como a autora entende a tradução, sobre a qual Yoko Tawada expõe uma concepção vinculada à ideia de transformação. Segundo BLUME:

\begin{abstract}
Sobre a tradução dos seus próprios poemas pelo tradutor Peter Pörtner do japonês ao alemão, Tawada (1998, p. 7) comenta que, quando eles foram publicados, várias pessoas lhe perguntavam o que achava dessa tradução. Ela afirma que não via nessas traduções nenhuma perda, apesar de toda a diferença entre as línguas japonesa e alemã. "Naquele tempo encontrei a palavra transformação, para defender possibilidades criativas do trabalho de tradução [...]", diz a autora. E essa transformação também se daria entre mudanças de
\end{abstract}

anderes geboren. Man wird nicht nachträglich zu einem Europäer. Daher habe ich nie einen europäischen Pass beantragt. Also, was mache ich mit dem Polizisten, der mich vor Diebstahl schützen will? „Ich bin keine Touristin, ich wohne hier. Wie heißen die Menschen, die in Europa leben?", fragte ich inn. „Ich weiß nicht. Einwanderer?“, fragte er mich verunsichert.(...) Die S-Bahn nach Friedrichstraße kam pünktlich an. „Bei uns kommt der Zug immer pünktlich an“, sagte ein älterer Herr, der neben mir stand, zu mir. Er dachte sicher, ich würde zu einer anderen Gruppe von WIR gehören, bei denen kein Zug pünktlich ankommt. Eine Frau mit kurzen roten Haaren, die vor uns stand, drehte sich um und erwiderte: „Das stimmt nicht. Unsere Züge haben immer Verspätungen!“ Die Türen öffneten sich. „Wo?“, fragte ich. „Wo kommen sie pünktlich an und wo haben sie immer Verspätungen?" Es gab aber keine Antwort. Die Türen schlossen selbsttätig." 
gênero textual, como um texto em livro que vai para o palco, por exemplo. Ao contrário da palavra "perda" a palavra "transformação" não soa nem trágica nem dramática. Além disso, ela parece ser livre de um propósito limitado ou de um plano orientado para o lucro. Não se perdeu nada e não se sabe o que surgirá após uma transformação (TAWADA, 1998, p. 8). E poderíamos afirmar, também, que essa tradução como transformação não se dá, para a autora, somente nos processos interlinguísticos ou intertextuais, mas na própria identidade de quem migra (...). Essa visão da tradução como um constante processo de transformação aponta para a abolição de limites ou fronteiras rígidas em favor de uma maior fluidez entre as línguas e culturas, ideia essa muito presente no conjunto da obra de Tawada. (BLUME, 2014:69)

Na passagem acima, fica clara a noção que norteia a visão de Yoko Tawada sobre tradução: uma transformação pautada na liberdade, sem um propósito limitado ou orientado somente para o lucro. A autora nega, assim, qualquer ideia de perda e exalta o que pode surgir de novo com uma transposição linguísticocultural. Ainda sobre sua concepção de um processo tradutório, é importante frisar que o traduzir, segundo ela, implica uma transposição deformadora, e não conformadora. Yoko Tawada diz no livro Verwandlungen (Metamorfoses), no segundo capítulo intitulado Schrift einer Schildkröte oder das Problem der Übersetzung (Escrita de uma tartaruga ou o problema da tradução):

\begin{abstract}
Uma tradução literária precisa perseguir obsessivamente a literalidade até que a língua da tradução rompa as barreiras da estética convencional. Uma tradução literária deve partir da intraduzibilidade e lidar com ela, ao invés de eliminá-la. É fácil criticar uma tradução. Principalmente no que se refere a poemas modernos, leitores cultos e pretenciosos gostam de falar do desempenho deficiente dos tradutores. É frequentemente ignorada a forma como a tradução lida com a intraduzibilidade. Uma transposição interessante, uma deformação revigorante ou um deslocamento delirante para a língua própria é, antes, um feito da tradução. Por outro lado, é igualmente fácil elogiar uma tradução. Bocas triviais a elogiam quando a língua da tradução soa natural. A tradução faria o leitor esquecer que se trata de uma tradução. Este elogio revela uma lógica distorcida. Não se diz: esta literatura é boa, porque quase esquecemos que é literatura. Para mim, o fascínio de uma tradução está no fato de fazer com que o leitor sinta a existência de uma língua completamente diferente. A língua da tradução tateia cuidadosa a superfície do texto sem se fazer dependente de seu núcleo.
\end{abstract}

(TAWADA, 1998:35 e 36; grifos meus) ${ }^{56}$

56 „Eine literarische Übersetzung muß obsessiv der Wörtlichkeit nachgehen, bis die Sprache der Übersetzung die konventionelle Ästhetik sprengt. Eine literarische Übersetzung muß von der Unübersetzbarkeit ausgehen und mit ihr umgehen, statt sie zu beseitigen. Es ist einfach, eine Übersetzung zu kritisieren. Besonders bei modernen Gedichten sprechen gebildete und eingebildete Leser gerne über die die mangelhaft Leistung der Übersetzer. Dabei wird oft übersehen, wie wie die Übersetzung mit der Unübersetzbarkeit umgeht. Eine interessante Verschiebung, eine erfrischende 
É possivel observar pelas considerações acima os parâmetros relacionados à concepção de tradução por parte de Yoko Tawada. A literalidade (Wörtlichkeit), a lida com a intraduzibilidade (Unübersetzbarkeit) para conseguir uma transposição (Verschiebung), uma deformação (Entstellung) ou um deslocamento (Verrückung) para a língua alvo, são considerados resultados interessantes, revigorantes. Sob esse ponto de vista, o leitor teria contato com uma língua diferente, uma tradução que está ligada à superfície do texto de partida, mas não é dependente do seu núcleo.

Sendo assim, buscamos realizar um trabalho de tradução comentada coerente com o entendimento de Yoko Tawada sobre o traduzir, partindo do pressuposto de uma lida com a linguagem num espaço de provocação e de incômodo. Nesse sentido, perseguimos o propósito de evitar o achatamento da estrangeiridade do texto dessa escritora e, por fim, sem perder de vista a inteligibilidade, exercitamos um processo tradutório capaz de privilegiar a visibilidade do estrangeiro e do caráter do texto traduzido enquanto tal.

Por isso, abordamos no próximo capítulo a ideia de intertextualidade como memória em que o espaço da transição temporal e estética permite criar algo novo no presente. $O$ texto traduzido também se constitui nesse espaço e pode realizar em si essa transposição transformadora. Assim, o capítulo 2 visa a descrever a obra traduzida de modo a enfatizar o diálogo intertextual estabelecido por Yoko Tawada. Com esse propósito, apresentamos, a seguir, alguns aspectos da noção de intertextualidade que se coadunam com um caráter dinâmico da literatura, passível de promover múltiplas significações a cada leitura de um texto, inclusive as que se concretizam no texto-tradução.

Entstellung oder eine wahnhafte Verrückung in die eigene Sprache ist doch eher eine Leistung der Übersetzung. Andererseits ist es genauso einfach, eine Übersetzung zu loben. Triviale Münder loben sie, wenn die Sprache der Übersetzung natürlich klingt. Die Übersetzung lasse den Leser vergessen, daß eine Übersetzung sei. Dieses Lob zeugt von einer verdrehten Logik. Man sagt doch auch nicht: Diese Literatur ist gut, weil man fast vergißt, daß es Literatur ist. Für mich besteht der Reiz einer Übersetzung darin, daß sie den Leser die Existenz einer ganz anderen Sprache spüren läßt. Die Sprache der Übersetzung tastet die Oberfläche des Textes vorsichtig ab, ohne sich von seinem Kern abhängig zu machen." 


\section{Capítulo II}

\section{Ópio para Ovídio: sobre o texto e os intertextos}

Este capítulo consiste numa apresentação do livro Opium für Ovid: Ein Kopfkissenbuch von 22 Frauen (Ópio para Ovídio: um Livro do Travesseiro de 22 mulheres) e dos intertextos Metamorfoses, de Ovídio e o Livro do Travesseiro, de Sei Shônagon. A partir da análise de Ópio para Ovídio, especialmente dos dois textos traduzidos (Latona e Coronis), faz-se pertinente analisar o diálogo intertextual estabelecido por Yoko Tawada com foco na releitura dessas referências literárias milenares. Para tanto, é exposta a noção de intertextualidade considerada na leitura dessa obra, que implica a (re)invenção e a constante (re)construção da memória literária, inclusive no que se refere à tradução.

Ópio para Ovídio compõe-se de vinte e duas "mulheres-capítulos", cada uma intitulada com o nome de uma das personagens principais. Elas possuem, ao mesmo tempo, uma unidade de sentido em si mesmas e uma relação com as demais. Essa relação se dá de modo descontínuo e fragmentário, não havendo entre as partes uma ideia de sequência lógica ou linearidade. A classificação deste livro aparece na página oficial da autora como $\operatorname{prosa}^{57}$ e não como Roman (romance) ou Erzählungen (narrativas). Devido a esse aspecto e também ao fato de Yoko Tawada ressaltar, como explicitado mais adiante, a produção literária feita por mulheres, optamos pelo termo "mulheres-capítulos", ao invés de narrativas ou mesmo capítulos.

Conforme apresentamos na seção 1.3, Yoko Tawada não é afeita à categorização estrita de gêneros literários, de modo que a autora percebe em seus textos aspectos fluidos do que caracterizaria um texto como poesia ou teatro, por

57 Opium für Ovid. Ein Kopfkissenbuch von 22 Frauen. (Prosa) 2000 in:

http://yokotawada.de/?page_id=5 
exemplo. A escritora opta por "definir" Ópio para Ovídio ficcionalmente no título do livro como sendo um Livro do Travesseiro, cujas referências serão apresentadas mais adiante.

Alguns dos principais eixos temáticos que perpassam as vinte e duas mulheres da obra estudada são os seguintes: ópio, torpor, deslocamento, migração, não-identidade (identidades múltiplas), metamorfose e a ideia de transformação, Sucht e Sehnsucht (vício e saudade) e, por fim, a língua e a autoria.

Latona foi escolhida para exemplificar este exercício tradutório por abordar os temas mencionados de modo especialmente irônico, principalmente no que se refere a uma certa visão ocidental sobre o "Oriente", já Coronis, por trazer à tona a questão do não pertencimento nacional e por ser escritora. Esse último aspecto temático voltado à questão da língua e da autoria permeia a obra de Yoko Tawada, de modo que seus ensaios literários, alguns dos quais apresentamos na seção 1.3, têm relevância considerável em sua obra.

Quanto a Ópio para Ovídio, o trabalho com a língua e com o próprio tema da autoria, se dá em grande medida no diálogo com as referências voltadas ao poeta latino Ovídio e à obra japonesa de Sei Shônagon. Cabe ressaltar o que se entende aqui por referencialidade que se trata, segundo SAMOYAULT (2008:114), "do jogo da referência como lugar intermediário entre o texto e o mundo, encontrando seu sentido do lado de uma totalidade, que inclui um e outro."

Acreditamos ser importante, no âmbito deste trabalho, considerar alguns aspectos que permitam analisar o funcionamento do conceito de intertextualidade "de maneira unificada, reunindo seus traços em torno da ideia de memória" (SAMOYAULT, 2008:10). Assim, antes de nos atermos às obras literárias propriamente ditas, recorremos a SAMOYAULT (2008) para apresentar a noção de intertextualidade considerada neste trabalho. Inicialmente, ressaltamos que, segundo essa autora, faz-se necessário considerar a forma como a memória permite que a literatura "retenha uma história, que não obedece talvez às mesmas regras do mundo, mas que a tira de um imobilismo redutor" (SAMOYAULT, 2008:114).

Não cabe aqui discorrer sobre a teoria dos diversos autores fundamentais vinculados de alguma forma à noção de intertextualidade desde Julia Kristeva e o nascimento da palavra "intertextualidade", Bakhtin e o diálogo dos textos, além de 
Roland Barthes, Rifaterre e Gérard Genette. Vou me ater à proposta de SAMOYAULT e à sua ideia de intertextualidade no âmbito da relação dos textos com o passado. Tal relação ocorre no sentido de que o passado passa a ser reconsiderado em função do novo, e este, ainda, avaliado por cada leitor em função do antigo. Há, portanto, nesta análise, uma relação cíclica que envolve trocas mútuas entre o antigo e o novo, num movimento capaz de afetar a ambos.

Considero fundamental a reflexão sobre o conceito de "intertextualidade" como sendo incompatível com a ideia de "modelo" implícita, por sua vez, no conceito de influência. Assim, uma concepção relacionada à memória da literatura permite analisar a circularidade dos efeitos de sentido, de modo que não se trata mais de identificar um modelo para valorizá-lo. Segundo SAMOYAULT (2008):

Das inumeráveis re-escrituras, o autor não faz a síntese, mas retém elementos esparsos, ligados diversamente à trama dramática imutável. A restrição desta trama e sua fundamentação mítica garantem ao autor a liberdade dos outros motivos. (SAMOYAULT, 2008:115).

A noção de intertextualidade conforme desenvolvida por SAMOYAULT (2008) permite identificar como o texto de Yoko Tawada ressignifica os textos milenares com os quais trabalha a partir de uma construção ficcional própria. O sentido é comandado pelo seu texto em um constante trabalho de modificação e da própria relação-mosaico existente entre os textos. Nesse sentido, a intertextualidade, conforme expõe SAMOYAULT (2008), possui dois componentes essenciais: a transformação e a relação. Tais elementos implicam trazer à tona as obras antigas e colocá-las em um novo âmbito de sentido, onde são realimentadas pelo sentido de obras novas feitas sobre esta memória do antigo.

A memória, por sua vez, é uma noção central neste movimento, que abrange o texto, o autor e o leitor, em jogos de múltiplas interpretações (cf. SAMOYAULT, 2008:10). O percurso seguido por SAMOYAULT (2008) sobre a intertextualidade permite pensar esse conceito como memória, de modo que:

(...) os liames que se elaboram entre os textos não são atribuíveis a uma explicação ou a um inventário positivista: mas isto não impede que se fique sensível à complexidade das interações existentes entre os textos, do ponto de vista da produção tanto quanto da recepção. (SAMOYAULT, 2008: 143) 
A reflexão em relação ao movimento das obras mostra como os estudos intertextuais substituíram a sucessão pelo movimento. Desse modo, a fixidez dos encadeamentos histórico-lógicos deu lugar ao estudo da circularidade dos enunciados e, em decorrência disso, as questões de influência não importam mais de modo decisivo. O que se torna relevante é a "possibilidade que oferece a intertextualidade de mostrar como se constitui, em profundidade, em espessura e em tempo, um estilo ou uma linguagem." (SAMOYAULT, 2008:139).

A intertextualidade seria, assim, um princípio fundamental para a constituição do espaço literário. Ao dizer que o material da literatura é mais frequentemente linguagem já colocada como literatura existente, SAMOYAULT, (2008:145) afirma que "a citação, a re-escritura, a transformação e a alteração (...) só destacam o trabalho comum e contínuo dos textos, sua memória, seu movimento." Neste contexto, consideramos essa discussão sobre a noção de intertextualidade indispensável para o objeto específico da tradução, na medida em que aponta caminhos que permitem mostrar como a memória do "passado livresco" pode ter sido transformada, recriada, mantida em movimento em virtude de seu uso - ou de sua negação - no contemporâneo.

Dadas essas noções iniciais que baseiam nosso entendimento sobre intertextualidade no âmbito deste trabalho, tratamos mais especificamente sobre os dois intertextos citados anteriormente a partir das relações estabelecidas com a obra traduzida. Ressaltamos que o intuito não é buscar uma interpretação da obra de Yoko Tawada através de "pistas" a serem desvendadas nas Metamorfoses ou no Livro do Travesseiro, mas sim discutir sobre o diálogo realizado pela autora com essas obras milenares.

Assim, tal levantamento intertextual não pretende ser "explicativo" ou esclarecedor, no sentido de trazer ao leitor relações pré-estabelecidas entre Ópio para Ovídio e os dois textos clássicos, mas sim, fazer com que o leitor possa ser levado à autora através das referências literárias expostas por ela. Como um dos objetivos deste trabalho é apresentar ao leitor brasileiro Yoko Tawada, uma autora ainda não publicada em português, acreditamos ser importante trazer um aparato mínimo de informações sobre esta relação intertextual presente na obra estudada. 
Inicialmente, cabe apontar alguns aspectos do Livro do Travesseiro, uma obra japonesa redigida entre os anos de 994 e 1001 (Cf. WAKISAKA e CORDARO, 2013:7) escrita, portanto, cerca de mil anos depois das Metamorfoses de Ovídio e mil anos antes de Opium für Ovid. Os acontecimentos escritos na Corte de Teishi por Sei Shônagon tratam de figuras da corte e de seu cotidiano. É importante notar que, segundo WAKISAKA (2013: 9), o processo de leitura e escrita neste contexto da corte se dava entre as damas e eram coletivos. Segundo CUNHA (2013:83) havia dois gêneros nesta época: o monogatari, mais próximo à narrativa e representado pelo Romance do Genji e o gênero zuihitsu, exemplo tido como originário do Japão, que representa algo "feito ao correr do pincel", com crônicas da vida na corte, trechos introspectivos e poemas, como no Livro de Travesseiro.

Com relação à temática, segundo WAKISAKA (2013: 10) "o que se conclui é que, se a ala do Imperador se dedicava a registros históricos oficiais, próprios do universo dos homens, a de Teishi se dedicaria a relatos privados, mais próximos do mundo das mulheres". Neste contexto, também é interessante notar a rica produção literária japonesa feita por mulheres na época de Sei Shônagon (Cf. CuNHA, 2013:76). Ressaltamos aqui a questão do papel representado pela escrita na circulação de poder, tema relevante na obra de Yoko Tawada, conforme apresentado na seção 1.3. Segundo CUNHA (2013:83), a literatura era ferramenta para promover a imagem da mulher enquanto culta e fascinante, de modo que tinha papel central no processo de circulação do poder.

A importância das mulheres na produção literária na época de Sei Shônagon no Japão parece ser retomada por Yoko Tawada neste Livro do Travesseiro de vinte e duas mulheres. Em Ópio para Ovídio, há personagens linguistas, redatoras, estudantes de letras e escritoras. A personagem Coronis, cuja narrativa de mesmo nome é apresentada no próximo capítulo, é poeta e, ao chegar na cidade para a qual imigrou, pensou em procurar trabalho numa loja de departamentos:

Coronis estava somente há alguns meses na cidade, vagava de conhecidos em conhecidos, ainda não tinha um trabalho. Ela queria trabalhar no depósito de uma loja de departamentos. Quando Leda ouviu isso, ficou horrorizada e disse: "uma poeta não pode trabalhar em um depósito".

Coronis retrucou: "conheço muitos poetas que trabalham como lixeiros. " "E como eles ainda conseguem ser poetas?" 
"Justamente pelo fazer poético. Eles não têm necessidade de provar que são poetas pela recusa de um trabalho simples." (Coronis: pg. 104, linha 244) ${ }^{58}$

É possível identificar no trecho acima a importância do ato em si da escrita, o "poetar" como sinônimo de fazer, independente de um trabalho ou profissão com os quais os poetas se sustentam. A personagem enfatiza, ainda, a ação do fazer poético como algo erótico, de modo que ela satisfaz seu desejo carnal através da escrita:

Um vício doentio por pessoas força Coronis a se lançar sobre um indivíduo indefeso para feri-lo. O prazer sexual, por outro lado, tem para ela algo de autista. Ela não precisa de outra pessoa, mas de uma linguagem. Coronis experimenta o clímax carnal ao escrever. São sete horas da manhã. Um pardal pousa em um galho e a observa pela vidraça de uma janela. O pardal, a polícia secreta, vê como a mulher escreve com uma máquina de escrever antiquada e fica excitada com isso. (Coronis: pg. 106, linha 304)

Ainda no que se refere à questão da autoria, conforme o título da obra sugere pela palavra "von" 59 Ein Kopfkissenbuch von 22 Frauen (Um Livro do Travesseiro de 22 mulheres), as mulheres podem ser, além de personagens, também autoras deste livro. Em princípio, esse Livro do Travesseiro contemporâneo é delas e sobre elas. Na narrativa Clymene, por exemplo, é explicitado o processo de escrever ou de produzir palavras. Esta reflexão está ligada a Clymene, personagem linguista, e explicita a necessidade de se colocar a continuidade em questão em um estado de entorpecimento:

Em um estado-torpor abrem-se por todo lado pequenos furos entre os sons, entre o inspirar e o expirar, ao piscarmos. Eles colocam a continuidade em questão. Um "t" não garante que um "o" Ihe siga. Há uma ruptura entre ambos e nisso pode estar tudo terminado. Quais pontes ligam ambos os sons? Em um estado-torpor não posso mais falar como se tudo continuasse a transcorrer de modo óbvio. No meio de uma palavra tomo ar para ver se a frase continua ${ }^{60}$. (TAWADA, 2011:96)

58 Quando forem citados trechos de Latona ou Coronis, traduzidas no âmbito deste trabalho, a referência será dada como neste exemplo: (Coronis: pg. 104, linha 244) que se refere, respectivamente, ao nome da narrativa, ao número da página desta dissertação e à linha em que o trecho se encontra nas traduções em edição bilíngue no capítulo 3, seção 3.2.

59 Cf. GeISEL, 2011:50

60 „In einem Rauschzustand öffnen sich überall kleine Löcher, zwischen den Lauten, zwischen dem Ein - und Ausatmen, beim Blinzeln. Sie stellen die Kontinuität in Frage. Ein "r“ garantiert nicht, dass 
Conforme apresentado na seção 1.3, a estranheza do alemão como língua estrangeira se dá para Tawada já no âmbito do sistema de escrita alfabético. A autora faz considerações a respeito das letras enigmáticas do alfabeto, de modo que um $B$ pode virar tanto Bombe (bomba) como Blume (flor) e diz: “ (...) Escrever significa, em primeiro lugar, colocar letras e com isso colocar corpos alfabéticos no mundo sem pensar na sua ilimitada capacidade de "metamorfose". (TAWADA, 1998:30-32). ${ }^{61}$ A continuidade é colocada em questão no texto de Yoko Tawada, de modo que as possibilidades do vir a ser são inúmeras e enfatizadas pelo seu trabalho de escrita.

A descontinuidade também é perceptível nos acontecimentos escritos sobre a Corte de Teishi por Sei Shônagon, que seguem de maneira desconexa, assim como em Ópio para Ovídio, em que há recorrência de elementos concomitantes, como lembranças, imaginação, introspecção e discurso direto. Ainda no que se refere às características narrativas do livro de Tawada, a(s) narradora(s) em primeira pessoa apresenta $(\mathrm{m})$ diversas facetas e, em princípio, não é possível atribuir a ela(s) uma identidade definida. Em princípio, se poderia afirmar que a narradora nunca coincide com a personagem que dá título à história narrada, mas tal instância é fluída e, por vezes, é difícil saber de quem é essa "voz", que poderia se diluir entre todas as personagens.

Neste livro de Yoko Tawada, as esferas parecem ser propositalmente difusas ou não explícitas. Em um movimento de interpretação lógica, buscamos espontaneamente por pistas que nos ajudem a entender, no sentido de nossa tradição de buscar atribuir significados muito bem definidos a tudo. No entanto, em Ópio para Ovídio tudo parece estar ao bel prazer do mundo ficcional e uma forma de explicitar a construção desse mundo se dá neste trecho da narrativa luno (Juno):

ein „a“ ihm folgt. Es gibt eine Unterbrechung zwischen beiden und darin kann alles zu Ende sein. Welche Brücke verbindet beide Laute miteinander? In einem Rauschzustand kann ich nicht mehr so sprechen, als würde alles selbstverständlich weiterlaufen. Mitten in einem Wort hole ich Luft, um zu sehen, ob der Satz weitergeht."

NT. No texto de partida, a continuidade se dá entre "r" e "a", com possível referência à palavra Rauschzustand. Tentei recuperar esse jogo na tradução, alterando as letras para "t" e "o" , em referência a "torpor".

61 „Schreiben heißt zunächst, Buchstaben zu setzen und damit alphabetische Körper in die Welt zu setzen, ohne an ihre unbeschränkte Verwandlungsfähigkeit zu denken." 
"Juno fecha seus olhos e a autora Coronis desliga a máquina de escrever. Coronis sente agora seu próprio corpo tão pesado e quer, por isso, separar-se dessa personagem." 62 (TAWADA, 2011:200).

Além disso, é possível perceber essa dimensão da elaboração de um mundo fictício dentro da própria fiç̧ão em Latona, onde a narradora afirma que um trecho deve ser retirado do texto depois de o ter escrito. Assim, denota o fato de que este mundo é não só narrado, mas também criado por ela.

"Vocês têm pequenas chamas nas pontas dos pés", eu disse. Latona ergueu um pé e respondeu:

"Antigamente somente os homens podiam usar coisas vermelhas, porque vermelho era a cor do guerreiro e ..."

"Sim, exatamente", interrompeu Cila e continuou a falar revirando a língua. Latona silenciou. Cila sempre reagia rápida demais e precipitada demais, como se, caso contrário, algo fosse ser retirado dela. De repente, me ocorreu que Latona e Cila nunca haviam se conhecido. Esta cena aqui descrita precisa, então, ser riscada do texto. (Latona, pg.85, linha 45).

Um tipo inconstante de instância narrativa aparece também nas Metamorfoses de Ovídio, mas, neste caso, os narradores são explicitados, como por exemplo, a gralha, o corvo etc. O livro das Metamorfoses apresenta um caráter fragmentário, assim como o mundo ficcional de Ópio para Ovídio, de modo que é possível observar em ambos a ausência de uma linearidade narrativa ou temática. Nesta obra de Ovídio, são apresentados inúmeros mitos com deusas, deuses, semideuses, ninfas, humanos, animais, de modo que não há uma temática una. ${ }^{63}$

Neste contexto, apresento um outro aspecto de aproximação entre as duas obras, que diz respeito ao fato de que as personagens de Tawada fazem referência às deusas de Ovídio, como Níobe e a narradora de sua história em Ópio para Ovídio:

62 „Iuno schließt ihre Augen und die Autorin Coronis schaltet die Schreibmaschine aus. Coronis empfindet jetzt ihren eigenen Körper als so schwer und will sich deshalb von dieser Figur trennen."

63 As referências de Ovídio, no caso, voltam-se mais para Hesíodo, em contraponto a Homero e à temática una como, por exemplo, o retorno de Odisseu, na Odisseia. 
Níobe gosta de encontrar deusas que são mais altas do que ela. Uma provocação presenteia Níobe com novas forças (...). Eu estava sentada sobre um pedaço de nuvem, meus braços estavam entrelaçados na forma do número oito, eu deixava meu corpo balançar para um lado e para outro sem objetivo. Uma existência como metrônomo. ${ }^{64}$ (TAWADA, 2011: 133)

Além dos nomes mitológicos, há outras referências a acontecimentos descritos por Ovídio que explicitam o diálogo de Ópio para Ovídio com as Metamorfoses. Para citar um breve exemplo, transcrevo aqui uma fala de Níobe sobre Latona nas Metamorfoses, e, posteriormente, o encontro ríspido entre as duas na narrativa de Yoko Tawada. Nas Metamorfoses, Livro IV - Fábula $3^{\circ}$, chamada Níobe convertida em estátua, Latona é insultada por Níobe e esta recebe uma espécie de punição. É pertinente ressaltar, ainda, que neste livro de Ovídio, Latona é expulsa, errante, sendo essa ideia também parte de um campo semântico importante na obra de Tawada, juntamente com migrar, viajar e se deslocar, conforme exposto na seção 1.3. A seguir, transcrevo a fala de Níobe sobre Latona em Ovídio, conforme tradução de PREDEBON (2006: 295,296):

\footnotetext{
"Por que ousais preferir a mim Latona, que nasceu de um gigante e, a quem a Terra

Sendo tão vasta negou pouso humilde Quando a prole quis dar às vitais luzes A deusa que adorais foi uma expulsa do céu, do mar, da terra: vagabunda."
}

Quando se observa o encontro dessas duas personagens em Ópio para Ovídio há, a meu ver, um ponto importante a ser desenvolvido em relação ao mito e à ironia presente no texto de Yoko Tawada. Conforme GeISEL (2011: 48): "toda ironia é alheia ao mito: não há distância em relação ao acontecido" ${ }^{65}$. No texto de Tawada, esse distanciamento é desejado e a ironia é um instrumento que pode provocá-lo, conforme aponta o trecho abaixo:

64 „Niobe trifft gerne Göttingen, die höher gewachsen sind als sie. Eine Provokation schenkt Niobe neue Kräfte (...) Ich saß auf einem Stück Wolke, meine Arme waren in der Form der Zahl Acht verflochten, meinen Körper ließ ich zwecklos hin- und herschwanken. Eine Existenz als Metronom."

65 „Jede Ironie ist dem Mythos fremd: es gibt keine Distanz zu dem was sich ereignet”. 
Latona apontou com o dedo indicador a saia curta da oradora e cochichou que não precisamos economizar tecido na saia para trazer à luz a situação econômica da classe trabalhadora. A oratória da mulher desconhecia falta de matéria. Ela continuou a falar por mais uma hora. Quando finalmente parou de falar, veio até Latona e disse algo num tom provocador. Latona tentou se esquivar das pontas das flechas dessa mulher, que se chamava Níobe. Algumas mulheres se juntaram ao redor das duas. A simpatia da maioria se coloca ao lado de Latona. A voz de Níobe se tornou mais aguda e estridente, por fim, ela nos deixou sem se despedir. (Latona, pg.86, linha100)

Neste ponto, faz-se importante retomar nosso entendimento sobre o conceito de intertextualidade, principalmente no que se refere à subversão dos modelos. A ironia pode ser considerada um ponto de subversão da Antiguidade, sendo a subversão, por sua vez, uma das quatro posturas que SAMOYAULT (2008) propõe na relação com o modelo, juntamente com admiração, desenvoltura e denegação. Descrevo aqui brevemente os quatro pontos para que possamos situar melhor a subversão, postura que mais interessa no caso da obra de Yoko Tawada, na medida em que sua lida com o passado não se estabelece numa relação de assimilação do modelo, mas sim de sua perturbação.

Inicialmente, são expostos alguns aspectos da admiração, sobre a qual a autora afirma que "A relação com o modelo implica uma deferência para com as virtudes pedagógicas dos Antigos, não uma submissão absoluta." (SAMOYAULT, 2008:131). Assim, nem mesmo um trabalho advindo desse tipo de postura é subjugado pelo modelo. No caso da desenvoltura em relação aos modelos, a autora diz que é preciso colocar a intertextualidade a favor da singularidade dos textos "observando o modo como as vozes se fazem ouvir diferentemente, segundo seu lugar nos textos" (SAMOYAULT, 2008:132). A denegação, por sua vez, implicaria a deformação que o novo provoca no antigo. A autora diz que, às vezes, o novo faz desaparecer o antigo "(...) em proveito de uma apropriação definitiva, maneira radical de negá-lo" (SAMOYAULT, 2008:133).

Quanto à subversão, acredito ser pertinente a maneira como SAMOYAULT descreve a estética pós-moderna, em que o passado livresco não tem mais função fundadora ou fundamental para a criação futura, de modo que o uso da intertextualidade "obriga a pensar diferentemente não só a relação com o outro e com o modelo como também a constituição de si como modelo eventual." (SAMOYAULT, 2008:135). Assim, essa perspectiva rompe definitivamente com toda 
ideia de transmissão, trazendo à tona o fato de que a modernidade relativiza tal ideia de transmissibilidade, dando um outro estatuto à citação.

Tendo em vista essa perspectiva da relação com o passado literário, ressaltamos que este estudo sobre intertextualidade apresenta o livro como pluralidade pura e constituído por:

(...) material esparso, lascas, restos, fragmentos. É assim que o pós-modernismo trata o passado como desordem e explora a biblioteca como pluralidade. A palavra de ordem daquilo que se chama pós-modernidade reside, com efeito, na valorização da multiplicidade, em nome do relativismo dos fatos e dos fenômenos, da valorização dos textos heterogêneos, tanto visíveis quanto lisíveis, misturando materiais e elementos de natureza diferente, transformando os hábitos de leitura e os usos da narração. (SAMOYAULT, 2008:143)

Nesse sentido, retomemos o já citado caráter fragmentário de Ópio para Ovídio. Esse caráter está presente não só nas instâncias narrativas e no encadeamento aparentemente sem nexo das diferentes histórias de cada uma das vinte e duas personagens, mas também na própria sintaxe e em outras características do estilo da escrita de Yoko Tawada. Notam-se frases curtas e passagens que revelam uma história "em cacos", como no início da narrativa Latona:

Eu vejo uma coluna de labaredas erguer-se de uma colina. De novo uma nova usina atômica? Eu tinha visto com frequência cartazes parecidos. Por isso, não duvido em momento algum de que ele se volte contra à construção de uma nova usina atômica.

Latona se põe a meu lado e me conta como foi estimulante o último curso de fim de semana sobre Budismo Tibetano. De repente, vejo na mesma imagem uma completamente outra: a colina representa a cabeça raspada de um ser meditante. De sua cabeça ele cospe pensamentos de fogo. (Latona, pg.84, linha1)

Além da fragmentação, é possível identificar no trecho acima, assim como em tantos outros deste livro, processos de alteração de perspectivas ou transformações do estado físico de pessoas e coisas. O princípio da metamorfose em Latona, em Coronis e nas outras "mulheres-capítulos" permeia a observação das personagens, e se constitui, ainda, como a constante possibilidade do vir a ser. As percepções se transformam ou apresentam invariavelmente sempre mais do 
que uma possibilidade de interpretação. Quanto ao próprio "motivo" metamorfoses, Yoko Tawada observa:

A metamorfose é, na história da literatura europeia, um tema raro e, até onde estou informada, não há entre as Metamorfoses de Ovídio e de Kafka nenhum romance em que este seja o tema principal. Por outro lado, este é um tema importante na cultura do leste asiático, nas religiões asiáticas, no Budismo e também na mitologia, nos contos de fada e assim por diante. (TAWADA em entrevista a HORST, 2009: 83) 66

O tema "metamorfose" é bastante caro à autora e em seu livro de ensaios Verwandlungen (Metamorfoses), no capitulo Gesicht eines Fisches oder das Problem der Verwandlung (Rosto de um peixe ou o problema da metamorfose), a autora ressalta que o Livro das Metamorfoses de Ovídio nos faz atentar para o fato de que as definições são fictícias (TAWADA, 1998:55). Segundo Tawada (cf. 1998:66), a palavra da moda "perda de identidade" suplantou o conceito de metamorfose.

Contudo, a metamorfose é, desde a Antiguidade, - seja dos gregos ou dos chineses - um dos importantes motivos da literatura." ${ }^{7}$ Ainda no livro Verwandlungen, Tawada trata do primeiro capítulo das Metamorfoses de Ovídio, em que as formas dos seres existentes eram indefinidas e, portanto, a possibilidade do vir a ser e de se transformar é constitutiva da origem de tudo, conforme descreve na passagem transcrita abaixo:

Nas 'Metamorfoses' de Ovídio, é narrada no primeiro capítulo uma espécie de origem do mundo que é, ao mesmo tempo, uma explicação sobre a capacidade de cada ser de se metamorfosear. A ideia de que um ser pode sequer se metamorfosear em outro vem de um tempo em que as formas dos seres vivos e das coisas ainda não estavam definidas. (TAWADA, 1998:54) ${ }^{68}$

66 „Die Verwandlung ist in der Geschichte der europäischen Literatur ein seltenes Thema, soweit ich informiert bin, gibt es zwischen den Metamorphosen von Ovid und Kafka gar keinen Roman, in dem dies das Hauptthema ist. Dagegen ist das ein wichtiges Thema in der ostasiatischen Kultur, in den asiatischen Religionen, im Buddhismus und auch in der Mythologie, in Märchen und so weiter."

67 „das Modewort “Identitätsverlust” hat den Begriff der Verwandlung in die Ecke verdrängt. Die Verwandlung ist aber seit der Antike - sei es der griechischen oder der chinesischen - eines der wichtigen Motive der Literatur"

68 “In Ovids `Metamorphosen` wird im ersten Kapitel auf eine Weise von der Entstehung der Welt erzählt, die gleichzeitig eine Erklärung für die Verwandelbarkeit der Einzelnen Wesen ist. Die Vorstellung, dass ein Wesen sich überhaupt in ein anderes verwandeln kann, stammt aus der 
É possível identificar diversas formas de concretização das metamorfoses no âmbito de Ópio para Ovídio, como em Latona, em que sua metamorfose consiste também na transformação de seu próprio corpo:

Ela olha no espelho e vê um rosto estreito, lavado com neve, a camada de gordura se descolou da pele, linhas suaves estão ao redor dos olhos e na testa, a abertura da boca se tornou mais escura, os olhos mais úmidos, novos cabelos cresceram abundantes, eles brilham prateados. (Latona, pg.96, linha 424)

Outros processos de metamorfoses estão ligados à coisificação de pessoas e à humanização de coisas e de animais. A seguir, estão transcritos trechos dos dois textos traduzidos, Latona e Coronis, que ressaltam essas transformações. $\mathrm{Na}$ primeira passagem transcrita abaixo, os objetos passam a ter pelos e se transformam em objetos de carícia. Algumas linhas depois, ainda em Latona, os corpos flutuantes citados num curso de Budismo coexistem com as partes do corpo de um catálogo. Elas estão prontas para serem encomendadas em um processo que retrata a coisificação do humano e, mais especificamente, do corpo feminino.

Com a tecnologia genética tinha se tornado possível, por exemplo, fazer crescer pelos na superfície de uma escrivaninha, de uma cadeira ou de uma cama. Entre jovens profissionais de carreira surgiu então rapidamente uma nova cultura de móveis. Eles obtiveram finalmente algo para acariciar e abraçar, mas que era fácil de cuidar e não era viciado em amor. (...)

O instrutor do curso disse que há muitos corpos, eles flutuam no ar, mas nenhum deles nos pertence. Mas talvez nosso desejo seja possuir um corpo, ao menos vez ou outra, talvez apenas às segundas ou somente na primavera. Latona sempre volta a olhar saudosa para trás. Ela vê alguns corpos atrás de si, dos quais iria gostar. Ela já os tinha deixado e também queria esquecê-los. Mas agora acreditava que estes corpos tinham sido roubados dela e integrados a um catálogo. Um rosto estreito, cabelos lisos, finos, seios pequenos, um quadril estreito e dedos longos. Latona folheou o catálogo e pegou sem querer um telefone para encomendar algumas partes do corpo. Se no pedido for ultrapassado um determinado valor, não é necessário pagar pelos custos do envio. Assim, encomendar o máximo possível. Então Latona volta a se lembrar das palavras do instrutor do curso. Os corpos que podemos ver já se foram. É burrice querer segurá-los. Latona coloca o telefone novamente sobre a mesa de cabeceira e começa a cortar as unhas do pé. (Latona, pg.88, linha 153)

Erinnerung an die Zeit, in der die Gestalten der Lebewesen und der Dinge noch nicht bestimmt waren." 
Em Coronis, o processo de transformação se dá no âmbito da perspectiva do observador em relação às coisas. Os objetos cotidianos são encarados de modo distinto do usual, devido ao estado entorpecido da narradora. Eles podem adquirir características humanas como uma barriga ou o sentimento de tranquilidade:

\begin{abstract}
No estado-torpor descubro um gesto estranho dos objetos cotidianos, eles agem como se não fossem eles mesmos, como se fossem apenas recipientes para outra coisa. Minha carteira tem moedas em sua barriga, o corpo da minha velha caneta tinteiro está cheio de tinta, minha xícara azul de chá comporta tranquila o líquido escuro e também a janela é o lado da frente de um aquário. Eu vejo uma paisagem de água ali dentro. Lá fora chove. O que se encontra no recipiente chamado "carvalho"? (Coronis, pg. 97, linha 1)
\end{abstract}

Como dito anteriormente, além da humanização de objetos, é possível identificar nesse texto a atribuição de características humanas a animais, e, em especial, aos pássaros. Antes de apresentar exemplos de como isso ocorre em Ópio para Ovídio, recorro novamente ao livro Verwandlungen (Metamorfoses), de Tawada, que discorre no capítulo intitulado Stimme eines Vogels (voz de um pássaro), sobre a expressão "Bei dem piept es", que significa que alguém está maluco, enlouqueceu. O significado literal de piepen é "piar", ou seja, literalmente a frase significa "pia em alguém". Conforme descreve Tawada (1998:12): "há uma expressão interessante em alemão: „Bei dem piept es”. Uma voz, provavelmente de um pássaro, fala então, e a forma de pensar de uma pessoa, na qual "pia", é influenciada pela voz." 69

Em Coronis, o marido da protagonista desenha um pássaro que the conta segredos sobre sua mulher:

O cartunista acende um cigarro, pega um pedaço de papel na mão e desenha simplesmente um pássaro branco. Às vezes ele precisa entre uma coisa e outra desenhar pequenas figuras, como se faz uma anotação, mas ele mesmo não sabe o que quer anotar com aquilo. Ele acerta o pássaro com um pincel, as penas são manchadas de marrom. O pássaro gorjeia, tua mulher não precisa de um homem para estar apaixonada. Então ele esvoaça e tenta voar para fora do papel. O

69 „Es gibt eine interessante Redewendung im Deutschen: „Bei dem piept es”. Eine Stimme, wahrscheinlich die eines Vogels, spricht dann, und die Denkweise einer Person, bei der "es piept”, wird von der Stimme beeinflußt". 
cartunista poderia lhe desenhar uma gaiola, mas é melhor que ele saia voando. Senão, o pássaro linguarudo poderia contar ainda mais coisas irritantes sobre sua mulher. (Coronis, pg.108, linha 382)

As referências aos pássaros aparecem em Ópio para Ovídio também em relação à personagem Leda, que nas Metamorfoses de Ovídio é seduzida por Zeus transformado em cisne. No Livro do Travesseiro de Tawada, há uma narrativa intitulada Leda e nas duas narrativas traduzidas há referências a ela. Em Coronis, seu nome vem à tona em razão de sua morte, descrita como uma mulher semiparalisada. Em Latona (pg. 93, linha 324), não há menção ao nome de Leda, mas ao bater de asas enquanto uma mulher de braços paralisados se banha:

\begin{abstract}
Latona conheceu há vinte anos algumas mulheres no Ottensen que não tinham banheira em casa. Para o banho elas vinham à sua casa.

Uma dessas mulheres vinha regularmente no primeiro dia do mês à casa de Latona para banhar-se. Latona não conseguia se lembrar já naquela época de onde a conhecia. A mulher tinha uma barriga muito achatada, talvez tivesse intestinos curtos demais. Os braços pendiam sem força para baixo, como que paralisados. Somente as unhas agiam vigorosas, elas eram afiadas pontiagudas e pintadas de vermelho-sangue. A mulher não falava muito. Mas quando desaparecia no banheiro, Latona ouvia pouco depois um forte bater de asas.
\end{abstract}

Neste ponto, retomo a questão da atualização feita por Yoko Tawada dos mitos descritos nas Metamorfoses de Ovídio, de modo que ela os faz vivos e, ao mesmo tempo, os subverte. Segundo SAMOYAULT:

(...) o eterno retorno é um mito, mas é também o princípio constitutivo do mito, cujo enunciado é sempre reiterado e indefinidamente re-atualizado. Contando uma origem, ou esforçando-se por dar uma origem a uma cultura, a uma história, a uma nação, o mito dissolve, no entanto, sua própria origem na multiplicidade de suas versões. (SAMOYAULT, 2008:115).

A possibilidade de diálogo com os mitos é bem-vinda no espaço do texto de Yoko Tawada e pode se constituir como gesto transformador, metamorfose em si, na medida em que coloca perspectivas em questão. No cotidiano fragmentado das personagens, é constante a presença de modelos de significação alheios a determinada lógica individual ou compartilhada. Desse modo, a escrita de Tawada pode promover o questionamento em relação a delimitações de caráter identitário 
ou nacional e, ainda, inverter determinadas perspectivas ocidentais construtoras de um dado "Oriente". É interessante notar que Tawada percebe, como exposto na passagem abaixo, a estética das Metamorfoses de Ovídio como sendo mais próxima ao ideário asiático do que propriamente do ocidental. Segundo GEISEL:

\begin{abstract}
As vinte e duas mulheres modernas com nomes antigos (...) encontram-se na cabeça entorpecida de ópio de uma narradora em primeira pessoa que não se surpreende com nada (muito ao contrário do público leitor, principalmente o europeu). A estética das "Metamorfoses» de Ovídio estaria mais próxima à visão de mundo asiática do que da tradição ocidental, considera Yoko Tawada. Em japonês, como se sabe, não há um pronome específico para «eu» e também o conceito de «identidade» surge possivelmente do jargão da psiquiatria. A concepção budista do renascimento não conhece um eu fechado em si, mas sim uma interminável sequência de transformações, inclusive para além dos limites de gênero literário. Na Europa marcadamente cristã, ao contrário, cada pessoa é um ser único, cuja existência tem um começo e, nos ensinamentos sagrados, um objetivo. Com "Opium für Ovid» Yoko Tawada quebra a expectativa do leitor europeu, pois todas as regras de causalidade e coerência são abolidas. «Eu só poderia ter escrito esse livro em alemão. Em japonês esse experimento não teria tido sentido» ${ }^{70}$ (GEISEL, 2001)
\end{abstract}

Como dito anteriormente, um dos elementos através dos quais Yoko Tawada concretiza essa experimentação é a ironia. A autora ironiza a necessidade europeia de buscar uma identidade formadora de cada indivíduo, imutável e, muitas vezes, indissociável de seu caráter nacional. Também são ironizadas a visão eurocêntrica de mundo ou uma ótica ocidental construtora de um determinado "Oriente". Em Latona, os cursos de Budismo de fim de semana coexistem com a percepção da origem do Budismo Tibetano como consequência da reunificação alemã. Na

70 „Die zweiundzwanzig modernen Frauen mit antiken Namen (...) befinden sich im opiumberauschten Kopf einer Ich-Erzählerin, die sich (sehr im Gegensatz zu der Leserschaft, vor allem der europäischen) über nichts wundert. Die Ästhetik von Ovids «Metamorphosen» sei der asiatischen Weltsicht näher als der abendländischen Tradition, meint Yoko Tawada. Im Japanischen gibt es bekanntlich kein selbständiges Pronomen für «ich», auch der Begriff «Identität» taucht allenfalls im psychiatrischen Fachjargon auf. Die buddhistische Vorstellung der Wiedergeburt kennt kein in sich geschlossenes Ich, sondern eine endlose Abfolge von Verwandlungen, auch über Gattungsgrenzen hinweg. Im christlich geprägten Europa dagegen ist jeder Mensch ein einmaliges Wesen, dessen Existenz einen Anfang und, in der Heilslehre, ein Ziel hat. Mit «Opium für Ovid» durchbricht Yoko Tawada die Erwartung der europäischen Leser, denn alle Regeln von Kausalität und Zusammenhang sind aufgehoben. «Ich konnte dieses Buch nur auf Deutsch schreiben. Im Japanischen hätte ein solches Experiment keinen Sinn gehabt.»"

Trecho consta em entrevista à Sieglinde Geisel (2001) publicada no site do jornal suíço Neue Zürcher Zeitung In: http://www.nzz.ch/article71HPS-1.468004 
passagem transcrita a seguir, é possível observar a tensão de ordem nacional entre a China e o Tibete. Os rostos nus dos tibetanos aparecem em contraposição às máscaras usadas na Ópera de Pequim, uma manifestação teatral originalmente chinesa que envolve acrobacia, música, dança, mímica e artes marciais:

No jornal leio que o Budismo Tibetano seria uma consequência da reunificação alemã. Quando de repente a fronteira do Ocidente se deslocou muito além para o Oriente, a China se revelou um vizinho suspeito. Aqueles que até aqui haviam se identificado em suas atividades políticas com as vítimas da Segunda Guerra Mundial se enfiavam agora na figura dos tibetanos. Eles diziam: na Ópera de Pequim sempre foi usada uma máscara, na qual pintávamos nossas esperanças, mas preferimos os rostos nus dos tibetanos, nós os salvaremos. (Latona, pg.91, linha 238)

A máscara é um tema recorrente na obra de Yoko Tawada. Na narrativa Das Fremde aus der Dose (O Fremde da lata), citada na seção 1.3, aparece a questão do fremd relacionada a uma máscara que se constitui numa expressão do rosto atrás do qual buscamos algo de conhecido. Retomemos aqui a metáfora da máscara colocada na fisionomia alheia, na medida em que parece ser preciso atribuir um caráter minimamente reconhecível ao estranho. Isto, já que entendemos o Outro a partir de nossos modelos de significação, pelos quais concebemos o mundo.

Yoko Tawada mostra em sua obra diferentes significações atribuídas a um mesmo objeto, personagem ou acontecimento. Seja pelo torpor, pelas transformações e metamorfoses, pela criação autoral, pelas perspectivas da realidade de seu mundo ficcional, pela tensão entre o nacional e o estrangeiro, a escritora aponta para as camadas que constituem um sujeito híbrido, constituído também pelas expectativas alheias:

As expectativas dos observadores produzem máscaras e elas crescem para dentro da carne dos estrangeiros. Assim, os olhares dos outros são continuamente inscritos no próprio rosto. Um rosto pode adquirir muitas camadas. Talvez seja possível folhear um rosto como uma narrativa de viagem. (TAWADA, 1998:53) ${ }^{71}$

71 „Die Erwartungen der Betrachter erzeugen Masken, und die wachsen ins Fleisch der Fremden hinein. So werden stets die Blicke der anderen ins eigene Gesicht eingeschrieben. Ein Gesicht 
O contato com o estrangeiro se dá em grande medida pelo deslocamento das pessoas, de modo que as viagens têm papel fundamental nesse encontro com o Outro e na respectiva atribuição de significados ao desconhecido para tentar decifrá-lo. Temas como a migração e os deslocamentos em geral são tratados por Tawada de maneira a provocar uma inversão de perspectivas e, em seu texto, o "nativo" é o alemão, como será apresentado nas notas à tradução, no capítulo 4. A personagem Coronis emigrou e, ao chegar no país para o qual se mudou, vagava pela cidade, morando com conhecidos e em busca de trabalho. No trecho abaixo, é possível identificar a estranheza por parte das pessoas e também o incômodo gerado nela ao ser perguntada pela origem:

Coronis é frequentemente observada por passantes. Os olhos dos moradores do vilarejo fitavam-na. Os olhos dos da cidade grande fitavam-na da mesma forma: nos bondes, nos restaurantes, nas lojas de departamento. Isso é tão mais enigmático, pois nela não há nada que chame atenção, algo que se possa sentir como alheio ao lugar.

"De onde a senhora vem? ", perguntam todos os jovens vendedores de legumes, quando veem Coronis. Os ancestrais desses homens provêm de um outro país. Coronis tenta sorrir. É algo natural quando pessoas jovens fazem tais perguntas. Mas naturalidades podem deixar Coronis nervosa.

"De onde a senhora vem? ", os homens repetem sua pergunta, como se tivessem um direito de saber disso. Não se pode naturalmente fazer essa pergunta para qualquer cliente, para um homem nativo, por exemplo, não se pode simplesmente perguntar onde ele nasceu. Mas para uma mulher que ainda não se definiu, se pode perguntar tudo.

Coronis tenta como outras mulheres ressignificar este assédio em um reconhecimento de seu poder de atração. Para algumas pessoas a pergunta sobre a origem é a única pergunta erótica que ainda podem fazer em público.

Um dia Coronis conta à diretora do centro cultural durante uma xícara de café sobre este problema que a atormenta no cotidiano.

"Eu gostaria de poder comprar tomates sem ser questionada pela origem. "

A diretora sentiu-se atingida.

"Por que não se pode lhe fazer perguntas? Eu acho isso uma curiosidade saudável."

Coronis silencia. Em uma democracia é um tabu proibir perguntas a alguém.

(Coronis, pg.110, linha 447)

kann mehrere Schichten erhalten. Vielleicht kann man ein Gesicht wie einen Reisebericht umblättern.“ 
Como dito anteriormente, o trecho acima expressa o desconforto da personagem em relação à insistente pergunta sobre sua origem, assim como a crítica em relação à "naturalidade" que assumem essas perguntas a certas mulheres. Tal questionamento ressalta a diferenciação estabelecida entre os que pertencem a um determinado país e os de fora dele, os estrangeiros.

É explícita no texto a contraposição entre o eu, com seu caráter nacional definido e o Outro, o que é alheio a essa experiência coletiva de pertencimento nacional. A personagem está na categoria de "estranha" a este pertencimento em contraponto à diretora que, talvez por jamais ter sido perguntada pela origem, acha saudável tal curiosidade. Ao final do texto Coronis, é descrito um sonho em que a questão nacional vem novamente à tona:

\footnotetext{
Um sonho no qual algumas aves canoras são definidas como prato nacional. Não é claro quem pertence a qual nação e é tido como constrangedor perguntar sobre isso. Um punho estorricado com um pouco de algo verde em meu prato. A refeição é pedida aqui já antes do nascimento do convidado. O prato canta seu hino nacional, talheres frios estalam perto dele. Um comentário salta da mesa dos habitués:
}

"Pessoas pobres comem tudo o que encontram. Mas nós não comemos nada que cante e voe."

Do lado ensolarado da janela alguém afirma:

"Carne de ave é saudável."

Do lado crítico do porão a opinião insurge:

"Nós queimamos a bandeira da nação bárbara, pois eles ainda devoram, como no século passado, carne. Em caso de emergência, deveríamos estrangulá-los economicamente." (Coronis, pg. 112, linha 520)

A ideia de nação é ironizada e exposta em uma refeição não compartilhada, fragmentada em diferentes delimitações como as de caráter nacional. Os limites impostos para formar uma personalidade imutável não condizem com a perspectiva de transformação contínua das protagonistas de Ópio para Ovídio. Nenhuma delas apresenta uma identidade óbvia, por assim dizer, mas passam constantemente por transformações, assim como expõem um constante deslocamento do olhar. No decorrer da narrativa, diferentes perspectivas são expostas e invertidas, como na seguinte passagem de Latona (pg.96, linha 405): 
De vez em quando, Latona recebe cartas de uma então companheira de república. "Não é maravilhoso que a Guerra do Ópio finalmente chegue ao fim?", escreveu essa amiga que havia se mudado para Pequim. "Muitos acreditam que ela já tivesse acabado há séculos, mas na minha opinião isso não é correto. Somente agora essa guerra chega ao fim. Agora o Tibete é o torpor, o país industrial China não precisa mais fazer o papel do fumador de ópio. Latona balança a cabeça. Como essa mulher consegue morar sozinha do outro lado da Terra? Lá estão todos de pontacabeça e chove da Terra."

Nesse texto, os modelos de significação com os quais se interpreta o mundo são sempre passíveis de mudança. A dissolução da (auto)encenação se relaciona dentre outros elementos, a um estado de torpor gerado pelo ópio, em que os significados dão lugar à atribuição de significações mutáveis (Cf. GEISEL, 2011: 53). O título Ópio para Ovídio indica um texto onde a questão da autoria também é tratada de modo difuso e com caráter fragmentário. O ópio parece ser um indício de que as representações com caráter fixo podem ser deturpadas. A droga age, assim, como uma espécie de água asiática no corpo da Literatura Ocidental, metamorfoseada em algo que não comporta os clichês do orientalismo ou a construção identitária isenta de transformações. Essas transformações são representadas materialmente, como na própria escrita de Coronis:

"Eu admiro sua literatura há dez anos. Suas frases têm algo de entorpecedor (...) Eu tinha me referido com "entorpecedor" na verdade a uma substância-torpor concreta que nas frases de Coronis pode ser materialmente sentida."

Coronis (pg.109, linha 424)

As transformações são, assim, concretizadas fisicamente na própria matéria dos seres e discursivamente através da língua. Nesse sentido, é pertinente ressaltar a dimensão material de uma linguagem e, portanto, do discurso. Cada letra pode ser materialmente sentida, assim como a dimensão física da transformação da autora pela água tomada no decorrer de sua viagem pela Transiberiana, conforme descrito na seção 1.1.

A metamorfose ressalta a dimensão material do ser e acaba por (de)formar sua personalidade, mais propensa ao vir a ser, ao transmudar-se. No Livro do Travesseiro de Tawada, o deslocamento de perspectivas é uma constante em que um Ovídio entorpecido traz à tona o intertexto como memória e, ao mesmo tempo, 
constituído no presente, a cada vez que se realiza.

Yoko Tawada desvela algo que se aproxima ou pode ser aproximado nas tradições e, assim, reinventa sua própria tradição. A autora transforma o antigo em algo novo e ambos permanecem em movimento em função das relações com o passado e com a contemporaneidade, se reinventando na construção dessa memória literária, a cada (re)leitura e, inclusive, na tradução. Dessa forma, a tradução pode ser lida como parte do processo de atualização do diálogo criado por Tawada com os dois textos milenares.

Retomo a visão de Yoko Tawada sobre tradução exposta na seção 1.3, onde apresentamos a noção de deslocamento que, segundo a escritora, está implicada também na tradução. $O$ estranhamento que perpassa sua obra não poderia, assim, ser destruído ou apagado em prol de uma homogeneização linguístico-cultural. A estética das Metamorfoses expressa pelo formato do Livro do Travesseiro promove a quebra de expectativas e ressalta o caráter estrangeiro que um tipo de sociedade homogeneizante parece negar.

Nesse sentido, busco desempenhar no presente trabalho o papel de uma tradutora comprometida com a visão de Yoko Tawada sobre tradução e com os parâmetros considerados por ela para o processo tradutório, que se relacionam ao deslocamento do olhar e à tentativa de fazer com que o leitor se depare com uma língua "outra", constituída entre a sua própria e a língua estrangeira. Sendo assim, apresentamos no próximo capítulo a tradução em si, precedida de uma nota, em que expomos a estratégia e o método utilizados. Ambos orientam este trabalho de tradução comentada, cujo correlato da inteligibilidade seria não perder o intertexto de vista, visando sua reelaboração e a experimentação com o estrangeiro. 


\section{Capítulo III}

\section{Tradução e nota prévia}

A tradução de Latona e de Coronis apresentada neste capítulo busca não somente ilustrar os temas discutidos ao longo da dissertação, mas constitui, ela mesma, a demonstração do exercício tradutório perseguido no decorrer deste trabalho. As narrativas traduzidas são precedidas por uma nota (seção 3.1) onde estão expostos a estratégia adotada para o processo tradutório e o método utilizado no decorrer do mesmo.

A não interferência e a não explicação se constituem como princípios deste trabalho, concretizados pela escolha de elementos capazes de remeter o leitor ao texto de partida e à sua autora. Tais elementos são apresentados logo após as traduções, no capítulo (4) desta dissertação, onde são comentados a partir da possibilidade ou dificuldade de serem recuperados no texto de chegada.

Assim, considerando a visão de Yoko Tawada sobre o caráter transformador da tradução, conforme expusemos na seção 1.3, constam, a seguir, alguns aspectos teóricos que fundamentam minha atitude como tradutora e como pesquisadora, segundo a estratégia de permitir que o caráter estranho e estrangeiro do texto de partida transpareça no texto traduzido. 


\title{
3.1. NOTA PRÉVIA: ESTRATÉGIA E MÉTODO
}

Esta nota prévia à tradução visa a apresentar os aspectos teóricos que embasam a estratégia de desenvolver um exercício de não-esclarecimento dos elementos possivelmente estranhos à cultura e à língua de chegada. Inicialmente, antes de tratarmos sobre a estratégia propriamente dita, faz-se importante destacar a Skopostheorie (Cf. SNELL-HORNBY, 1998:105-107), teoria segundo a qual a decisão por determinada estratégia de translação depende do Skopos, ou seja, do objetivo da mesma. Segundo VERMEER:

\begin{abstract}
Vemo-nos perante um dilema, aliás desde há muito discutido na teoria da tradução (vide Schleiermacher) ou se distancia o texto do leitor de chegada, para o qual a tradução se destina, através de sua versão dita literal ou se lhe aproxima o texto adaptando-o aos hábitos da cultura de chegada. E não é possível obter os dois resultados ao mesmo tempo: manutenção da forma e aproximação do efeito. (...) E como a escolha de uma das estratégias expostas é obrigatória - há que escolher quer se queira ou não - é outra vez aquela nossa regra suprema que nos faz e permite decidir-nos: é o objectivo da tradução que determina qual dos dois caminhos se pode e deve seguir. (VERMEER: 1985:7-8)
\end{abstract}

Sendo assim, retomemos o objetivo geral deste trabalho: apresentar ao leitor a autora Yoko Tawada e uma de suas obras, ilustrada na tradução de duas narrativas, Latona e Coronis. Tal apresentação deve ser feita de maneira coerente com a visão da própria escritora sobre o caráter estrangeiro presente em si mesma e em sua obra, além das características que, segundo ela, deve possuir uma tradução. O texto traduzido deve conter, segundo TAWADA (1998:35), um caráter de deformação, de deslocamento e deve, ainda, provocar no leitor o sentimento da existência de uma língua completamente diferente, conforme exposto na seção 1.3.

Yoko Tawada acredita na possibilidade de expor essa existência de uma "língua outra" através do caráter da tradução. Nesse ponto, cabe retomar o objetivo específico deste trabalho, apresentado na sua introdução, que consiste no exercício em si de traduzir, de modo que a dissertação deve servir como estudo preliminar sobre a autora e sua obra. Esse exercício se dá no âmbito de um trabalho acadêmico, para um público leitor provavelmente vinculado à área acadêmica, cujo 
contexto propicia, em princípio, algumas tentativas de transposição não comumente aceitas pelo mercado editorial.

Diante desses objetivos, voltemos à dualidade presente na citação acima de VERMEER que retoma SCHLEIERMACHER ao expor os dois principais caminhos que pode seguir uma tradução: um mais literal, que se distancia do leitor de chegada, ou aquele que se aproxima dele, estando mais de acordo com os hábitos da cultura de chegada. Segundo SCHLEIERMACHER (2001 [1813]), o leitor deve ser levado ao autor e não o contrário, já que isto significaria apagar o caráter estrangeiro do texto. E, no caso de Ópio para Ovídio, esse caráter estrangeiro é duplo, pois está presente em certa medida também na relação que o texto estabelece com a cultura de partida.

Conforme SCHLEIERMACHER, mais do que uma leitura facilitadora, em que o tradutor visa a escrever um texto em sua língua, como se o autor do texto de partida o tivesse escrito na língua de chegada, buscamos desenvolver neste trabalho um exercício de manutenção do caráter estrangeiro do texto alemão, de modo a conduzir o leitor por um caminho rumo à autora e à língua na qual escreve.

No âmbito dessa discussão, é importante notar que TouRY (1995:57), por sua vez, considera como "norma inicial" a escolha feita pelos tradutores que se concretizará num continuum entre dois polos. Segundo sua perspectiva, os tradutores podem se sujeitar às normas realizadas no texto fonte ou às normas da cultura ou da língua alvo. Se o texto traduzido for em direção ao texto fonte, será, segundo o autor, "adequado". Se, por outro lado, as normas da cultura alvo prevalecerem, o texto traduzido será "aceitável". Ressalto que esses polos de adequação e de aceitabilidade se constituem num continuum, uma direção seguida por determinada tradução, que dificilmente será totalmente adequada ou totalmente aceitável.

BRITTO (2010:138) também propõe essa espécie de contínuo de tal forma que a atitude do tradutor não deve ser necessariamente extremada, mas afirma que "é preciso forçar o leitor a sair da tranquilidade de seu mundo conhecido e obrigálo a enfrentar o outro em toda sua estranheza". O autor cita BERMAN (2007) ao destacar a importância de "receber o Outro enquanto Outro" (in: BRITTO, 2010:139). Segundo BERMAN (2002 [1984]:18), uma má tradução seria aquela que “(...) sob 
pretexto de transmissibilidade, opera uma negação sistemática da estranheza da obra estrangeira e ainda:

(...) toda cultura resiste à tradução mesmo que necessite essencialmente dela. A própria visada da tradução - abrir no nível da escrita uma certa relação com o Outro, fecundar o Próprio pela mediação do Estrangeiro - choca-se de frente com a estrutura etnocêntrica de qualquer cultura, ou essa espécie de narcisismo que faz com que a sociedade deseje ser um todo puro e não misturado. Na tradução, há alguma coisa da violência da mestiçagem. (BERMAN, 2002 :18)

Esse processo de "mestiçagem", conforme nomeia BERMAN, pode ser verificado ao recuperarmos o diálogo dos movimentos literários alemães com textos antigos e suas traduções, que enriqueceram a língua de chegada com temas e formas. BERMAN, ao falar de Goethe e Hölderlin, por exemplo, destaca que a tradução pode despertar possibilidades latentes na língua (cf. BERMAN, 2002 [1984]:18). E, talvez possamos acrescentar, as possibilidades latentes nos gêneros literários e na cultura. $\mathrm{Na}$ visão de Herder e de outros autores alemães do Classicismo e do Romantismo, a tradução apresenta-se como fonte de novas formas e possibilidades para a língua de chegada através do contato com o estrangeiro.

Ópio para Ovídio dialoga com textos antigos, clássicos em suas respectivas culturas e, de algum modo, retoma um movimento já tradicional na literatura alemã, onde não parece haver espaço para a negação do estrangeiro. Como apresentado nos dois primeiros capítulos deste trabalho, a atitude de Yoko Tawada como escritora, estrangeira em meio a outros tantos autores e autoras com origens linguístico-culturais diversas, pode promover o contato com o Outro, o alheio a certa concepção de normalidade ou de naturalidade. Nesse sentido, o caráter homogêneo de uma cultura ou da identidade de um indivíduo é constantemente negado em sua obra.

O diálogo intertextual em Ópio para Ovídio, por sua vez, explicita a condição do Outro, do que é distinto e pode invocar uma certa estética de estranhamento. $O$ texto aponta para uma pluralidade de perspectivas e pode propiciar uma experiência de alteridade tanto em sua língua de partida, como numa tradução, de modo que a cultura de chegada compõe mais uma camada às culturas envolvidas 
no percurso dessa obra.

Sendo assim, minha atitude como tradutora busca estabelecer um trabalho dentro do contínuo entre a língua estrangeira e a língua de destino para que a linguagem da tradução contenha em si esse caráter heterogêneo e, até certo ponto, ambivalente. Como diz BERMAN:

No plano psíquico, o tradutor é ambivalente. Ele quer forçar dos dois lados: forçar a sua língua a se lastrear de estranheza, forçar a outra língua a se de-portar em sua língua materna. Ele quer ser escritor, mas não é senão re-escritor. Ele é autor - nunca o Autor. (BERMAN, 2002 :18-20)

Ainda com relação à essa dualidade, ressaltamos aqui, conforme LARANJEIRA (2003), os fatores socioculturais e linguístico-estruturais implicados na tradução:

“(...) cujo exame ponderado deve determinar no sujeito-tradutor a escolha de uma reescritura mais próxima do módulo original ou mais condizente com os usos poéticos da língua-cultura receptora." (LARANJEIRA, 2003:138 e 139).

Embora na sua Poética da Tradução (LARANJEIRA, 2003), o autor se concentre especificamente na tradução de poemas, destacamos brevemente alguns pontos desse trabalho, na medida em que suas reflexões podem auxiliar na tomada das decisões tradutórias também nos textos em prosa.

Inicialmente, cabe ressaltar que não faz parte do escopo desta dissertação tratar do complexo e, por vezes, problemático conceito de fidelidade e suas vertentes teóricas. Vamos nos ater a uma pequena parcela da proposta desenvolvida por LARANJEIRA, de modo mais amplo, sem nos concentrarmos detalhadamente em cada um dos tipos de fidelidade consideradas por ele: retóricoformal, semântica, linguístico-estrutural e semiótico-textual.

LARANJEIRA (2003) propõe um conceito dinâmico de fidelidade que, segundo ele, não significa eliminar as tensões existentes entre o texto original e o texto traduzido. Essa visão de tradução se coaduna com a de Yoko Tawada e contempla, ao invés de tentar anular, as tensões existentes na complexidade da relação com o Outro, na dinâmica entre autor e tradutor, língua-cultura de partida e língua-cultura de chegada. LARANJEIRA propõe trabalhar com essas questões de modo a obter um 
texto homogêneo, mas não subalterno. Esse trabalho por parte do tradutor se faz, segundo ele:

a partir da leitura de um texto que não é seu, leitura que é uma expedição às profundezas do texto alheio para roubar-lhe a centelha viva do fogo sagrado: a significância. (LARANJEIRA, 2003:124).

Nesse contexto, há uma leitura própria de cada tradutor, de modo que a presença do sujeito no processo tradutório não se constitui pela mera translação de estruturas semântico-sintáticas. LARANJEIRA afirma, referindo-se a MESCHONNIC (1973:413), que a fidelidade deve marcar-se mais pela presença do sujeito a gerar a tradução-texto como “(...) relação entre duas línguas-culturas: não o desaparecimento fictício da alteridade, mas a relação em que se está aqui e hoje, situado, com referência ao traduzido." (In: LARANJEIRA 2003:125).

No que se refere à fidelidade semântica, isto é, aquela voltada ao "sentido" de um texto, pode-se dizer que ela talvez exerça a maior influência quando se trata da tradução compreendida como transporte de sentido de uma língua de partida a uma de chegada. Contudo, LARANJEIRA esclarece a importância de não se confundir uma alteração consciente e motivada na tradução semântica com erros propriamente ditos. Essa alteração consciente deve existir em função da "significância", que abrange a manifestação do poético como um todo e não se reduz ao nível estritamente semântico.

Quanto à fidelidade linguístico-estrutural, LARANJEIRA ressalta o cuidado que o tradutor deve ter no sentido de:

(...) preservar ou recuperar, no seu trabalho de reescritura, os jogos de significantes da cadeia original (nos níveis sintático e prosódico das classes morfológicas, léxico, fônico), na medida em que constituam bases em que se apoia a significância. (LARANJEIRA, 2003: 127).

Considerando a ideia de significância do texto original, é preciso realizar o exercício de mantê-la no texto-tradução (cf. LARANJEIRA, 2003) e, para tanto, faz-se necessário pensar em um jogo de compensações capaz de resgatar o que há de literário na narrativa. Dessa forma, a identificação dos pontos a serem resgatados. 
deve ser feita a partir de uma leitura detida com foco no caráter literário da obra.

Como os exemplos e comentários sobre a tradução expostos no capítulo 4 buscam explicitar, o exercício de traduzir no presente trabalho se deu na direção de uma aproximação com as estruturas da língua de partida e de uma tentativa de recuperar certas marcas do texto Ópio para Ovídio, como o caráter narrativo fragmentário e os procedimentos utilizados para a construção de ironia, que de alguma forma devem fazer parte do texto traduzido.

Sendo assim, observamos que o ato de traduzir não implica uma simples transposição de sentido ou tampouco uma reprodução servil de estruturas da língua estrangeira, mas sim a construção de uma tradução autônoma, que se dá através do trabalho com a cadeia de significantes que ambos os textos devem conter.

No contínuo entre os dois polos ambivalentes que constituem as escolhas tradutórias - a manutenção da forma e a aproximação do efeito - há várias facetas que a tradução pode assumir: adequada ou aceitável; domesticada ou estranha; estrangeirizadora ou facilitadora. Neste trabalho, o exercício consistiu em direcionar as escolhas tradutórias o quanto possível em direção ao estrangeiro, o que causa, por vezes, um efeito de estranhamento no texto de chegada.

Entendemos, contudo, que esse caráter estrangeiro da obra se coaduna com o que foi apresentado nos dois primeiros capítulos desta dissertação, em que o fremd permeia desde o subsistema literário em que estão inseridos os autores que escrevem em alemão como língua estrangeira (Fremdsprache) até as narrativas traduzidas no âmbito deste trabalho.

Embora as questões tradutórias que envolvem especificamente Latona e Coronis sejam apresentadas nos comentários posteriores à tradução, no capítulo 4, cabe adiantar desde já que há passagens do texto em que determinadas construções ressaltam características da língua alemã talvez já "naturalizadas" para um falante nativo. As "naturalidades", porém, parecem ser a todo momento desconstruídas, de modo que o texto transparece um caráter fremd, no sentido de promover a alteração das perspectivas mais comumente compartilhadas.

Conforme apresentado na seção 1.3 e retomado nestas notas, a visão de TAWADA (1998:35 e 36) sobre o texto traduzido é de que ele toca na superfície do texto de origem sem se fazer dependente de seu núcleo. Os parâmetros 
relacionados à concepção de uma tradução, segundo a autora, estão vinculados às noções de literalidade, deformação e transposição para a língua alvo. O texto de chegada teria, assim, um caráter de deslocamento que não deve ser apagado, mas sim considerado como um resultado revigorante.

Nesse sentido, o ato de traduzir Yoko Tawada implicou o respeito pela diferença, de modo que o texto de chegada não poderia ser reduzido ao já conhecido pela cultura de chegada. Assim, fazendo jus ao pensamento da escritora sobre tradução, o exercício tradutório se deu em direção ao caráter fremd do texto, não como assimilação acrítica do estrangeiro a despeito da língua portuguesa, mas como tentativa de fazer coexistir o próprio e o alheio numa língua particular ao texto traduzido.

Quanto ao método utilizado para tal exercício, destacamos que, no início deste projeto, o caminho traçado foi da prática tradutória para a teoria e, posteriormente, prática e pesquisa teórica foram concomitantes. É importante ressaltar que tanto o ato de traduzir como o texto resultante desse processo servem de objetos de análise. Sendo assim, as questões tradutórias consideradas mais relevantes serão apresentadas e discutidas no capítulo 4, posterior à tradução. Nesse mesmo capítulo também será ilustrada a estratégia adotada no decorrer dessa pesquisa, desenvolvida, como dito inicialmente, no sentido de evitar uma atitude explicativa.

Isso significa, dentre outras atitudes, eliminar todas as notas de rodapé do texto traduzido e não buscar alternativas facilitadoras em português, que acabariam por encobrir questões mais desafiadoras no processo de traduzir. Esse processo pode ser identificado nas versões intermediárias da tradução, disponibilizadas para consulta $^{72}$ por serem capazes de explicitar o caminho percorrido pelo texto traduzido. Como é possível perceber nas versões iniciais, houve um momento de maior aclimatação do texto à cultura e à língua de chegada. Posteriormente, a tradução foi se deslocando em direção ao estrangeiro de modo mais radical e, por fim, passou por algumas moderações, no sentido de eliminar alguns pontos, cujo

\footnotetext{
${ }^{72}$ As versões intermediárias da tradução podem ser acessadas pelo link: https://www.dropbox.com/home/Alice\%20do\%20Vale
} 
estranhamento foi considerado excessivo ou desnecessário.

A tradução dos textos Latona e Coronis, apresentada na próxima seção em versão bilíngue, se constitui no exercício tradutório em si e representa a forma como escolhemos colocar em prática a estratégia e o entendimento da tradução como exercício da diferença e não como compromisso com a igualdade ou com a equivalência. 
3.2. TRADUÇÃo 


\section{Latona}

Ich sehe eine Flammensäule aus einem Hügel ragen. Schon wieder ein neues Atomkraftwerk? Ich hatte oft ähnliche Plakate gesehen. Deshalb zweifle ich keinen Moment, dass es gegen den 5 Bau eines neuen Atomkraftwerkes gerichtet ist. Latona stellt sich neben mich und erzählt mir, wie anregend der letzte Wochenendkurs über Tibetanischen Buddhismus gewesen sei. Plötzlich sehe ich in demselben Bild ein ganz 10 anderes: Der Hügel stellt den rasierten Kopf eines meditierenden Menschen dar. Aus seinem Kopf spuckt er Feuergedanken.

Von der Vagina bis zum Scheitel wächst ein Rohr, es wächst jede Sekunde neu durch den 15 Körper hindurch. Ich meine nicht den anatomischen Körper, in den die Mediziner handkolorierte Eingeweide hineingestopft haben. Ich meine auch nicht den Körper, den man in einem Spiegel sehen kann. Ebenso 20 wenig meine ich den Körper, den die Krankenkasse uns jeden Monat verkauft. Ein neuer Körper, schon wieder ein neuer. Wie viele Körper muss man mit sich schleppen? Einige der Körper sind unangemeldet. Sie sind zwar 25 erotisch, aber für keinen sexuellen Akt nutzbar. Vielleicht sind sie illegal, aber sie können nicht bestraft werden, denn sie sind unsichtbar. In dem Rohr, das durch einen der Körper wächst, bläst ein kräftiger Wind von unten nach

30 oben. Der Luftzug kann den Schädel jedoch nicht erreichen, weil ein Stöpsel auf der Höhe der Lungen sitzt und die Kraft der Luft niederdrückt. Der Wind im Rohr bläst immer gleich stark, seine Kraft reicht nicht aus, um den Stöpsel

\section{Latona}

Eu vejo uma coluna de labaredas erguer-se de uma colina. De novo uma nova usina atômica? Eu tinha visto com frequência cartazes parecidos. Por isso, não duvido em momento algum de que ele se volte contra à construção de uma nova usina atômica.

Latona se põe a meu lado e me conta como foi estimulante o último curso de fim de semana sobre Budismo Tibetano. De repente, vejo na mesma imagem uma completamente outra: a colina representa a cabeça raspada de um ser meditante. De sua cabeça ele cospe pensamentos de fogo.

Da vagina até o topo da cabeça cresce um duto, ele cresce novo a cada segundo pelo corpo adentro. Não me refiro ao corpo anatômico, que os medicinos entupiram de entranhas coloridas à mão. Também não me refiro ao corpo que se pode ver em um espelho. Tampouco me refiro ao corpo que o sistema de saúde nos vende todo mês. Um novo corpo, outra vez um novo. Quantos corpos a gente tem de carregar consigo? Alguns dos corpos não se anunciam. Eles são, sim, eróticos, mas inúteis para qualquer ato sexual. Talvez sejam ilegais, mas não podem ser punidos, pois são invisíveis.

No duto que cresce através de um dos corpos, sopra um vento forte de baixo para cima. A corrente de ar não consegue, no entanto, alcançar o topo da cabeça, pois um tampão está na altura dos pulmões e pressiona para baixo a força do ar. O vento no duto sopra sempre igualmente forte, sua força não basta 
35 wegzublasen. Man muss den Druck des Windes sammeln und inn auf einmal nach oben pressen. Dann bewegt sich der Stöpsel, beginnt zu brennen und fliegt durch den Scheitel in die Luft hinauf.

40 Das Wetter schwankte zwischen haltlos kühler Luft und feuchter Sonne. Während wir gemeinsam das Blumenbeet, in dem nur krumme Brechbohne wuchsen, bewunderten, bemerkt ich, das Latona und Scylla die gleichen 45 roten Schuhe trugen.

"Ihr habt kleine Flammen an den Fußspitzen“, sagte ich. Latona hob einen Fuß hoch und antwortete:

„Früher durften nur Männer rote Sachen 50 tragen, weil Rot die Farbe des Kämpfers war, und..."

„Ja genau“, unterbrach Scylla und redete mit wirbelnder Zunge weiter. Latona schwieg. Scylla reagierte immer zu schnell und $55 \mathrm{zu}$ hastig, als würde ihr sonst etwas weggenommen werden. Auf einmal fiel mir ein, dass sich Latona und Scylla nie kennengelernt hatten. Die hier beschriebene Szene muss also aus dem Text gestrichen werden.

60 Ich lernte Latona auf einer Wiese in der Nähe von Glückstadt kennen. Als ich dort ankam, lagen schon viele Fahrräder neben der Landstraße. Es war ein Sonntag, windstill und mild. Einige Menschen hatten ein Arafat-Tuch 65 um den Hals gebunden und holten ab und zu zerknitterte Taschentücher aus der Hosentasche, um sich die Nase zu putzen. Auf dem Tisch standen bereits Käse und Marmelade, darüber flogen Wespen herum. Es 70 wurde weder über den Beruf noch über den para soprar o tampão para fora. É necessário acumular a pressão do vento e de uma vez pressioná-lo para cima. Então o tampão se movimenta, começa a arder e voa através da cabeça pelo ar acima.

O tempo oscila entre inconstante ar fresco e sol úmido. Enquanto admirávamos o canteiro de flores no qual só cresciam vagens retorcidas, percebo que Latona e Cila usavam os mesmos sapatos vermelhos.

"Vocês têm pequenas chamas nas pontas dos pés", eu disse. Latona ergueu um pé e respondeu:

"Antigamente somente os homens podiam usar coisas vermelhas, porque vermelho era a cor do guerreiro e ..."

"Sim, exatamente", interrompeu Cila e continuou a falar revirando a língua. Latona silenciou. Cila sempre reagia rápida demais e precipitada demais, como se, caso contrário, algo fosse ser retirado dela. De repente, me ocorreu que Latona e Cila nunca haviam se conhecido. Esta cena aqui descrita precisa, então, ser riscada do texto.

Eu conheci Latona em um gramado nas proximidades de Glückstadt. Quando lá cheguei, muitas bicicletas já estavam no chão, perto da estrada vicinal. Era um domingo, ameno e quieto de vento. Algumas pessoas tinham um Lenço-Arafat amarrado em volta do pescoço e, vez ou outra, pegavam do bolso da calça lenços amassados para limpar o nariz. Sobre a mesa já havia queijo e geleia, por cima dos quais voavam vespas em volta. Não se falava nem sobre trabalho nem sobre 
letzten Urlaub geredet. Es gab anscheinend ein wichtigeres Thema, das die Menschen miteinander verband. Dieses Thema wurde aber nicht direkt ausgesprochen, so dass es mir 75 unklar blieb. Es musste ein politisches Thema sein, das mit Fahrrädern, Taschentücher, Wespen, Glückstadt, Schwarzbrot und Maikäfer zu tun hat. Die Menschen jubelten jedes Mal, wenn sie einen Maikäfer entdecken. ${ }_{80}$ Irgendwann sprach Latona mich an. Ihr Ton hatte etwas Unaufdringliches.

Nach einer Weile wurde es leicht windig und aschenfarbene Wolken rutschten von Norden herunter. Wie verabredet hörten alle 85 Anwesenden auf zu plaudern. Eine Frau, die auffällig modisch angezogen war, begann ohne ein einleitendes Wort Details zu erklären. Die bemerkenswerteste Eigenschaft jener Reihe von Kernen sei, dass sie sich spontan und ohne 90 äußere Einwirkungen wie Hitze oder Druck in andere Kerne umwandelten. Die Frage sei aber, ob es in der Natur überhaupt eine authentische Spontaneität gäbe, ob dies nicht ein Deckmantel sei, unter dem sich eine 95 politische Absicht verberge. Die Frau hörte nicht mehr auf zu reden. Die meisten Sätze wehten an mir vorbei, aber einen verstand ich doch: Wenn die Energie freigesetzt wird, werden Licht und Hitze erzeugt, an denen man stirbt.

100 Latona zeigte mir mit dem Zeigefinger den kurzen Rock der Sprecherin und flüsterte mir zu, man müsse nicht den Stoff am Rock sparen, um die wirtschaftliche Lage der Arbeiterklasse ins Licht zu bringen. Die 105 Sprechkunst der Frau kannte keinen férias.

Havia aparentemente um assunto mais importante que ligava as pessoas umas às outras. Esse assunto não foi diretamente expresso, de modo que para mim permaneceu impreciso. Devia ser um assunto político que tem a ver com bicicletas, lenços, vespas, Glückstadt, pão preto e escaravelhos. As pessoas jubilavam sempre que encontravam um escaravelho. Em algum momento Latona puxou conversa comigo. Seu tom tinha algo de sutil.

Depois de um tempo, começou a ventar levemente e nuvens cor de cinzas escorregaram do norte para baixo. Como que combinado, todos os presentes pararam de conversar. Uma mulher vestida visivelmente na moda começou a esclarecer detalhes, sem uma palavra introdutória. A mais notória característica daquela fileira de núcleos seria que eles se transformam em outros núcleos espontaneamente e sem influências externas como calor ou pressão. A pergunta seria, no entanto, se existe mesmo na natureza uma espontaneidade autêntica ou se isso não seria um disfarce sob o qual se encobre uma intenção política. A mulher não parava mais de falar. A maioria das frases passava soprando ao meu largo, mas uma eu entendi sim: quando a energia é liberada, são produzidos luz e calor dos quais se morre.

Latona apontou com o dedo indicador a saia curta da oradora e cochichou que não precisamos economizar tecido na saia para trazer à luz a situação econômica da classe trabalhadora. A oratória da mulher desconhecia falta de matéria. Ela continuou a falar por mais 
Stoffmangel. Sie redete noch eine Stunde weiter. Als sie endlich aufhörte zu reden, kam sie auf Latona $z u$ und sagte etwas in einem provozierenden Ton. Latona versuchte, den

110 Pfeilspitzen dieser Frau, die Niobe hieß, zu entweichen. Einige Frauen versammelten sich um die beiden. Die Sympathie der Mehrheit stellt sich auf Latonas Seite. Niobes Stimme wurde höher und kratzender, schließlich verließ 115 sie uns, ohne sich zu verabschieden.

„Jemand reißt mir die Haare aus, während ich schlafe. Aus Eifersucht. Ich weiß, dass jemand auf mich eifersüchtig ist".

Latona war nie richtig eifersüchtig, sie 120 hatte aber Sehnsucht nach einer erhitzenden Eifersucht, es war eine Sucht. Wie sehr sehnte sie sich nach einer Eifersucht! Im Wochenendseminar über den tibetanischen Buddhismus lernte sie eine Frau namens luno 125kennen, diese Frau beherrschte die Kunst der Eifersucht.

In diesem Herbst verlor Latona viele Haare. Während sie schlief, verließen sie einfach ihren Kopf, ohne Schmerzen, als hätten 130 sie nie Wurzeln in der Kopfhaut gehabt. Morgens lag ihr Kopfkissen unter einem Netz aus verlorenen Haaren.

Die Haarsteuer, die lange umstritten gewesen war, wurde schließlich doch eingeführt. Man 135 sagte, der Verein der Hamsterliebhaber hätte diese Reform veranlasst. Die Hamsterliebhaber uma hora. Quando ela finalmente parou de falar, veio até Latona e disse algo num tom provocador. Latona tentou se esquivar das pontas das flechas dessa mulher, que se chamava Níobe. Algumas mulheres se juntaram ao redor das duas. A simpatia da maioria se coloca ao lado de Latona. A voz de Níobe se tornou mais aguda e estridente, por fim, ela nos deixou sem se despedir.

"Alguém arranca meus cabelos enquanto durmo. Por ciúme. Eu sei que alguém tem ciúme de mim."

Latona nunca foi realmente ciumenta, ela tinha anseios por um ciúme ardoroso, era um vício. Como ela ansiava por um ciúme! No seminário de fim de semana sobre Budismo Tibetano ela conheceu uma mulher de nome Juno, essa mulher dominava a arte do ciúme.

Neste outono, Latona perdeu muitos cabelos. Enquanto dormia, os cabelos simplesmente deixavam sua cabeça, sem dores, como se nunca tivessem tido raízes no couro cabeludo. Pela manhã, seu travesseiro estava sob uma teia de cabelos perdidos.

O imposto sobre pelos, que tinha sido longamente discutido, foi por fim introduzido. Falava-se que a associação dos amantes de hamsters teria provocado essa reforma. É que os amantes de hamsters sempre acharam 
fanden es nämlich schon immer ungerecht, dass man für einen Hamster genauso viel Säugetiersteuer zahlen musste wie für einen 140 Schäferhund. Deshalb schlugen sie vor, die Höhe der Säugetiersteuer nach der Größe der Körperoberfläche der Tiere zu bestimmen. Das Finanzamt akzeptierte den Vorschlag, musste aber den Begriff der Körperoberfläche vermeiden, da es sonst wegen der 145 Diskriminierung fetter Menschen Ärger gegeben hätte. Einem, der von der Größe der Körperoberfläche spricht, fehlt es an politischer Sensibilität. So entstand die Idee, den Begriff der „behaarten Oberfläche einzuführen. Mit

${ }^{150}$ diesem Ausdruck wurde deutlich, dass nicht Menschen, sondern andere Säugetiere gemeint waren. Dabei vergaß man aber zu berücksichtigen, dass inzwischen auch Gegenstände behaart sein konnten. Durch die 155 Gentechnologie war es zum Beispiel möglich geworden, auf der Oberfläche eines Schreibtisches, eines Stuhles oder eines Bettes Haare wachsen zu lassen. Unter jungen Karrieremenschen entstand daher rasch eine 160 neue Möbelkultur. Sie bekamen endlich etwas zum Streicheln und zum Umarmen, das aber pflegeleicht und nicht liebessüchtig war. Auf jeden Fall war die Steuerreform nachteilig für Liebhaber der behaarten Möbel, denn nach der 165neuen Steuerregelung musste man jede behaarte Fläche versteuern. Sie waren aber nicht einzigen, die wesentlich mehr Steuer zahlen mussten als vorher. Eines Tages behauptete eine Gruppe von Beamten, dass 170man dem Gesetz nach seine Beine versteuern muss, falls sie behaart sind. Einige pensionierte injusto que se devesse pagar por um hamster exatamente o mesmo imposto sobre mamíferos como um pastor alemão. Por isso sugeriram que o montante dos impostos sobre mamíferos seja determinado pelo tamanho da superfície corporal dos animais. A Secretaria de Finanças aceitou a sugestão, precisava, entretanto, evitar o conceito de superfície corporal dos animais, já que poderia haver aborrecimento por conta da discriminação de pessoas gordas. Falta sensibilidade política a alguém que fala sobre o tamanho da superfície corporal. Assim, surgiu a ideia de introduzir o termo "superfície pilosa". Ficou claro com esta expressão que se referiam não às pessoas, mas sim a outros mamíferos. No entanto, esqueceram de considerar que nesse meio tempo objetos também podiam ter pelos. Com a tecnologia genética tinha se tornado possível, por exemplo, fazer crescer pelos na superfície de uma escrivaninha, de uma cadeira ou de uma cama. Entre os jovens profissionais de carreira surgiu então rapidamente uma nova cultura de móveis. Eles obtiveram finalmente algo para acariciar e abraçar, mas que era fácil de cuidar e não era viciado em amor. De todo modo, a reforma no imposto era desvantajosa para os amantes de móveis pilosos já que, segundo a nova regra do imposto, era necessário taxar toda superfície pilosa. Mas eles não eram os únicos que precisavam pagar consideravelmente mais impostos do que antes. Certo dia, um grupo de funcionários afirmou que, segundo a lei, é necessário taxar as pernas, caso sejam peludas. Alguns funcionários públicos pensionistas realizavam 
Beamte führten sogar ehrenamtlich Kontrollen an Badeorten durch. Studentinnen die wenig Geld besaßen, rasierten ihre Arme und Beine, 175um keine Steuer für behaarte Oberflächen bezahlen zu müssen. Die Haare auf dem Kopf ließen sie jedoch weiter wachsen, denn der Kopf war Steuerfrei. Auch die meisten männlichen Studierenden rasierten ihren 180 Körper. Männer wurden zwar selten kontrolliert, aber sie wollten kein Risiko eingehen. Das Studium war schon riskant genug, in allen anderen Lebensbereichen wollten sie deshalb lieber Sicherheit. Nur reiche Geschäftsleute, 185 Politiker und ihre Ehefrauen lagen unrasiert wie Bären an den Stränden. Der behaarte Körper wurde zum Statussymbol. Die Armut war dagegen nackt, glatt und weich. Unter Managern herrscht die Mode, auch aus ${ }_{190}$ Armbanduhren, Taschenrechnern und

Scheckkarten Haare von der gleichen Farbe wie ihre Körperhaare wachsen zu lassen. Die teuren Hormonspritzen, die man dafür brauchte, konnte man von der Steuer 195 absetzen.

Manchmal blättert Latona in einem Möbelkatalog. Er ist anscheinend für Menschen gedacht, die zwanzig oder dreißig Jahre jünger sind als sie und einen leeren Raum vor Augen 200 haben, den sie mit frisch riechendem Holzleben einrichten können. Latona betrachtet jedes Foto aufmerksam, als könnte sie dort auch für sich einen leeren Raum finden. Eines der abgebildeten Zimmer ist ganz hell. In der Luft até mesmo inspeções honoríficas em locais de banho. Universitárias que possuíam pouco dinheiro raspavam braços e pernas para não precisar pagar nenhum imposto sobre superfícies pilosas. No entanto, deixavam que os cabelos sobre a cabeça continuassem a crescer, pois a cabeça era isenta de impostos. A maioria dos estudantes masculinos também raspavam seus corpos. Homens eram raramente inspecionados, mas eles não queriam correr nenhum risco. $O$ estudo já era arriscado o suficiente, por isso optavam pela segurança em todas as outras esferas da vida. Somente pessoas de negócios, ricas, políticos e suas esposas ficavam nas praias sem se raspar como ursos. O corpo cabeludo tornou-se símbolo de status. A pobreza era, ao contrário, nua, lisa e macia. Entre os gerentes, domina a moda de deixar crescer pelos da mesma cor dos pelos do corpo também nos relógios de pulso, nas calculadoras de bolso e nos cartões do banco. As caras injeções de hormônios necessárias para isso podiam ser abatidas dos impostos.

Às vezes Latona folheava um catálogo de móveis. Ele parece ser pensado para pessoas vinte ou trinta anos mais jovens do que ela e que têm diante dos olhos um cômodo vazio que podem mobiliar com vida de madeira cheirando a fresco. Latona observa cada foto atentamente como se pudesse encontrar ali um cômodo vazio também para si. Um dos cômodos retratados é bem claro. No ar flutuam 
205 schweben Zahlen - zwei, neun, neun - , ein Komma und ein Strich. Wie sinnlich wirken die runden Rücken der Zahlen, die so einen günstigen Preis bezeichnen. Im Hintergrund ist auch eine Frau abgebildet, die zwischen einer 210 Kommode und einem Schuhkasten hockt. Nur an der Stelle, an der sich ihr Gesicht befindet, ist das Foto unscharf.

Der Seminarleiter sagte, es gebe viele Körper, sie schwebten in der Luft, aber keiner von innen 215 gehöre uns. Vielleicht möchte man aber doch einen Körper besitzen, wenigstens ab und zu, vielleicht nur montags oder nur im Frühling. Latona blickt immer wieder sehnsüchtig zurück. Sie sieht einige Körper hinter sich liegen, die ihr 220 gut gefallen würden. Sie hat sie schon verlassen und wollte sie auch vergessen. Aber nun glaubte sie, diese Körper seien ihr gestohlen und in einen Katalog aufgenommen worden. Ein schmales Gesicht, glatte, feine 225 Haare, kleiner Busen, ein schmale Hüfte und lange Finger. Latona blättert im Katalog und greift unwillkürlich nach dem Telefon, um einige Körperteile $z u$ bestellen. Wenn man bei der Bestellung eine bestimmte Rechnungssumme 230 überschreitet, muss man keine Versandkosten bezahlen. Also möglichst viel bestellen. Dann erinnert Latona sich wieder an die Worte der Seminarleiters: Die Körper, die man sehen könne, seien schon vergangen. Es sei dumm, 235 sie festhalten $\mathrm{zu}$ wollen. Latona stellt das

Telefon wieder auf den Nachttisch und beginnt, sich die Fußnägel zu schneiden. números - dois, nove, nove -, uma vírgula e um traço. Como parecem sensuais as costas redondas dos números que simbolizam um preço tão bom. Em segundo plano, também está retratada uma mulher agachada entre uma cômoda e uma sapateira. Somente no lugar em que se encontra seu rosto a foto está desfocada.

O instrutor do curso disse que há muitos corpos, eles flutuam no ar, mas nenhum deles nos pertence. Mas talvez nosso desejo seja possuir um corpo, ao menos vez ou outra, talvez apenas às segundas ou somente na primavera. Latona sempre volta a olhar saudosa para trás. Ela vê alguns corpos atrás de si, dos quais iria gostar. Ela já os tinha deixado e também queria esquecê-los. Mas agora acreditava que estes corpos tinham sido roubados dela e integrados a um catálogo. Um rosto estreito, cabelos lisos, finos, seios pequenos, um quadril estreito e dedos longos. Latona folheia o catálogo e pega sem querer um telefone para encomendar algumas partes do corpo. Se no pedido for ultrapassado um determinado valor, não é necessário pagar pelos custos do envio. Assim, encomendar o máximo possível. Então Latona volta a se lembrar das palavras do instrutor do curso. Os corpos que podemos ver já se foram. É burrice querer segurá-los. Latona coloca o telefone novamente sobre a mesa de cabeceira e começa a cortar as unhas do pé. 
In der Zeitung lese ich, dass der Tibetanische Buddhismus eine Folge der deutschen 240 Wiedervereinigung sei. Als sich die Grenzen des Westens plötzlich viel weiter nach Osten verschob, entpuppte sich China als ein verdächtiger Nachbar. Diejenigen, die sich in ihren politischen Aktivitäten bisher immer mit 245 den Opfern des zweiten Weltkrieges identifiziert hatten, schlüpften jetzt in die Gestalt der Tibetaner. Sie sagten: In der Peking-Oper wurde immer eine Maske getragen, auf die wir unsere Hoffnungen malten, die nackten 250 Gesichter der Tibetaner sind uns doch lieber, wir werden sie retten.

Latona entdeckt in der Zeitung ein Foto und schneidet es aus. Es zeigt einen roten Stoff, der in einem Ofen brennt. Der Stoff kann ein 255 Mönchsgewand sein oder eine Fahne. Neben der geöffneten Tür des Ofens sieht man das Markenzeichen des neuen chinesischen Autos „Der letzte Kaiser“. Latona erinnert sich daran, dass zwei große Strömungen im Buddhismus 260 gibt, die als der große Wagen und der kleine Wagen bezeichnet werden.

Latona spürt Schmerzen, wenn sie den Kopf bewegt. Ihr Nacken ist seit zwei Tagen verspannt.

265 „Was glauben Sie, warum ihr Nacken schmerzt", fragt der Seminarleiter.

„Weil ich wahrscheinlich zu viel arbeite und zu wenig an mich denke?", antwortet Latona.

„Nein. Weil ein Baum in einer Steppe in 270 Indien einseitig belastet ist. Schließen Sie Ihre Augen. Sie sehen doch einen dürren Baum,
No jornal leio que o Budismo Tibetano seria uma consequência da reunificação alemã. Quando de repente a fronteira do Ocidente se deslocou muito além para o Oriente, a China se revelou um vizinho suspeito. Aqueles que até aqui haviam se identificado em suas atividades políticas com as vítimas da Segunda Guerra Mundial se enfiavam agora na figura dos tibetanos. Eles diziam: na Ópera de Pequim sempre foi usada uma máscara, na qual pintávamos nossas esperanças, mas preferimos os rostos nus dos tibetanos, nós os salvaremos.

Latona encontra uma foto no jornal e a recorta. Ela mostra um tecido vermelho que arde em um forno. O tecido pode ser o hábito de um monge ou uma bandeira. Junto à porta aberta do forno, é possível ver o logotipo do novo carro chinês "O último Imperador". Latona se lembra que há duas correntes no Budismo chamadas de o grande veículo e o pequeno veículo.

Latona sente dores quando movimenta a cabeça. Seu pescoço está há dois dias tensionado.

"A senhora acha que seu pescoço dói por quê?", pergunta o instrutor do curso.

"Provavelmente porque eu trabalho demais e penso pouco demais em mim?", responde Latona.

"Não. Porque uma árvore em uma estepe na Índia está sobrecarregada em um dos lados. 
oder? Auf einem Ast sitzen sieben fette Raubvögel und auf der gegenüberliegenden Seite sitzt kein einziger Vogel.“

275 „Wieso ein Baum in Indien? Haben meine Schmerzen nichts mit mir zu tun?"

„Nein, Sie brauchen gar nicht an sich zu denken. Es genügt, dass andere Menschen an Sie denken. Stellen Sie sich diesen Baum, 280 diesen Schlafbaum, vor, und versuchen Sie, die Raubvögel von der einen Seite auf die andere Seite zu bewegen."

Der Seminarleiter grinst. Latona bemerkt, dass die Raubvögel in ihrem Kopf den Bildern in einem Computerspiel ähneln.

„Na? Wie ist Ihre Kopfhaut jetzt? Schlaff oder 285 straff?", fragt der Guru. Plötzlich wird Latona wütend über die Ästhetik, die den Meditationsraum beherrscht. Rundliche Buddhafiguren mit gekringelten Schnurrbärten, ein weißer Elefant und fette Wasserrosen. Der 290 Seminarleiter behauptet, alle Bilder im Raum basierten auf traditioneller asiatischer Kunst. Aber Latona glaubt inm nicht mehr. Er hat sie bestimmt einem Computerspiel entnommen. Latona möchte viel lieber ein dunkles, 295 ernsthaftes Bild, in dem man kaum eine Figur erkennen kann. Die Tiefe muss noch dunkel sein und nicht hell und bunt, denkt Latona. Die Meditation beginnt.

Der erste Versuch ging schief. Der zweite auch. 300 Schon seit Jahren gelingt es dem Guru nicht einmal, durch seelische Konzentration eine Zigarette anzuzünden. Wie kann er das Herz seiner Kunden anzuzünden, wenn er nicht
Feche seus olhos. Vê uma árvore seca, certo? Sobre um ramo estão sete gordas aves de rapina e, no ramo do lado oposto, não há nem uma única ave."

"Como assim uma árvore na Índia? Minhas dores não têm nada a ver comigo?"

"Não, não precisa de modo algum pensar em si. Basta que outras pessoas pensem em você. Imagine essa árvore, essa árvore do sono, e tente movimentar as aves de rapina de um lado para o outro."

O instrutor do curso dá um sorrisinho. Latona percebe que as aves de rapina se assemelham em sua cabeça às imagens de um jogo de computador.

"E então? Como está seu couro cabeludo agora? Frouxo ou teso?", pergunta o guru. De repente Latona fica furiosa com a estética que domina a sala de meditação. Figuras arredondadas de Buda com bigodes encaracolados, um elefante branco e gordas flores de lótus. O instrutor do curso afirma que todas as imagens da sala são baseadas na arte tradicional asiática. Mas Latona não acredita mais nele. Ele as tirou com certeza de um jogo de computador. Latona preferia muito mais uma imagem escura, séria, na qual quase não fosse possível reconhecer uma figura. A profundeza tem que ser escura e não iluminada e colorida, pensa Latona. A meditação começa.

A primeira tentativa deu errado. A segunda também. Já há anos o guru não consegue sequer acender um cigarro com a concentração mental. Como ele pode acender o coração de seus clientes, se não consegue sequer acender 
einmal eine Zigarette anzuzünden kann? Der 305 verzweifelte Heilige geht zu einem Physiker und lässt inn eine Göttin namens Shakti und einen Gott namens Agni herstellen. Auf dem Rücken des brennenden Körpers von Agni sitzt Shakti und startet. Die Presseleute sind schon darüber 310 informiert. Shakti versagt nicht. Shaktis Explosion kann in Zeitungen abgebildet werden.

Sie meinen, es gibt keinen Körper?“

„Körper gibt es viele in dieser Welt. Sie 315 schweben, fliegen, schwanken, springen und zittern. Sie gehören aber keinem Menschen.“

Latona kennt andere Dinge, die gleichzeitig vielen Menschen gehören: zum Beispiel ein Regenschirm oder ein Auto oder 320 ein gutes Buch oder eine Luftpumpe oder ein Bohrer. Ein Mensch, der zufällig einen dieser Gegenstände besitzt, muss inn anderen Menschen zur Verfügung stellen. Auch Badewannen gehören zu diesem Gegenstände. 325 Latona kannte vor zwanzig Jahren einige Frauen in Ottensen, die zu Hause keine Badewanne hatten. Zum Baden kamen sie zu inr.

Eine dieser Frauen kam regelmäßig am ersten 330 Tag des Monats zu Latona um zu baden. Latona konnte sich schon damals nicht mehr erinnern, woher sie sie kannte. Die Frau hatte einen sehr flachen Bauch, vielleicht hatte sie zu kurze Därme. Die Arme hingen kraftlos herab, 335 wie gelähmt. Nur die Fingernägel wirkten kräftig, sie waren scharf gewetzt und blutrot gemalt. Die Frau redete nicht viel. Aber wenn sie im Badezimmer verschwand, hörte Latona kurz darauf heftiges Flügelschlagen. Sie um cigarro? O santo desesperado vai a um físico e este produz uma deusa chamada Shakti e um deus chamado Agni. Nas costas do corpo ardente de Agni está Shakti e decola. O pessoal da imprensa já está informado sobre isso. Shakti não falha. A explosão de Shakti pode ser retratada nos jornais.

\section{"Você acha que não existem corpos?"}

"Corpos existem muitos nesse mundo. Eles pairam, voam, flutuam, saltam e estremecem. Mas não pertencem a nenhuma pessoa."

Latona conhece outras coisas que pertencem ao mesmo tempo a muitas pessoas: por exemplo, um guarda-chuva ou um carro ou um bom livro ou uma bomba de ar ou uma broca. Uma pessoa que, por acaso, possua um desses objetos precisa colocá-lo à disposição de outras pessoas. Também as banheiras pertencem a esses objetos. Latona conheceu há vinte anos algumas mulheres no Ottensen que não tinham banheira em casa. Para o banho elas vinham à sua casa.

Uma dessas mulheres vinha regularmente no primeiro dia do mês à casa de Latona para banhar-se. Latona não conseguia se lembrar já naquela época de onde a conhecia. A mulher tinha uma barriga muito achatada, talvez tivesse intestinos curtos demais. Os braços pendiam sem força para baixo, como que paralisados. Somente as unhas agiam vigorosas, elas eram afiadas pontiagudas $e$ pintadas de vermelho-sangue. A mulher não falava muito. Mas quando desaparecia no 
340 befürchtete jedes Mal, dass der Boden unter Wasser stand, aber das passiert nie. Der Boden, der Spiegel, die Wanne waren trocken, wenn die Frau das Bad verließ. Sie glänzen sogar, als hätte sie sie geputzt.

${ }^{345}$ Latona hat keine Berufsausbildung beendet. Sie tastet sich einfühlsam an jedem Ausbildungsweg entlang und verlässt inn, bevor die Hochzeitsglocken läuten. Sie will nicht gescheitert sein, denn das Wort Scheitern klingt $\mathrm{zu}$ heroisch. Keine Prüfung war für Latona 350 schwierig. Ihre Finger sind geschickt, sie hat ein feines Gehör und ein gut dehnbares Gedächtnis Sie spaziert durch zehn verschiedene Gärten der Ausbildungen, pflückt in jedem brauchbare Blumen und fühlt sich 355 hinterher nicht müde. Sie weiß nur nicht, welche Art Rentnerin sie werden sollte.Die Lebensphase als Rentnerin ist, ausgenommen der nach dem Tod und der vor der Geburt, die längste, so dass man sie ernst nehmen muss. 360 Diese Frage beschäftigt sie. Als Latona ein Mädchen war, wurde sie oft von einer Tante gefragt, was sie denn werden wolle. "Schornsteinfegerin“, antwortete sie jedes Mal. Die Tante lachte immer und fragte nach dem 365Grund. Das Mädchen antwortete dann selbstbewusst: "Weil ich dann in das Haus anderer Leute hineingehen darf. Wie ein Maikäfer." banheiro, Latona ouvia pouco depois um forte bater de asas. Ela temia toda vez que o chão estivesse coberto de água, mas isso não acontecia nunca. O chão, o espelho, a banheira estavam secos, quando a mulher deixava 0 banheiro. Eles até brilhavam, como se ela os tivesse limpado.

Latona não concluiu nenhuma formação profissional. Ela tateia sensitiva ao longo de cada caminho de formação e o deixa, antes que os sinos do casamento toquem. Ela não quer ser fracassada, pois a palavra fracasso soa heroica demais. Nenhuma prova era difícil para Latona. Seus dedos são hábeis, ela tem um bom ouvido e uma memória bem elástica. Ela passeia por dez jardins diferentes das formações, colhe em cada um flores úteis e não se sente cansada depois. Ela só não sabe que tipo de aposentada deveria se tornar. A fase da vida como aposentada é, com exceção daquelas depois da morte $e$ antes do nascimento, a mais longa, de modo que é preciso levá-la a sério. Essa questão a ocupa. Quando Latona era menina, era frequentemente questionada por uma tia sobre o que queria se tornar. Limpadora de chaminés, respondia ela toda vez. A tia sempre dava risada e perguntava pelo motivo. A menina respondia, então, confiante: "Porque assim eu posso entrar na casa das outras pessoas. Como um escaravelho." 
Ein länglicher Kasten mit Adressenkarteien 370 liegt neben ihrem Telefon. Manchmal blättern ihre Finger in Namen und Adressen, ohne eine bestimmte Person zu suchen. Ein Doppelname, ein vokalreicher Name, ein Nachname einer Frau, der einem männlichen 375 Name gleicht. Eine Kette von Namen entsteht, von der Latona aber nicht gefesselt wird. Die Namen erscheinen zwischen ihren Fingern und verschwinden wieder. Ich muss auch ein Teil dieser Kette gewesen sein.

Vor zehn Jahren war Latonas Zimmer noch zugestopft. Auf dem Schreibtisch lag ein Stapel frisch gewaschener Unterhosen und einer mit schwedischen Romanen. Sie hatte keine Zeit, Dinge in die Schublade hineinzutun und wieder 385 herausholen. Latona hat das Versteckspiel mit Schubladen nie verstanden. Ihr Schreibtisch hatte zwar auch Schubladen, aber Latona legte dort nur Briefe von Behörden hinein, die sie nie wieder sehen wollte.

390 Ihre Unordnung hatte damals eine heitere Leichtigkeit. Sie wusch nie ihre Teetasse ab, goss den nächsten kochendheißen Tee auf, bevor Schimmel in der Tasse wuchs. In der Wohngemeinschaft, in der sie während ihres 395Skandinavistik-Studiums lebte, galt es als peinlich, Dinge zu verstecken - vor allem die Dinge, die mit dem Unterleib zu tun hatten. Es gab sogar die Sitte, die Toilettentür nie ganz zu schließen, während man auf der Klobrille saß. 400Latona blieb allein in der Wohnung, in der ihre Wohngemeinschaft fünf Jahre lang gewohnt hatte. Ihr Vater kaufte sie für sie. Ihre
Uma caixa comprida com fichas de endereços fica ao lado do seu telefone. Às vezes seus dedos folheiam nomes e endereços, sem procurar por uma pessoa específica. Um nome duplo, um nome rico em vogais, um sobrenome de uma mulher que se assemelha a um nome masculino. Uma corrente de nomes surge, mas Latona não é cativada por ela. Os nomes aparecem entre seus dedos e desaparecem novamente. Eu também devo ter sido um pedaço dessa corrente.

Há dez anos o quarto de Latona ainda era abarrotado. Sobre a escrivaninha ficavam uma pilha de roupas íntimas recém-lavadas e uma de romances suecos. Ela não tinha tempo de guardar as coisas na gaveta e de voltar a tirálas. Latona nunca entendeu o jogo de escondeesconde com gavetas. Sua escrivaninha também tinha, sim, gavetas, mas Latona colocava ali dentro somente cartas de repartições públicas, que ela jamais queria voltar a ver.

Sua desordem tinha naquela época uma leveza divertida. Ela jamais lavava sua xícara de chá, despejava o próximo chá fervendo, antes de crescer bolor na xícara. Na república estudantil em que viveu durante seu curso de escandinavística era tido como embaraçoso esconder as coisas - sobretudo as coisas que tivessem a ver com o baixo-ventre. Havia até mesmo o costume de nunca fechar totalmente a porta do banheiro, enquanto se estivesse no assento. Latona ficou sozinha no apartamento em que os estudantes de sua república haviam morado por cinco anos. Seu pai o comprou 
Mitbewohner zogen aus und zogen nach München, Stockholm oder sogar nach Asien. 405 Latona bekommt ab und zu Briefe von einer ehemaligen Mitbewohnerin. „Ist es nicht wunderbar, dass der Opiumkrieg endlich zu Ende geht?", schrieb diese Freundin, die nach Peking übersiedelt war. „Viele meinen, dass er 410 schon seit hundert Jahren vorbei sei, aber das stimmt meiner Meinung nach nicht. Jetzt erst ist dieser Krieg zu Ende. Jetzt ist Tibet der Rausch, das Industrieland China muss nicht mehr die Rolle des Opiumrauchers spielen." 415 Latona schüttelt den Kopf. Wie kann diese Frau auf der anderen Seite der Erde allein leben? Dort stehen sie alle auf dem Kopf und es regnet aus der Erde.

Eines Tages wacht Latona mit dem Gefühl auf, 420 sie hätte verschlafen. Sie hat zu lange hinter einer Nacht verweilt, und zwar mehr als nur zwei, drei oder fünf Stunden zu lange. Es kommt ihr vor, als hätte sie über mehrere Jahreszeiten hinweggeschlafen. Sie blickt in 425 den Spiegel und sieht ein schmales Gesicht, mit Schnee gewaschen, die Fettschicht hat sich von der Haut gelöst, zarte Linien liegen um die Augen und auf der Stirn, die Mundöffnung ist dunkler geworden, die Augen feuchter, neue 430 Haare sind dicht gewachsen, sie glänzen silbern. para ela. Seus companheiros se mudaram de casa e mudaram para Munique, Estocolmo ou até mesmo para a Ásia. De vez em quando, Latona recebe cartas de uma então companheira de república. "Não é maravilhoso que a Guerra do Ópio finalmente chegue ao fim?", escreveu essa amiga que havia se mudado para Pequim. "Muitos acreditam que ela já tivesse acabado há séculos, mas na minha opinião isso não é correto. Somente agora essa guerra chega ao fim. Agora o Tibete é o torpor, o país industrial China não precisa mais fazer o papel do fumador de ópio. Latona balança a cabeça. Como essa mulher consegue morar sozinha do outro lado da Terra? Lá estão todos de ponta-cabeça e chove da Terra.

Um dia Latona acorda com a sensação de que teria dormido demais. Ela permaneceu tempo demais por trás de uma noite, aliás, mais do que apenas duas, três ou cinco horas a mais. Ela tem a impressão de ter dormido por várias estações do ano afora. Ela olha no espelho e vê um rosto estreito, lavado com neve, a camada de gordura se descolou da pele, linhas suaves estão ao redor dos olhos e na testa, a abertura da boca se tornou mais escura, os olhos mais úmidos, novos cabelos cresceram abundantes, eles brilham prateados. 


\section{Coronis}

Im Rauschzustand entdecke ich eine seltsame Geste der Alltagsgegenstände, sie tun so, als wären sie nicht sie selbst, als wären sie nur Gefäße für etwas anderes. Meine Geldbörse ${ }^{5}$ hat Münzen in ihrem Bauch, der Körper meines alten Füllers ist voller Tinte, meine blaue Teetasse hält die dunkle Flüssigkeit ruhig und auch das Fenster ist die vordere Seite eines Aquariums. Ich sehe eine Wasserlandschaft 10 darin. Draußen regnet es. Was befindet sich in dem Gefäß namens „Eiche"?

„Wir betrachten den Baum als Baum, während die Naturvölker in jedem Baum einen Wohnraum für die Baumgeister sehen", sagte 15 mir Latona.

„Betrachtest du den Baum wirklich als Baum? Kannst du das? Was ist ein Baum?"

„Ein Baum ist ein Hochgewächs mit festem Stamm, aus dem Äste wachsen, die sich in 20 laub- oder nadeltragende Zweige teilen."

„Du siehst den Baum ja gar nicht als Baum, sondern denkst nur, wie ein Baum sein soll."

Wenn die Klarheit des Rauschzustands einmal da sitzt, glänzen alle Gegenstände metallen 25 und werden elastisch wie Tuben. Verschiedene Farben quellen heraus: Tomatenmark, Zahnpasta, Schuhcreme und Senf. Jede Farbe endet, wo sie von einer anderen zurückgestoßen wird und nicht weiter kann.

${ }^{30}$ Zwischen zwei Farben gibt es keinen weißen Fleck mehr. Bald vermischen sie sich

\section{Coronis}

No estado-torpor descubro um gesto estranho dos objetos cotidianos, eles agem como se não fossem eles mesmos, como se fossem apenas recipientes para outra coisa. Minha carteira tem moedas em sua barriga, o corpo da minha velha caneta tinteiro está cheio de tinta, minha xícara azul de chá comporta tranquila o líquido escuro e também a janela é o lado da frente de um aquário. Eu vejo uma paisagem de água ali dentro. Lá fora chove. O que se encontra no recipiente chamado "carvalho"?

"Nós vemos a árvore como árvore enquanto os povos da natureza veem em cada árvore uma morada para os espíritos da árvore", me disse Latona.

"Você encara uma árvore realmente como árvore? Você consegue isto? O que é uma árvore?"

"Uma árvore é uma planta de estatura, com tronco rígido, do qual crescem galhos, que se separam em ramos carregados com folhagens ou agulhas."

"Você não vê a árvore de modo algum como árvore, apenas pensa como deve ser uma árvore."

Uma vez instalada a clareza do estado-torpor, todos os objetos brilham metálicos e se tornam elásticos como tubos. Diversas tintas-cores brotam para fora: massa de tomate, pasta de dente, graxa de sapato e mostarda. Cada tintacor termina onde é repelida por outra e não consegue continuar. Entre duas tintas-cores não há mais nenhuma mancha branca. Logo se misturam umas às outras e produzem 
miteinander und erzeugen neue, schwindelerregende Farben. Ich kenne dieses Bild aus meinem Atlas. Es ist die Karte mit der 35 Überschrift „Sprachen in Ostmitteleuropa und Südosteuropa".

"Tube" bedeute U-Bahn, lese ich in einem meiner Wörterbücher. Seitdem fühle ich mich halb flüssig, wenn ich in einer U-Bahn sitze.

40 Coronis sitzt in einer U-Bahn, ihr gegenüber sitzen zwei zähflüssige, einheimische Frauen, sonst ist kein Mensch zu sehen. Coronis rollt das Theaterprogramm zu einem Opernglas auf und spürt eine Lust, die Frauen dadurch zu 45 betrachten. Vor vierzig Jahren hätte sie das bestimmt noch gemacht. Jetzt aber ist sie kein Kind mehr, zumindest denken die anderen das. Der Zug hält an der Station St. Pauli, drei Männer in Lederjacken steigen ein. Der erste

${ }^{50}$ Mann hat ein schlammiges Gesicht, der Zweite besteht aus einer breiigen Masse und der Dritte ist so wässrig, dass er unscheinbar ist. Ihre Stimmen werden immer rauer, immer lauter, der Erste schreit fast, der Zweite spuckt und der 55 Dritte haut gegen die Tür, sie streiten über die Aufteilung des Geldes, das sie gerade gestohlen haben. Das immer lauter werdende Gespräch findet in einer ausländischen Sprache statt, keiner wird sie verstehen. Zufällig ist es 60 aber die Sprache, die Coronis' Mutter gesprochen hat. Coronis blättert in dem Theaterprogramm und versucht, sich hinter den gedruckten Buchstaben zu verstecken, während die Räuberstimmen in ihre Ohren 65 fließen. novas, vertiginosas tintas-cores. Eu conheço essa imagem do meu atlas. É o mapa com o título "Línguas no Leste da Europa Central e no Sul do Leste Europeu"

"Tube" significa metrô, leio em um dos meus dicionários. Desde então me sinto meio líquida, quando estou em um metrô.

Coronis está em um metrô, à sua frente estão duas mulheres viscosas nativas, além das quais não se vê mais nenhuma pessoa. Coronis enrola o programa de teatro para formar um binóculo de ópera e sente uma vontade de observar as mulheres por ali. Quarenta anos atrás ela ainda teria de certo feito isso. Mas agora ela não é mais criança, ao menos é o que pensam os outros. O trem para na estação St. Pauli, três homens em jaquetas de couro embarcam. O primeiro homem tem um rosto lamacento, o segundo se constitui de uma massa pastosa e o terceiro é tão aquoso, que é translúcido. Suas vozes se tornam cada vez mais roucas, cada vez mais altas, o primeiro quase grita, o segundo cospe e o terceiro esmurra a porta, eles brigam pela divisão do dinheiro que acabavam de roubar. $A$ conversa aumentando cada vez mais de volume acontece numa língua outra, ninguém a compreenderá. Mas, por coincidência, é a língua que a mãe de Coronis falava. Coronis folheia o programa de teatro e tenta se esconder atrás das letras impressas, enquanto as vozes dos ladrões fluem para seus ouvidos. 
„Ich schäme mich für meine Landsleute. Wie können sie bloß so primitiv sein!", schimpfte Coronis' Mutter manchmal, als sie noch lebte. Coronis lehnte die Tugend $a b$, sich für 70 Heimatgenossen zu schämen. Dennoch konnte sie kaum ruhig bleiben, wenn jemand hasserfüllt über ihr Volk redete. Das Volk! Es gibt nichts, was sie weniger interessierte als das Volk. Völker verdammen sich gegenseitig 75und jedes Volk ist doppelt belastet, weil es in jedem Volk auch noch "das Volk" gibt. Coronis kennt einige Arbeiter, hat aber noch nie mit einem Menschen aus dem Volk gesprochen, denn in dem Moment, in dem sie mit einem 80 spricht, ist er nicht mehr ein Teil des Volkes. Aber das Volk existiert scheinbar, denn es quält sie deutlich.

Kann man an Coronis' Gesicht sehen, dass sie die Sprache einer Diktatur versteht? Sie 85 versucht - im falschen Moment - heftig zu blinzeln und ansonsten gelangweilt in die Ferne zu blicken. Außerdem ist Coronis dick geschminkt, so dass das Dehnen und Zusammenziehen der Haut nicht ohne Weiteres $90 \mathrm{zu}$ sehen ist. Könnte trotzdem jemand sehen, dass die Sprache Coronis' Nerven trifft?

Plötzlich wirft einer der drei Männer einen scharfen Blick auf Coronis, als hätte er in ihrem Gesicht etwas wiedererkannt. Coronis lächelt 95 den beiden einheimischen Frauen $\mathrm{zu}$ und versucht dabei, in ihre Gesichter hineinzuschlüpfen. An der nächsten Station steigt eine Gruppe von Studenten ein und die drei Lederjacken steigen aus.
"Eu me envergonho pelos meus conterrâneos. Como podem ser assim tão primitivos!", insultava às vezes a mãe de Coronis, quando ainda vivia. Coronis recusou a virtude de se envergonhar por seus compatriotas. Apesar disso, ela quase não conseguia se manter tranquila, quando alguém falava cheio de ódio sobre seu povo. O povo! Não há nada que a interessasse menos do que o povo. Povos se condenam mutuamente e cada povo é sobrecarregado em dobro, porque em cada povo ainda há também "o povo". Coronis conhece alguns trabalhadores, mas nunca falou com uma pessoa do povo, pois no momento em que ela fala com uma, esta já não é mais parte do povo. Mas aparentemente o povo existe, pois é evidente que ele a atormenta.

É possível ver no rosto de Coronis que ela entende a língua de uma ditadura? Ela tenta no momento errado - piscar forte e, no mais, olhar entediada ao longe. Além disso, Coronis está com uma maquiagem carregada, de modo que o esticar e contrair da pele não pode ser visto assim sem mais. Apesar disso, alguém conseguiria ver que a língua atinge os nervos de Coronis?

De repente, um dos três homens lança um olhar incisivo sobre Coronis, como se ele tivesse reconhecido algo em seu rosto. Coronis sorri para as duas mulheres nativas e tenta com isso escapar para dentro de seus rostos. $\mathrm{Na}$ próxima estação, embarca um grupo de estudantes e os três jaquetas de couro desembarcam. 
100 „Das sind Fotos von den Männern, nach denen wir suchen. Haben Sie diese drei Männer an dem Abend gesehen?"

„Ja."

"Wo haben Sie sie gesehen?"

105 "In einer U-Bahn."

„Was haben Sie dort mit innen geredet?" "Nichts."

„Warum haben Sie nicht mit ihnen geredet?" „Weil ich sie nicht kenne."

110 „Aber Sie verstehen die Sprache, die die drei Männer gesprochen haben."

„Das ist kein Grund, mit jemandem zu reden."

Coronis verachtet die einheimischen Mädchen. In der Demokratie hat sich scheinbar ein 115 inzestuöses Verhältnis zwischen den Beamten und den Mädchen entwickelt. Wenn die Mädchen beim Schwarzfahren erwischt werden, beginnen sie, die Kontrolleure laut anzuschreien, mit ihnen zu schimpfen und 120 manchmal auch noch zu schluchzen, als wären die Kontrolleure ihre Eltern. Coronis kann den Anblick nicht ertragen, sie kann nicht verstehen, warum diese jungen Menschen ihre Gefühle auf den Teller legen und ihrem Feind 125 anbieten. Eine emotionale Reaktion verbindet Menschen miteinander. Von Coronis bekommt ein Bote der staatlichen Macht keine einzige Reaktion, keine Spucke, keine Tränen, keine zitternde Stimme, kein Schimpfwort. Coronis 130bleibt unfassbar und ungreifbar wie eine Abgemeldete.
"Estas são as fotos dos homens pelos quais procuramos. A senhora viu estes três homens nesta noite?"

"Sim."

"Onde a senhora os viu?"

"Em um metrô."

"O que a senhora falou ali com eles?"

"Nada."

"Por que a senhora não falou com eles?"

"Porque eu não os conheço."

"Mas a senhora entende a língua que falavam os três homens."

"Isso não é razão para falar com alguém."

Coronis desdenha das jovens nativas. $\mathrm{Na}$ democracia se desenvolveu aparentemente um comportamento incestuoso entre os funcionários públicos e as jovens. Quando as jovens são pegas viajando sem bilhete começam a vociferar com os controladores, a insultá-los e, às vezes, até a soluçar, como se os controladores fossem seus pais. Coronis não consegue suportar a cena, ela não consegue entender por que essas jovens pessoas colocam seus sentimentos sobre 0 prato e oferecem a seu inimigo. Uma reação emocional liga as pessoas umas às outras. De Coronis não recebe um mensageiro do poder estatal nem uma única reação, nenhum cuspe, nenhuma lágrima, nenhuma voz trêmula, nenhum palavrão. Coronis permanece intocável e inatingível como uma sem-registro. 
„Worüber haben die Männer miteinander gesprochen?"

„Ich weiß es nicht mehr."

135

„War der Inhalt des Gesprächs so schrecklich, dass Sie ihn verdrängen mussten?"

„Ich höre fremden Leuten nicht zu, wenn ihr Thema nicht interessant ist."

„Bei welchen Wörtern haben Sie festgestellt, 140 dass das Thema Sie nicht interessiert?"

„Ich weiß es nicht mehr. Von irgendeiner Uhrzeit, dem Hauptbahnhof und den schlafenden Kindern zu Hause oder so etwas haben sie gesprochen. Ich bin aber nicht 145 sicher."

„Welche Uhrzeit haben sie genannt?"

Coronis hatte keinen Grund, die drei Verbrecher zu verteidigen. Sie hatte aber auch nicht die Angewohnheit, einem Polizisten alles $150 \mathrm{zu}$ erzählen, was sie gesehen zu haben glaubte. Ihr fehlte das Verlangen nach einer Wahrheit, die an und für sich einen Wert haben sollte.

Eine Mücke fliegt quer durch Coronis' 155 Blickfeld. Als sie den winzigen Flieger fangen will, ist er schon mit der Luft verschmolzen. Coronis sitzt im Abendlicht auf dem Balkon und liest. Schon wieder springt eine freche Mücke in ihr Blickfeld. Coronis hält den Atem 160 an und horcht, die Abendstille fällt auf den

Balkon. Die Mücke ist weg. Einige Sekunden später huscht wieder ein winziger Schatten vorbei. Es ist vielleicht gar keine Mücke. Ein zerbrochener Teil eines Buchstabens? Staub 165im Auge? Coronis hält inne, kehrt vorsichtig zu der Buchseite zurück, da taucht die Scheinmücke wieder auf. Der fliegende Scheinschatten befindet sich nicht in der Luft,
"Sobre o que os homens falaram entre si?

"Eu não sei mais."

"O conteúdo da conversa era tão terrível, que a senhora precisou recalcá-lo?"

"Eu não escuto estranhos com atenção se seu assunto não é interessante."

"Em quais palavras a senhora constatou que o assunto não a interessa?"

"Eu não sei mais. Sobre algum horário, a estação principal e as crianças dormindo em casa ou algo assim eles falaram. Mas eu não tenho certeza."

"Qual horário eles mencionaram?"

Coronis não tinha nenhum motivo para defender os três criminosos. Mas ela também não tinha o costume de contar a um policial tudo o que acreditava ter visto. Falta a ela o anseio por uma verdade que devesse ter um valor em e por si.

Uma mosca atravessa o campo visual de Coronis. Quando ela quer apanhar o voador minúsculo, ele já se fundiu com o ar. Coronis está sentada à luz da noite na varanda e lê. Novamente volta a saltar uma mosca atrevida em seu campo visual. Coronis prende a respiração e fica à espreita, o silêncio da noite cai sobre a varanda. A mosca se foi. Alguns segundos mais tarde, uma sombra atrevida volta a se esgueirar. Talvez não seja mosca alguma. Um pedaço partido de uma letra? Poeira nos olhos? Coronis se detém, retorna cuidadosa para a página do livro, ali a moscailusão emerge de volta. A sombra-ilusão voadora não se encontra no ar, mas sim no 
sondern in Coronis' Augäpfeln, es ist ein Riss 170 in ihrer Sehkraft.

„Das kommt vom Alter", sagt der Augenarzt.

„Die Scheinmücke kommt vom Alter? Und wo liegt die Stadt, die ,Alter' heißt?"

„Das sind keine Tiere, das ist ein körperlicher 175 Mangel."

„Es ist schön, jedes Jahr ein Insekt mehr im Körper zu haben: eine Grille im Herzen, eine Heuschrecke in den Nerven und einen Nachtfalter im Hals."

180 Coronis stellt sich sich selbst wie ein Wohnhaus für unsichtbare Insekten vor. Der Arzt setzt eine Probebrille auf Coronis' Nase und zeigt auf ein Plakat, auf dem Reihen von Buchstaben zu sehen sind. Sie sehen aus wie 185 konkrete Poesie.

„Was für einen Buchstaben sehen Sie dort?" Coronis sieht ein $\mathrm{O}$, aber mit einer anderen Brille sieht sie ein $Q$, mit einer dritten ein $G$.

„Was sehen Sie nun?", fragt der Arzt.

190 Coronis antwortet: „Ich sehe jedes Mal was anderes. Durch häufigen Brillenwechsel Mehrdeutigkeit erleben, soll das der Sinn einer Brille sein?"

„Frauen, die als Mädchen gute Augen hatten, 195 haben Probleme mit Brillen, weil sie sie nur als Symbol für das Altern wahrnehmen. Aber denken Sie doch daran, dass es auch viele kleine Kinder gibt, die Brillen tragen müssen", sagt der Arzt.

200 „Ein Leben ohne Brillen ist langweilig", antwortet Coronis fröhlich. globo ocular de Coronis, é um rasgo em sua vista.

"Isso é da idade", diz o oftalmologista.

"A mosca-ilusão é da idade? E onde fica a cidade que se chama 'idade'?"

"Não são animais, é uma deficiência corporal."

"É bonito ter a cada ano um inseto a mais no corpo: um grilo no coração, um gafanhoto nos nervos e uma mariposa-noite na garganta."

Coronis imagina a si mesma como uma morada para insetos invisíveis. O médico coloca uns óculos-teste sobre o nariz de Coronis e aponta para um quadro no qual se veem fileiras de letras. Elas parecem poesia concreta.

"Que letra a senhora vê ali?"

Coronis vê um $\mathrm{O}$, mas com outros óculos ela vê um $Q$, com um terceiro um $\mathrm{G}$.

"O que a senhora vê afinal?", pergunta o médico. Coronis responde: "Eu vejo cada vez algo distinto. Pela constante troca de óculos vivenciar a pluralidade de significados, deve ser esse o sentido dos óculos?"

Mulheres que tinham bons olhos quando jovens têm problemas com óculos, porque elas os encaram apenas como símbolo da idade. Mas pense que há muitas crianças pequenas que também precisam usar óculos", diz o médico. "Uma vida sem óculos é entediante", responde Coronis feliz. 
Bei der Preisverleihung tat Coronis so, als hätte sie den Gedichtband noch nicht gelesen, der den Preis bekam. In der Tat konnte Coronis 205 sich nicht einmal an die Anfangszeile des ersten Gedichtes erinnern. Sie hatte das Gedicht schon vor zehn Jahren geschrieben, durfte es damals in ihrem Land aber nicht veröffentlichen.

210 Die Preisverleihung fand in einem Hotel statt. Den Literaturpreis, dessen lange Bezeichnung kaum jemand bis zum Ende aussprechen konnte, hatte eine große Papierfabrik gestiftet. Coronis dachte bei dem Wort "Preis" sofort an 215Geld, das sie zahlen muss, aber nicht an das, was sie bekam. Errötete Gesichter füllten den Saal. Einige Münder öffneten sich, um Coronis Fragen zu stellen:

"Genießen Sie die Freiheit bei uns?"

$220 \quad$ „Schreiben Sie mit einem Computer?"

Oft erinnerte sich Coronis an die Boten der Geheimpolizei, die ihr absichtlich dumme Fragen gestellt hatten, um zu spionieren.

„Sind Sie verheiratet? Ich kenne auch 225 jemanden, der im Kommunismus gelebt hat."

„Was für ein Auto fahren Sie?"

„Warum gibt es so viele kleine Hunde in Ihrer Heimatstadt? Ich war letztes Jahr dort. Ich sah so viele Hunde auf der Straße, unglaublich 230 viele. Nein, nein, kein Dackel, auch kein Pudel. Sie waren nicht reinrassig und hatten kein Halsband."
$\mathrm{Na}$ entrega do prêmio Coronis agia como se ainda não tivesse lido o volume de poemas que recebeu o prêmio. De fato, Coronis não podia se lembrar das linhas iniciais do primeiro poema. Ela tinha escrito o poema já há dez anos, mas não teve permissão naquela época para publicá-lo em seu país.

A entrega do prêmio aconteceu num hotel. $O$ prêmio de literatura, cuja longa denominação quase ninguém conseguia falar até o fim, tinha sido financiado por uma grande fábrica de papel. Coronis pensava com a palavra "prêmio" imediatamente em dinheiro que ela tem de pagar, mas não naquilo que recebia. Rostos avermelhados preenchiam o salão. Algumas bocas se abriam para fazer perguntas a Coronis:

"A senhora aprecia a liberdade em nosso país?"

"A senhora escreve com um computador?" Frequentemente Coronis se lembrava dos mensageiros da polícia secreta que tinham feito a ela perguntas estúpidas, de propósito, para espionar.

"A senhora é casada? Eu também conheço alguém que viveu no comunismo."

"Que carro a senhora dirige?"

"Por que há tantos cães pequenos em sua cidade natal? Eu estive lá no ano passado. Eu vi tantos cães na rua, inacreditavelmente muitos. Não, não, nenhum dachshund, e também nenhum poodle. Eles não eram raça pura e não tinham coleira." 
Coronis bekommt eine Karte, darauf steht ein schwarz eingerahmter Text, das Datum und 235 der Ort einer Beerdigung. Ein weiblicher Name steht neben einem schwarzen Kreuz. Coronis weiß nicht sofort, wer die Verstorbene ist. Bald kommt ihr eine halbgelähmte Frau in den Sinn, bei der sie einige Wochen übernachtet hatte, 240 als sie in diese Stadt übersiedelte. Coronis weiß noch, dass diese Frau einen Pianisten verehrte der aus demselben Dorf stammte wie Coronis' Mutter. Leda war der Name dieser Frau. Coronis war erst einige Monate in der 245 Stadt, wanderte von Bekannten zu Bekannten, hatte noch keine Arbeitsstelle. Sie wollte im Lager eines Kaufhauses arbeiten. Als Leda das hörte, war sie entsetzt und sagte: „Eine Dichterin kann nicht in einem Lager arbeiten."

250 Coronis erwiderte: „Ich kenne viele Dichter, die als Müllmänner arbeiten."

„Wie können sie dann noch Dichter sein?"

„Durch Dichten eben. Sie haben es nicht nötig, durch Ablehnung eines einfachen Jobs zu 255 beweisen, dass sie Dichter sind."

Leda fand, Coronis müsse sich unbedingt Unterstützung vom Staat holen, denn der Staat ist das Vaterunser. Für Coronis war es unangenehm, sich den Staat mit väterlichem 260 Fleisch vorzustellen. So stellte sie sich den Staat auch nach ihrer Emigration weiter als eine schwarze Wolke vor. Man kann den Staat ausnutzen, so wie ein Bauer das Regenwasser ausnutzt. Man sollte aber nicht glauben, dass 265 der Regen die Absicht habe, den Bauern zu helfen.

Wer würde sich nach Ledas Tod an sie
Coronis recebe um cartão, ali está emoldurado em preto um texto, a data e o local de um enterro. Um nome feminino está perto de uma cruz preta. Coronis não sabe de imediato quem é a falecida. Logo the vem à mente uma mulher semiparalisada, na casa da qual tinha pernoitado algumas semanas quando se mudou para essa cidade. Coronis ainda se lembra que essa mulher venerava um pianista vindo do mesmo vilarejo da mãe de Coronis. Leda era o nome dessa mulher. Coronis estava somente há alguns meses na cidade, vagava de conhecidos em conhecidos, ainda não tinha um trabalho. Ela queria trabalhar no depósito de uma loja de departamentos. Quando Leda ouviu isso, ficou horrorizada e disse: "uma poeta não pode trabalhar em um depósito".

Coronis retrucou: "conheço muitos poetas que trabalham como lixeiros."

"E como eles ainda conseguem ser poetas?"

"Justamente pelo fazer poético. Eles não têm necessidade de provar que são poetas pela recusa de um trabalho simples."

Leda achava que Coronis deveria de todo modo buscar apoio do Estado, pois o Estado é - Pai-Nosso. Para Coronis era desagradável imaginar o Estado com carne paterna. Assim, ela continuava a imaginar o Estado também após sua emigração como uma nuvem negra. Podemos nos aproveitar do Estado, assim como um homem do campo se aproveita da água da chuva. Mas não deveríamos acreditar que a chuva tem a intenção de ajudar o homem do campo.

Quem iria se lembrar de Leda após sua 
erinnern? Sie hatte weder Kinder noch Geschwister. Sie war aus dem Stammbaum 270 der Familie gestürzt.

Auch Coronis hatte keine Nachkommen und würde später zu den Toten gehören, die in keiner Familienchronik vorkommen. Sie findet es verdächtig, wenn die Menschen von ihren 275 Vorfahren oder von ihren Kindern erzählen. Deshalb schreibt sie auch keinen Roman, denn dort sind die Menschen nur durch Blut oder durch Liebschaften miteinander verbunden.

280 Coronis sucht nach ihren Schamlippen. „Schäm dich", sagte ihre Mutter manchmal zu ihr, wenn sie nach dem Baden nackt vor einem Spiegel stand. Man schämt sich nicht in Richtung des Himmels, sondern in Grund und 285 Boden. Die Beschämung zieht den Menschen nach unten, Coronis sucht auf dem Boden nach ihren Schamlippen, sie sieht plötzlich eine Öffnung der Erde. Das sind große feuchte Lippen, die sich pausenlos bewegen, sie sind 290 zum Sprechen da, zum Lispeln und zum Lallen.

Bei Coronis haben Sucht und Sehnsucht nie aufgehört. Sie bekommt nachts unter bestimmten Bedingungen, die man aber in 295 keine chemische Formel fassen kann, Anfälle.

Zuerst fühlt es sich so an, als würden Schmerzen auftauchen. Aber sie kommen nicht. Stattdessen öffnet sich ein Sumpfgebiet, ein unwiderstehliches Verlangen nach einer 300 anderen Person. Coronis möchte in die tiefere

Uhrzeit der Nacht hineinkriechen und eine Person anrufen, ihre Schleimhaut auf den morte? Ela não tinha filhos, nem irmãos. Ela havia despencado da árvore genealógica da família.

Também Coronis não possuía descendentes e pertenceria mais tarde aos mortos que não aparecem em nenhuma crônica familiar. Ela acha suspeito quando as pessoas contam sobre seus ancestrais ou sobre seus filhos. Por isso ela também não escreve um romance, pois lá todas as pessoas estão ligadas umas às outras apenas pelo sangue ou por casinhos amorosos.

Coronis procura por seus lábios-vergonha. "Que vergonha você", dizia sua mãe às vezes a ela, quando, depois do banho, ficava nua diante do espelho. Não nos envergonhamos em direção ao céu, mas sim ao solo e ao chão. Envergonhar-se puxa as pessoas para baixo, Coronis procura no chão por seus lábiosvergonha, ela vê de repente uma fenda na terra. Esses são lábios grandes e úmidos que se movimentam sem pausa, eles estão ali para falar com a língua presa e balbuciar.

Em Coronis nunca cessaram o vício e a saudade. Ela tem ataques à noite sob determinadas condições que não se podem exprimir por nenhuma fórmula química. No início, é como se fossem surgir dores. Mas elas não vêm. Ao invés disso, se abre um pântano, um anseio irresistível por uma outra pessoa. Coronis gostaria de se enfiar no horário mais profundo da noite e ligar para uma pessoa, pressionar sua mucosa no fone, picar o parceiro invisível de conversa com 
Hörer pressen, mit kleinen Nadeln den unsichtbaren Gesprächspartner stechen, bis 305 der Zucker ihres Gefühls anbrennt und bitter wird. Eine krankhafte Sucht nach Menschen zwingt Coronis, sich auf eine schutzlose Person zu stürzen, um ihr zu schaden. Die sexuelle Lust hingegen hat für sie etwas 310 Autistisches. Sie braucht keine andere Person, sondern eine Sprache. Coronis erlebt den fleischlichen Höhepunkt beim Schreiben. Es ist sieben Uhr morgens. Ein Spatz sitzt auf einem Ast und beobachtet sie durch eine 315 Fensterscheibe.Der Spatz, die Geheimpolizei, sieht, wie die Frau mit einer altmodischen Schreibmaschine schreibt und dabei erregt wird. Coronis achtet nicht auf den Vogel, ahnt nicht, was später mit ihr passieren wird.

320 Nach der Emigration heiratete Coronis einen Einheimischen. Schon mehrmals sagte er, sie solle nicht das Wort "Einheimische" benutzen, es höre sich an, als spräche eine Ethnologin von den Wilden.

325 Coronis' Mann sagt, er würde gerne Kunst machen, müsse aber Comicstrips zeichnen, um sein Brot zu verdienen. Ein Wort wie "Brot" verunsichert Coronis, denn im Kommunismus gab es keine christliche Symbolik. Vermutlich 330 bedeutete das Wort etwas Heiliges. Für das heilige Brot also unterdrückt ihr Mann seine Lust zur Kunst und zeichnet die Strips. Er will sich aufopfern, vielleicht ist es eine Art Ritual. „Wenn du deine Bilder malen willst, geh doch 335malen. Keiner verbietet dir das."

„Ich kann nicht. Ich muss unser Brot verdienen." pequenas agulhas até que o açúcar de seu sentimento se queime e se torne amargo. Um vício doentio por pessoas força Coronis a se lançar sobre um indivíduo indefeso para ferilo. O prazer sexual, por outro lado, tem para ela algo de autista. Ela não precisa de outra pessoa, mas de uma linguagem. Coronis experimenta o clímax carnal ao escrever. São sete horas da manhã. Um pardal pousa em um galho e a observa pela vidraça de uma janela. O pardal, a polícia secreta, vê como a mulher escreve com uma máquina de escrever antiquada e fica excitada com isso. Coronis não presta atenção no pássaro, não pressente o que acontecerá com ela mais tarde.

Depois de sua emigração, Coronis se casou com um nativo. Já várias vezes ele disse que ela não deveria usar a palavra "nativo", isso soava como se uma etnóloga falasse dos selvagens.

O marido de Coronis diz que gostaria de fazer arte, mas precisa desenhar tiras para ganhar seu pão. Uma palavra como "pão" deixa Coronis em dúvida, pois no comunismo não havia simbologia cristã. Supostamente a palavra significava algo sagrado. Pelo pão sagrado, então, seu marido reprime seu desejo pela arte e desenha tiras. Ele quer se sacrificar, talvez isso seja um tipo de ritual.

"Se você quer pintar seus quadros, vá pintar então. Ninguém Ihe proíbe".

"Eu não posso. Eu preciso ganhar nosso pão." 
„Aber du kannst doch abends und am Wochenende malen."

„Du verstehst mich nicht. Ich kann nicht 340 malen, wenn ich Geld verdienen muss."

Coronis bekommt plötzlich Angst vor dem Wort Geld, denn es wird so ausgesprochen, als würde eine geheimnisvolle Logik dahinterstecken, die ein Außenstehender nicht 345 verstehen kann. Coronis erinnert sich an ein altertümliches Ritual, in dem ein neugeborenes Kind auf eine Straße ausgesetzt wird, damit die bösen Geister glauben, das Kind sei nicht begehrenswert. Vielleicht verachtete ihr Mann 350 das Geld, damit die bösen Geister nicht bemerken, dass es inm viel bedeutet.

„Ich muss doch Geld verdienen, auch wenn ich keine Lust dazu habe", wiederholt der Mann.

„Kannst du so klar trennen, was du willst und 355was du musst? Ich meine, du glaubst, dass du Geld verdienen müsstest, aber du musst doch gar nicht, du willst doch Geld verdienen. Aber du willst nicht zugeben, dass du es willst. Du sagst bloß, das sei dein Muss, damit du sagen 360 kannst, dass du etwas anderes willst, weil du denkst, du musst Kunst wollen."

Ihr Mann verachtet Coronis' Unfähigkeit, eine geläufige Rhetorik des erwachsenen Kapitalismus zu verstehen, aber er verzeiht ihr 365 auch das. Für ihre Fehler trägt die berühmte Diktatur die Schuld, sie kann nichts dafür. Dort lernt man nämlich nicht, wollen von müssen zu unterscheiden, denkt der Stripzeichner.

Bei Comicstrips muss man keine Angst vor 370 Übertreibung haben. Coronis' Mann stößt
"Mas você pode pintar à noite e nos fins de semana."

"Você não me entende. Eu não posso pintar, se eu preciso ganhar dinheiro."

Coronis fica de repente com medo da palavra dinheiro, pois é falada de tal modo, como se escondesse uma lógica misteriosa por trás de si que alguém de fora não consegue compreender. Coronis se recorda de um ritual arcaico, no qual uma criança recém-nascida é colocada na rua para que os maus espíritos acreditem que a criança não seja cobiçável. Talvez seu marido desdenhe do dinheiro, para que os maus espíritos não percebam que significa muito para ele.

"Eu preciso sim ganhar dinheiro, mesmo que eu não tenha vontade", repete o marido.

"Você consegue separar de modo tão claro o que quer e o que precisa? Eu acho que você acredita que precisa ganhar dinheiro, mas não precisa de maneira alguma, você quer sim ganhar dinheiro. Mas você não quer admitir que você o quer. Você só diz que isso é sua necessidade para que possa dizer que quer outra coisa, porque você pensa que precisa querer arte."

Seu marido desdenha da incapacidade de Coronis de entender uma retórica corrente do capitalismo adulto, mas ele a perdoa também por isso. Pelos seus erros carrega a culpa a famosa ditadura, ela não pode fazer nada. É que lá não se aprende a diferenciar querer de precisar, pensa o cartunista.

Nas tiras não é preciso ter medo do exagero. $O$ marido de Coronis enfia por descuido um 
versehentlich einen BBQ-Dolch in den Bauch seiner Frau, spürt ein Kind im Bauch und heult. Ein Springbrunnen von Tränen mitten in einem Blutteich. Aber es ist noch nicht zu spät, er 375 kann das Kind noch retten. Der Mörder begießt die Leiche mit Parfüm Chanel-Nummer-Fünf und bedeckt das Fleisch mit Küssen. Dann öffnet sich eine Automatiktür zwischen den Beinen der toten Frau und ein Kind kriecht 380heraus. Comicstrips schwimmen in den elektrischen Farben der Mythen.

Der Stripzeichner zündet sich eine Zigarette an, nimmt einen Papierfetzen in die Hand und zeichnet einfach einen weißen Vogel. 385 Manchmal muss er zwischendurch kleine

Figuren zeichnen, wie man eine Notiz macht, weiß aber selber nicht, was er damit notieren will. Er schlägt den Vogel mit einem Pinsel, die Federn werden braun befleckt. Der Vogel 390 zwitschert, deine Frau braucht keinen Mann, um verliebt zu sein. Dann flattert er und versucht, vom Papier wegzufliegen. Der Stripzeichner könnte ihm einen Käfig zeichnen, aber es ist besser, wenn er wegfliegt. Sonst 395 könnte der geschwätzige Vogel noch mehr ärgerliche Dinge über seine Frau erzählen.

Coronis liest dem Publikum aus inrem neuen Buch vor. Die ersten fünf Minuten kann die Stimmung im Raum spritzig sein, dann wird ein ${ }^{400}$ Teil des Publikums matt, aber einige belebte Häute atmen Coronis' Zeilen. Coronis blinzelt immer heftiger, sie sieht die Zeilen nicht klar, sie denkt an die Kassenbrille, die jetzt zu Hause auf dem Schreibtisch liegt. „Selber schuld. Du 405 hättest die Brille mitnehmen sollen", würde ihr Mann in dieser Situation sagen. Er benutzt espeto de churrasco na barriga de sua mulher, sente uma criança na barriga e berra. Um chafariz de lágrimas em meio a uma lagoa de sangue. Mas ainda não é tarde demais, ele ainda pode salvar a criança. $O$ assassino borrifa o corpo com perfume Chanel Número Cinco e cobre a carne com beijos. Então se abre uma porta automática entre as pernas da mulher morta e uma criança engatinha para fora. As tiras nadam nas elétricas tintas-cores dos mitos.

O cartunista acende um cigarro, pega um pedaço de papel na mão e desenha simplesmente um pássaro branco. Às vezes ele precisa, entre uma coisa e outra, desenhar pequenas figuras, como quem faz uma anotação, mas ele mesmo não sabe o que quer anotar com aquilo. Ele acerta o pássaro com um pincel, as penas são manchadas de marrom. $O$ pássaro gorjeia, tua mulher não precisa de um homem para estar apaixonada. Então ele esvoaça e tenta voar para fora do papel. O cartunista poderia Ihe desenhar uma gaiola, mas é melhor que saia voando. Senão o pássaro linguarudo poderia contar ainda mais coisas irritantes sobre sua mulher.

Coronis lê para o público de seu novo livro. Nos primeiros cinco minutos a atmosfera na sala pode estar animada, então uma parte do público fica abatida, mas algumas peles vivazes respiram as linhas de Coronis. Coronis pisca cada vez mais forte, ela não vê as linhas claramente, ela pensa nos óculos baratos do seguro, que agora estão em casa sobre a escrivaninha. "Culpa sua. Você deveria ter trazido os óculos", diria seu marido nessa 
gerne den religiösen Begriff der Schuld. „Was nützt es mir aber, über Schuld, Sünde, Sühne und Bestrafung nachzudenken? Ich will bloß 410 meine Sehkraft." Die Beleuchtung im Raum stimmt nicht. Die Buchseiten werden immer heller und die Schrift verschwindet im Licht. Bitte mehr Dunkelheit, damit ich lesen kann!

„Als sie zum ersten Mal bei uns auf einer 415Tagung war - es ist inzwischen vielleicht schon zwanzig Jahre her -, war sie noch eine junge Frau. Sie hatte damals bereits zwei Bücher veröffentlicht, ihr Gesicht war aber noch nicht so schön wie heute", erzählte mir die Leiterin 420 des Kulturzentrums. Ich war eine Liebhaberin von Coronis' Literatur.

„Ich bewundere ihre Literatur seit zehn Jahren. Ihre Sätze haben etwas Rauschhaftes."

Ich hatte mit „rauschhaft" eigentlich ein 425 konkretes Rauschmittel gemeint, das in Coronis' Sätzen materiell zu spüren ist. Aber so direkt wollte ich das nicht sagen.

Die Leiterin holte aus dem Büroschrank ein Fotoalbum und blätterte darin. Auf einem 430 verblassten Foto sah ich Coronis' Gesicht, rund und glatt, ein spuckendes Gesicht, ein Hinwerfen und kein Hinschauen, ein Rennen und Heulen ohne Berechnung. Wie oft bei jungen Menschen verrät die äußere 435 Souveränität ihre Unsicherheit. Heute sieht Coronis nicht mehr unreif und verschlossen aus. Ich kann ihre redefeuchten Lippen nicht vergessen, die ich vor Kurzem während ihrer situação. Ele gosta de utilizar o conceito religioso da culpa. "Mas de que me adianta pensar em culpa, pecado, penitência e castigo? Eu só quero minha visão." A iluminação na sala não estava adequada. As páginas do livro ficam cada vez mais iluminadas e a escrita desaparece na luz. Por favor, mais escuridão para que eu possa ler!

"Quando ela esteve pela primeira vez entre nós para um congresso - já faz nesse meio-tempo talvez uns vinte anos - ela ainda era uma mulher jovem. Ela já tinha publicado naquela época dois livros, mas seu rosto ainda não era tão belo como hoje", me contou a diretora do centro cultural. Eu era uma amante da literatura de Coronis.

"Eu admiro sua literatura há dez anos. Suas frases têm algo de entorpecedor."

Eu tinha me referido com "entorpecedor" na verdade a uma substância-torpor concreta, que pode ser materialmente sentida nas frases de Coronis. Mas eu não quis dizer isto assim tão diretamente.

A diretora pegou do armário do escritório um álbum de fotografias e o folheou. Numa foto empalidecida vi o rosto de Coronis, redondo e liso, um rosto cuspindo, um atirar e não mirar, um correr e berrar sem cálculo. Com que frequência a soberba exterior denuncia nas pessoas jovens sua insegurança. Hoje Coronis não parece mais imatura e fechada. Não consigo esquecer seus lábios úmidos da fala que observei há pouco no decorrer de sua leitura. Seus olhos estavam bem abertos, ela 
${ }_{440}$ Lesung beobachtet habe. Ihre Augen waren weit geöffnet, sie erlaubte auch unartigen und angriffssüchtigen Menschen Zutritt. Das jugendliche Fleisch an den Wangen, das einmal Beleidigung und Verstummen darstellen sollte, war verschwunden. Vielleicht waren ihre 445 geschliffenen Sätze das, was jahrelang ihr

Gesicht geklopft und geformt hat.

Coronis wird oft von Passanten betrachtet. Die Augen der Dorfbewohner starren sie an. Die Augen der Großstädter starren sie ebenso an: in Straßenbahnen, in Restaurants, in ${ }^{450}$ Kaufhäusern. Das ist insofern rätselhaft, als es bei ihr nichts Auffälliges gibt, was man als fremdländisch empfinden könnte.

„Wo kommen Sie her?", fragen alle jungen Gemüsehändler, wenn sie Coronis sehen. Die 455 Vorfahren dieser Männer stammen aus einem anderen Land. Coronis versucht zu lächeln. Es ist etwas Natürliches, wenn junge Menschen solche Fragen stellen. Natürlichkeiten können Coronis aber nervös machen.

460 „Wo kommen Sie her?", wiederholen die Männer ihre Frage, als hätten sie ein Recht, das zu erfahren. Man darf natürlich nicht jedem Kunden diese Frage stellen, einen einheimischen Mann zum Beispiel darf man 465 nicht einfach fragen, wo er geboren wurde.

Aber eine Frau, die sich noch nicht definiert hat, darf man alles fragen.

Coronis versucht wie andere Frauen, diese 470Belästigung in eine Anerkennung ihrer Anziehungskraft umzudeuten. Bei manchen Menschen ist die Frage nach der Herkunft die einzige erotische Frage, die sie noch in der Öffentlichkeit stellen dürfen. permitia acesso também às pessoas mal educadas e viciadas em ataque. A carne jovem nas bochechas, que outrora deveria apresentar ofensa e emudecimento, tinha desaparecido. Talvez as suas frases polidas tivessem ao longo dos anos batido e modelado seu rosto.

Coronis é frequentemente observada por passantes. Os olhos dos moradores do vilarejo fitavam-na. Os olhos dos da cidade grande fitavam-na da mesma forma: nos bondes, nos restaurantes, nas lojas de departamento. Isso é tão mais enigmático, pois nela não há nada que chame atenção, algo que se possa sentir como alheio ao lugar.

"De onde a senhora vem?", perguntam todos os jovens vendedores de legumes, quando veem Coronis. Os ancestrais desses homens provêm de um outro país. Coronis tenta sorrir. É algo natural quando pessoas jovens fazem tais perguntas. Mas naturalidades podem deixar Coronis nervosa.

"De onde a senhora vem?", os homens repetem sua pergunta, como se tivessem um direito de saber disso. Não se pode naturalmente fazer essa pergunta para qualquer cliente, para um homem nativo, por exemplo, não se pode simplesmente perguntar onde ele nasceu. Mas para uma mulher que ainda não se definiu, se pode perguntar tudo.

Coronis tenta como outras mulheres ressignificar este assédio em um reconhecimento de seu poder de atração. Para algumas pessoas a pergunta sobre a origem é a única pergunta erótica que ainda podem fazer em público. 
475 Eines Tages erzählt Coronis der Leiterin des Kulturzentrums bei einer Tasse Kaffee von diesem Problem, das sie im Alltag belastet. Ich möchte Tomaten kaufen dürfen, ohne nach der Herkunft gefragt zu werden."

480 Die Leiterin fühlt sich angegriffen.

„Warum darf man Ihnen keine Fragen stellen? Ich glaube, das ist eine gesunde Neugierde." Coronis schweigt. In einer Demokratie ist es ein Tabu, jemandem Fragen zu verbieten.

485 Die Leiterin gehört zu den wohlhabenden Kulturmenschen, die nichts mehr mit dem Alltag auf der Straße zu tun haben. Hinter dem Zeitungspapier ärgert sie sich über Diskriminierungen jeder Sorte, Verfall der 490 Sprache, Beschneidung der Kulturgelder, aber ihr Körper wird nie auf einer Straße ausgesetzt, auf der rohe Stimmen herumfliegen. Sie hat ihren Körper bereits abstrahiert und in Positionsbezeichnungen transportiert wie 495 Mitglied eines Institutes und einer Familie.

Wenn die Leiterin des Kulturzentrums einen Gemüseladen betritt, fragt der Verkäufer nicht, woher sie kommt. Denn bei ihr ist schon gänzlich vergessen worden, dass sie überhaupt 500 irgendwoher gekommen sein könnte.

„Du hast dich noch nie über Nabokov geäußert. Wäre das nicht ein Autor für dich? Schließlich kommt er auch aus dem Osten."

„Was meinst du mit dem Osten?"

505 „Ich sollte lieber Europa sagen. Von mir aus muss es nicht unbedingt Nabokov sein. Willst du nicht etwas über Joyce oder Proust sagen? Musil ginge auch. Das wäre gut für das Sonderheft zu den Giganten der europäischen
Um dia Coronis conta à diretora do centro cultural durante uma xícara de café sobre este problema que a atormenta no cotidiano.

"Eu gostaria de poder comprar tomates sem ser questionada pela origem."

A diretora sentiu-se atingida.

"Por que não se pode lhe fazer perguntas? Eu acho isso uma curiosidade saudável."

Coronis silencia. Em uma democracia é um tabu proibir perguntas a alguém.

A diretora pertence às pessoas abastadas da cultura, que não têm mais nada a ver com o cotidiano na rua. Atrás do papel de jornal ela se enfurece com discriminações de todo tipo, decadência da língua, corte de verbas para cultura, mas seu corpo nunca será abandonado em uma rua, pela qual voam vozes cruas. Ela já abstraiu seu corpo prontamente e o transportou para designações de posição como membro de um instituto e de uma família. Quando a diretora do centro cultural entra numa quitanda, o vendedor não pergunta de onde ela vem. Pois, no caso dela, já foi totalmente esquecido que sequer pudesse ter vindo de algum lugar.

"Você nunca se expressou sobre Nabokov. Esse não seria um autor para você? Afinal ele também vem do Leste."

"O que você quer dizer com Leste?"

"Seria melhor dizer Europa. Por mim não precisa ser necessariamente Nabokov. Você não quer dizer algo sobre Joyce ou Proust? Musil serviria também. Isso seria bom para 0 caderno especial sobre os gigantes da 
510 Literatur."

„Ich möchte keinen Großvater haben."

"Leser wollen aber gerne, dass du eine Beziehung zu einem Autor hast, der in der großen Genealogie steht."

515 „Ich möchte keine Vorfahren haben und keine Nachkommen erzeugen."

„In welcher Familiengeschichte willst du aber verewigt werden, wenn du keine Nachkommen hast?"

520 Ein Traum, in dem einige Singvögel als Nationalspeise bestimmt werden. Es ist unklar, wer zu welcher Nation gehört, und es gilt als peinlich, danach zu fragen. Eine angebrannte Faust mit etwas Grünzeug auf meinem Teller. 525Die Speise wird hier schon vor der Geburt des Gastes bestellt. Der Teller singt seine Nationalhymne, kaltes Besteck klappert neben inm. Ein Kommentar springt aus dem Stammtisch:

530 „Arme Menschen essen alles, was sie finden. Aber wir essen nichts, was singt und fliegt."

Von der sonnigen Fensterseite behauptet jemand: „Vogelfleisch ist gesund."

535 Von der kritischen Kellerseite drängt die Meinung: „Wir zünden die Flagge der barbarischen Nation an, denn sie fressen immer noch wie im letzten Jahrhundert Fleisch. Im Notfall müsste man sie wirtschaftlich 540 erwürgen."

Mein Gesicht konnte in dieser Gesprächsrunde keine Stellung nehmen. Bald verschwanden die Sprachen der anderen. In meinem Mund blieb nur noch ein verkohlter 545 winziger Flügel übrig literatura europeia."

"Eu não quero ter um avô."

"Mas os leitores querem que você tenha uma relação com um autor que está na grande genealogia."

"Eu não quero ter ancestrais ou gerar descendentes."

"Mas em qual história de família você quer ser eternizada se não tiver descendentes?"

Um sonho no qual algumas aves canoras são definidas como prato nacional. Não é claro quem pertence a qual nação e é tido como constrangedor perguntar sobre isso. Um punho estorricado com um pouco de algo verde em meu prato. A refeição é pedida aqui já antes do nascimento do convidado. O prato canta seu hino nacional, talheres frios estalam perto dele. Um comentário salta da mesa dos habitués:

"Pessoas pobres comem tudo o que encontram. Mas nós não comemos nada que cante e voe."

Do lado ensolarado da janela alguém afirma: "Carne de ave é saudável."

Do lado crítico do porão a opinião insurge: "Nós queimamos a bandeira da nação bárbara, pois eles ainda devoram, como no século passado, carne. Em caso de emergência, deveríamos estrangulá-los economicamente."

Meu rosto não conseguiu tomar uma posição nessa roda de conversa. Logo desapareceram os idiomas dos outros. Na minha boca restou somente uma minúscula asa carbonizada. 


\section{Capítulo IV}

\section{Notas à tradução: comentários e apresentação de exemplos}

A proposta de tradução está baseada no estudo preliminar apresentado nos capítulos iniciais desta dissertação, de maneira que o texto traduzido visa a ilustrar os temas que permearam esse trabalho. Essa pesquisa permitiu identificar aspectos recuperados no texto traduzido, sendo que alguns deles são transpostos nestas notas para uma análise mais detida. Em linhas gerais, é possível dizer que, a partir da leitura da obra com vistas à sua tradução, o exercício tradutório consistiu em deixar transparecer o elemento estrangeiro no texto, de modo que os tópicos apresentados nesse capítulo buscam sistematizar esse exercício ressaltando alguns desses elementos, separados em determinadas categorias.

Este capítulo visa, então, a reunir as considerações dos capítulos 1 e 2 e demonstrar de que forma eles puderam servir de subsídio para o exercício de traduzir apresentado no capítulo 3. Para tanto, são expostos no presente capítulo alguns exemplos e comentários sobre a tradução de Latona e de Coronis exposta no capítulo anterior. Considerando, assim, as características da autora e de sua obra e, mais especificamente, de Ópio para Ovídio, a estratégia descrita na nota prévia (seção 3.1) será aprofundada através da reflexão sobre alguns resultados obtidos com o exercício tradutório.

Os comentários à tradução se referem, dentre outros elementos, à experiência estética com o estrangeiro e ao efeito de estranhamento causado pela aproximação com o texto de partida. Nesse sentido, a discussão sobre algumas escolhas consideradas representativas de minha atitude como tradutora e como pesquisadora ilustram os princípios que buscam permitir que o caráter estrangeiro do texto de partida transpareça no texto de chegada. Os exemplos estão divididos em quatro tópicos principais: (1) referências ao Livro do Travesseiro; (2) questões de léxico; (3) questões de morfologia e de sintaxe; (4) o vício, a saudade e o 
estrangeiro. Quanto às indicações de localização dos trechos retirados da tradução, as referências são organizadas da seguinte forma: (N2, 97, 48, 49) em que N2 se refere à narrativa 2 (Coronis), 97 à página desta dissertação, 48 à linha do texto de partida e 49 à linha do texto de chegada.

\section{Tópico 1. Referências ao Livro do Travesseiro}

O anúncio da intertextualidade na obra traduzida nesta dissertação se dá já a partir do título. Opium für Ovid: Ein Kopfkissenbuch von 22 Frauen (Ópio para Ovídio: um Livro do Travesseiro de 22 mulheres) indica ao leitor as referências literárias apresentadas no capítulo 2 deste trabalho, de modo que a menção ao Livro do Travesseiro pode se constituir como o primeiro contato com um caráter estranho ou desconhecido do texto. Sendo assim, são expostos a seguir alguns aspectos considerados na tradução para o português da palavra Kopfkissenbuch. Esses aspectos tratam principalmente das possibilidades de traduzir o título da obra de Sei Shônagon para o português, considerando a discussão apresentada abaixo sobre o filme The Pillow Book, de Peter Greenaway e sobre o título das duas traduções da obra literária para o português do Brasil.

Inicialmente, destacamos que esse filme de 1996, cujo título foi traduzido para o português como O Livro de Cabeceira é uma das referências ocidentais modernas a Sei Shônagon e, deste modo, poderia levar a uma aproximação com uma temática tida como possivelmente alheia. O filme faz inúmeras referências a Sei Shônagon, a começar também pelo próprio título The Pillow Book. Nesse sentido, faz-se importante notar que o filme de Peter Greenaway parece atribuir a Sei Shônagon palavras que constariam em seu Livro do Travesseiro. Consideramos pertinente ressaltar que, neste caso, tem-se um texto modificado, um fruto criativo do diretor, já que a "fidelidade" à obra literária não está necessariamente entre seus objetivos.

No entanto, embora a trama, as personagens e os diálogos de The Pillow Book sejam criação de Greenaway, o efeito que a personagem Sei Shônagon exerce sobre seus espectadores pode ser outro, conforme afirma CUNHA (2013:79), devido à 
"quantidade de pessoas, inclusive teóricos, que citam os trechos (do filme) como sendo de autoria da Sei Shônagon histórica.” Ainda segundo CUNHA:

(...) os diálogos do filme $O$ Livro de Cabeceira também foram reificados como sendo a palavra de Sei Shônagon, em um processo bem conhecido por quem tem que lidar com traduções de textos do Oriente (...): eles são apropriados, adaptados e reescritos a ponto de se tornarem irreconhecíveis, um produto da imaginação ocidental de como o Oriente deveria soar em tradução. (CUNHA 2013:80)

Ainda sobre a experiência audiovisual que faz reverberar essa obra literária japonesa no Ocidente, consideramos importante ressaltar, conforme CUNHA:

A transcrição da cultura do outro pode muito facilmente descambar para o exótico ou para uma espécie de ventriloquismo cujas implicações éticas são difíceis de compreender sem uma teoria da tradução e da tradução cultural, que dê conta de questões de autoria, identidade, voz, equivalência e erro. (...) A integração dos campos da tradução e da adaptação se faz necessária em especial em casos como O Livro de Cabeceira, em que tantos conceitos explosivos - nação, língua, gênero, origem - estão em jogo no momento de compreender a relação entre o papel e a película. (CUNHA 2013:90 e 91)

A crítica de Cunha contida na citação acima ressalta que a tradução do texto de Sei Shônagon, no caso do filme de Greenaway, representa como o Oriente, enquanto produto da imaginação ocidental, deveria soar. $O$ autor ressalta a importância da teoria da tradução e da tradução cultural, já que estão envolvidos os seguintes conceitos por ele citados: nação, língua, gênero e origem. Nesse sentido, acreditamos que a tradução do título do filme no Brasil por O Livro de Cabeceira corrobora para essa ideia de aclimatação da obra ao Ocidente.

Um dos elementos que caracterizam o Livro do Travesseiro de Sei Shônagon se refere ao processo de leitura e escrita na corte onde vivia a escritora. Esse processo era coletivo, de modo que o termo "livro de cabeceira", tal qual é utilizado atualmente, não remete às referências literárias relativas à cultura de sua época. Conforme WAKISAKA e CORDARO (2013):

Certamente a expressão [Makurano Sôshi] não tem o sentido atual de "livro de cabeceira", pois a leitura para as damas da corte imperial é atividade conjunta, simultânea e diuturna, pública, aliada à apreciação e crítica da caligrafia e das outras artes. (WAKISAKA e CORDARO 2013:9) 
Após essas considerações apresentadas sobre o filme The Pilow Book e a tradução de seu título no Brasil por O Livro de Cabeceira, ressalto que o livro Makurano Sôshi de Sei Shônagon foi traduzido para o português diretamente do japonês em duas ocasiões. Primeiramente, tem-se a tradução de Andrei dos Santos Cunha, publicada em 2008 e intitulada "O Livro de Travesseiro". A tradução mais recente, de 2013, realizada por Geny Wakisaka, Junko Ota, Lica Hashimoto, Luíza Yoshida e Madalena Cordaro foi intitulada O Livro do Travesseiro. As tradutoras explicam terem considerado uma das propostas de interpretação sobre o nome Makurano Sôshi, segundo a qual, Sei Shônagon teria feito uma associação com o termo makura, que significa travesseiro ou sela (Cf. WAKISAKA e CORDARO, 2013: 9).

Uma das acepções da palavra "cabeceira" também pode ser uma espécie de almofada para apoiar a cabeça, mas "livro de cabeceira" é um conceito mais frequentemente associado a uma leitura que se esteja fazendo e não propriamente a algo que se escreve. Nesse contexto, a tradução do título da obra estudada nesta pesquisa, leva à seguinte questão: traduzi-lo como $O$ Livro de Cabeceira levaria os leitores ainda mais em direção ao filme e à concepção atual que se tem de um livro de cabeceira e não à obra japonesa. Por fim, Tawada usou o termo Kopfkissenbuch para compor o título do livro e não Die Bettlektüre (A leitura de cama, em tradução literal) a propósito, título do referido filme de Greenaway em alemão, que tem nessa língua a conotação de "livro de cabeceira".

Assim, tendo em vista as questões levantadas sobre o filme e sobre o título do livro de Sei Shônagon, considero importante que a tradução para o português do título da obra de Yoko Tawada mantenha os traços da referência literária explícita por esta autora. O Livro do Travesseiro de 22 mulheres mantém um caráter de maior distanciamento para com a cultura ocidental, ao invés de buscar aclimatar essa referência a uma perspectiva mais próxima ao orientalismo criado pelo Ocidente. Essa escolha se coaduna, nesse contexto, com a estratégia de promover 0 estranhamento capaz de levar o leitor ao elemento estrangeiro do texto traduzido. 


\section{Tópico 2. Questões de léxico}

\subsection{Antropônimos}

Outra remissão ao intertexto, neste caso às Metamorfoses, de Ovídio, é expressa pelos nomes das personagens principais de Ópio para Ovídio. Esses e outros antropônimos presentes em Latona e Coronis constam na tabela abaixo:

\begin{tabular}{|l|l|l|}
\hline \multicolumn{1}{|c|}{ Localização } & Texto de Partida (TP) & Texto de Chegada (TC) \\
\hline $\begin{array}{l}\text { N1 possui 45 ocorrências do nome ao } \\
\text { longo deste texto. } \\
(\mathrm{N} 2,97,15,15)\end{array}$ & Latona & Latona \\
\hline$(\mathrm{N} 1,84,44,44)$ & Scylla & Cila \\
\hline (N1, 87, 110, 110) & Niobe & Níobe \\
\hline (N1, 87, 124, 124) & luno & Juno \\
\hline (N1, 93, 306, 306) & Shakti & Shakti \\
\hline (N1, 93, 307, 307) & Agni & Agni \\
\hline $\begin{array}{l}\text { N2 possui 70 ocorrências do nome ao } \\
\text { longo deste texto. }\end{array}$ & Coronis & Coronis \\
\hline (N2, 104, 243, 243) & Leda & Leda \\
\hline (N2, 111, 501, 501) & Nabokov & Nabokov \\
\hline (N2, 111, 507, 507) & Joyce & Joyce \\
\hline (N2, 111, 507, 507) & Proust & Musil \\
\hline (N2, 111, 508, 508) & Musil & \\
\hline
\end{tabular}

Latona e Coronis são as personagens que dão título às narrativas traduzidas e são também deusas das Metamorfoses, de Ovídio. Essas duas mulheres, assim como as outras vinte que dão título às suas respectivas histórias em Ópio para Ovídio, são personagens dessa obra do poeta latino. A versão dos antropônimos do texto em alemão é mais próxima do original em latim, mantida na tradução de Cândido Lusitano para o português (cf. PREDEBON, 2006). As versões Cila, Níobe e 
Juno aparecem na tradução para o português proposta por PREDEBON (2006) em sua revisão da tradução das Metamorfoses feita por Cândido Lusitano. Como pode ser verificado na tabela acima, com exceção desses três nomes, cuja manutenção da grafia como no texto de partida poderia gerar problemas na identificação dessas deusas, optamos por manter os demais antropônimos referentes às deusas sem alterações no texto em português.

Shakti e Agni, por sua vez, são deuses da narrativa Latona que não pertencem às Metamorfoses, de Ovídio. No livro de Tawada, o guru não consegue acender um cigarro com a força do pensamento e pede ajuda a um físico que produz esses dois deuses. Agni remete à palavra "fogo" em sânscrito (Cf. GoHN 2006:9), significado retomado no contexto que envolve essa personagem na narrativa. Shakti seria um princípio feminino ativo, força que se contrapõe e se complementa com Shiva, o princípio masculino, tido como passivo. Os dois antropônimos foram mantidos como no texto de partida.

Por fim, em Coronis, ao ser entrevistada por ocasião do recebimento de um prêmio literário, pedem a ela alguma declaração sobre um autor que está na "grande genealogia", pois "isso seria bom para o caderno especial sobre os gigantes da literatura europeia." (N2, 111, 509). Assim, os únicos antropônimos de Coronis que não fazem parte das Metamorfoses e que também foram mantidos como no texto de partida se referem aos escritores Nabokov, Joyce, Proust e Musil.

\subsection{Topônimos}

\begin{tabular}{|l|l|l|}
\hline \multicolumn{1}{|c|}{ Localização } & \multicolumn{1}{|c|}{ Texto de Partida (TP) } & Texto de Chegada (TC) \\
\hline$(\mathrm{N} 1,242,91,91)$ & China & China \\
\hline$(\mathrm{N} 1,412,96,96)$ & Tibet & Tibete \\
\hline$(\mathrm{N} 1,404,96,96)$ & München & Munique \\
\hline$(\mathrm{N} 1,404,96,96)$ & Stockholm & Estocolmo \\
\hline$(\mathrm{N} 1,404,96,96)$ & Asien & Ásia \\
\hline$(\mathrm{N} 1,84,61,61)$ & Glückstadt & Glückstadt \\
\hline
\end{tabular}




\begin{tabular}{|l|l|l|}
\hline$(\mathrm{N} 1,93,326,326)$ & Ottensen & Ottensen \\
\hline$(\mathrm{N} 1,96,409,409)$ & Peking & Pequim \\
\hline$(\mathrm{N} 2,97,48,49)$ & St. Pauli & St. Pauli \\
\hline
\end{tabular}

No caso dos topônimos Ottensen e Glückstadt, que se referem a um bairro de Hamburgo e a uma cidade de sua região metropolitana, respectivamente, a opção foi mantê-los como no texto de partida. Essa mesma atitude foi tomada em relação a St. Pauli, conhecido por ser um bairro boêmio de Hamburgo e a estação de metrô de mesmo nome, como é o caso no texto Coronis. Para os outros topônimos como Munique e Ásia, por exemplo, adotei a tradução brasileira consensual, pois apresentam uma forma consagrada em português, sendo que, nestes casos, considerei desnecessário gerar um estranhamento adicional.

\subsection{Nominalização}

É possível identificar na tabela abaixo a tentativa de manutenção da classe gramatical das palavras que, nestes exemplos, se deu pela substantivação dos verbos.

\begin{tabular}{|c|c|c|}
\hline Localização & Texto de Partida (TP) & Texto de Chegada (TC) \\
\hline$(\mathrm{N} 1,93,339,340)$ & $\begin{array}{l}\text { Aber wenn sie im Badezimmer } \\
\text { verschwand, hörte Latona kurz } \\
\text { darauf heftiges Flügelschlagen. }\end{array}$ & $\begin{array}{l}\text { Mas quando desaparecia no } \\
\text { banheiro, Latona ouvia pouco } \\
\text { depois um forte bater de asas. }\end{array}$ \\
\hline$(\mathrm{N} 2,105,285,285)$ & $\begin{array}{l}\text { Die Beschämung zieht den } \\
\text { Menschen nach unten }(. . .)\end{array}$ & $\begin{array}{l}\text { Envergonhar-se puxa as } \\
\text { pessoas para baixo (...) }\end{array}$ \\
\hline$(\mathrm{N} 2,109,429,429)$ & $\begin{array}{l}\text { Auf einem verblassten Foto sah } \\
\text { ich Coronis' Gesicht, rund und } \\
\text { glatt, ein spuckendes Gesicht, } \\
\text { ein Hinwerfen und kein } \\
\text { Hinschauen, ein Rennen und } \\
\text { Heulen ohne Berechnung. }\end{array}$ & $\begin{array}{l}\text { Numa foto empalidecida vi o } \\
\text { rosto de Coronis, redondo e } \\
\text { liso, um rosto cuspindo, } \\
\text { um atirar e não mirar, um } \\
\text { correr e berrar sem cálculo. }\end{array}$ \\
\hline
\end{tabular}


No primeiro exemplo exposto na tabela, o verbo schlagen (bater, golpear) foi nominalizado no texto em alemão dando origem ao substantivo Schlagen. O substantivo "golpe" seria Schlag, no plural, Schläge. Sendo assim, substituímos a opção das primeiras versões da tradução "fortes golpes de asas" por "um forte bater de asas", realizando, dessa forma, o mesmo processo percebido no texto de partida.

O exemplo seguinte se refere ao trecho de Coronis: Die Beschämung zieht den Menschen nach unten e foi traduzido como "Envergonhar-se puxa as pessoas para baixo". Inicialmente, havia optado por traduzir die Beschämung por "a vergonha". Mas essa alternativa não diferencia tal ocorrência da palavra Scham (vergonha), como no texto de partida. Além disso, Beschämung pode conter a ideia de uma espécie de processo não transposta em Scham (vergonha).

No último exemplo, tem-se uma sequência de substantivos no seguinte trecho: ein Hinwerfen und kein Hinschauen, ein Rennen und Heulen ohne Berechnung. Por serem formados a partir de verbos, os quatro primeiros substantivos utilizados para descrever a foto acabam por conferir certo movimento a ela. A escolha de "empalidecida" para traduzir verblassten também humaniza de algum modo a foto, que parece comportar essa ideia de não ser uma imagem estática ao mostrar o rosto de Coronis (N2, 109, 429): "um rosto cuspindo, um atirar e não mirar, um correr e berrar sem cálculo".

\subsection{Substantivos compostos}

Elencamos abaixo alguns exemplos resultantes do exercício de tentar recuperar 0 caráter dos substantivos compostos alemães na tradução para 0 português: 


\begin{tabular}{|l|l|l|}
\hline \multicolumn{1}{|c|}{ Localização } & \multicolumn{1}{|c|}{ Texto de Partida (TP) } & \multicolumn{1}{c|}{ Texto de Chegada (TC) } \\
\hline$(\mathrm{N} 1,84,64,65)$ & Arafat-Tuch & Lenço-Arafat \\
\hline$(\mathrm{N} 1,93,336,338)$ & blutrot & vermelho-sangue \\
\hline$(\mathrm{N} 1,95,397,397)$ & Unterleib & baixo-ventre \\
\hline (N2, 97, 1, 1) & Rauschzustand & estado-torpor \\
\hline (N2, 109, 425, 425) & Rauschmittel & substância-torpor \\
\hline $\begin{array}{l}\text { (N2, 97, 26, 25) } \\
\text { (N2, 97, 27, 27) } \\
\text { (N2, 97, 30, 29) } \\
\text { (N2, 98, 33, 32) }\end{array}$ & Farbe & tinta-cor \\
\hline $\begin{array}{l}\text { (N2, 101, 167, 167) } \\
\text { (N2, 102, 172, 172) }\end{array}$ & Scheinmücke & mosca-ilusão \\
\hline (N2, 101, 168, 167) & Scheinschatten & lábios-vergonha \\
\hline (N2, 102, 179, 178) & Nachtfalter & sombra-ilusão \\
\hline (N2, 104, 258, 258) & Vaterunser & mariposa-noite \\
\hline $\begin{array}{l}\text { (N2, 105, 280, 279) } \\
\text { (N2, 105, 287, 286) }\end{array}$ & Schamlippen & \\
\hline
\end{tabular}

Inicialmente, apresentamos algumas tentativas de recuperar os compostos Rauschzustand e Rauschmittel. O tema Rausch (torpor, embriaguês) é importante na obra e aparece também como substantivo simples em outros momentos do texto. Algumas das opções consideradas para traduzir o substantivo composto Rauschzustand foram: estado de torpor, estado ébrio e estado inebriado. Optamos por "estado-torpor" de modo a manter não somente a classe gramatical, mas também a repetição da palavra Rausch, presente em outros compostos como Rauschmittel.

Uma possibilidade de tradução para essa palavra Rauschmittel seria "substância entorpecente", mas essa alternativa pode apresentar um caráter vinculado a drogas ilegais, não necessariamente presente no texto de partida. 
Traduzir como "substância inebriante", por sua vez, também iria alterar a qualidade de substantivo presente na palavra Rausch. Por isso, conforme exposto na tabela acima, a opção final foi "substância-torpor".

Com relação a palavra Farbe foi feito o processo inverso, já que esse substantivo simples foi desmembrado em um composto na tradução. Isso foi feito pois em alguns trechos do texto em alemão a palavra Farbe tem o significado de "tinta" e, em outros, de "cor". Nesse sentido, o desdobramento da palavra pode proporcionar ao leitor a mesma gama de significados do original. Acredito ser pertinente essa ampliação de significado expressa pelo composto no texto traduzido como um exemplo de compensação, já que em muitos casos não considerei pertinente ou possível criar um substantivo composto em português para manter uma aproximação com o texto de partida.

No caso de "sombra-ilusão" e de "mosca-ilusão", as palavras em alemão Scheinschatten e Scheinmücke não se mostraram convencionais para falantes de alemão como língua materna. Portanto, mantive as opções que podem causar certo estranhamento também em português.

A palavra Nachtfalter, por sua vez, designa um tipo de mariposa e não parece causar o mesmo estranhamento. Porém, acreditamos que a escolha por esse inseto específico está inserida no contexto da "noite", em que a personagem Coronis lê à luz da noite $(\mathrm{N} 2,101,157)$. Assim, optamos por ressaltar o campo semântico constituído também pela presença da palavra Nacht (noite) no nome deste inseto. Dessa forma, "mariposa-noite" foi uma escolha baseada no propósito de não somente transpor a repetição do termo Nacht, mas também de deixar o elemento estrangeiro transparecer, permitindo que o leitor do texto tenha contato com a língua da tradução, uma língua de deslocamento entre o alemão e o português.

Quanto à palavra Schamlippen, traduzida como "lábios-vergonha", transcrevo o trecho em que aparece o termo para elucidar o campo semântico aqui presente:

TP [Texto de Partida] (N2, 105, 280): Coronis sucht nach ihren Schamlippen. "Schäm dich", sagte ihre Mutter manchmal zu ihr, wenn sie nach dem Baden nackt vor einem Spiegel stand. Man schämt sich nicht in Richtung des Himmels, sondern in Grund und Boden. Die Beschämung zieht den Menschen nach unten, Coronis sucht 
auf dem Boden nach ihren Schamlippen, sie sieht plötzlich eine Öffnung der Erde. Das sind große feuchte Lippen, die sich pausenlos bewegen, sie sind zum Sprechen da, zum Lispeln und zum Lallen. (grifos meus)

TC [Texto de Chegada] (N2, 105, 279): Coronis procura por seus lábios-vergonha. "Que vergonha você", dizia sua mãe às vezes a ela, quando, depois do banho, ficava nua diante do espelho. Não nos envergonhamos em direção ao céu, mas sim ao solo e ao chão. Envergonhar-se puxa as pessoas para baixo, Coronis procura no chão por seus lábios-vergonha, ela vê de repente uma fenda na terra. Estes são lábios grandes e úmidos, que se movimentam sem pausa, eles estão ali para falar com a língua presa e balbuciar. (grifos meus)

Uma das opções para traduzir Schamlippen seria "lábios pubianos"; porém, essa alternativa faz com que o texto de chegada não expresse a mesma cadeia de sentido presente no texto de partida. Esse elo é realizado, no trecho acima, principalmente pela repetição de Scham (vergonha) e de palavras derivadas ou relacionadas à mesma, como pode ser observado nos termos grifados. À medida que em português é possível relacionar "as vergonhas" aos órgãos sexuais humanos, acredito que essa expressão possa ser uma opção razoável para manter a proximidade com o texto de partida. Além disso, opto por manter a palavra "lábios" como forma de especificação do órgão sexual feminino e também para compor o campo semântico, já que, no texto, os lábios estão ali para falar.

É interessante notar, ainda, que a expressão sich in Grund und Boden schämen, denota a intensidade do sentimento de vergonha, no sentido de ficar profundamente envergonhado, "com a cara no chão". Tentei recuperar a imagem descrita em alemão que expõe a vergonha como sendo algo que empurra para o solo e para o chão, em contraponto ao céu. Essa expressão também possui ocorrências em contextos religiosos. ${ }^{74}$ Cabe ressaltar que 0 uso da palavra "vergonhas" no Brasil traz à tona certa moral religiosa, da qual era imbuída determinada perspectiva etnocêntrica sobre os hábitos e o comportamento dos "nativos", temática pertinente no caso de Ópio para Ovídio.

74 Cf. http://www.linguee.de/deutsch-

englisch/uebersetzung/sich+in+grund+und+boden+sch\%C3\%A4men.html 


\subsection{Itens lexicais de ancoragem cultural específica}

\begin{tabular}{|l|l|l|}
\hline \multicolumn{1}{|c|}{ Localização } & \multicolumn{1}{|c|}{ Texto de Partida (TP) } & \multicolumn{1}{c|}{ Texto de Chegada (TC) } \\
\hline (N1, 91, 260, 259) & $\begin{array}{l}\text { der große Wagen und der kleine } \\
\text { Wagen }\end{array}$ & $\begin{array}{l}\text { o grande veículo e o pequeno } \\
\text { veículo }\end{array}$ \\
\hline (N2, 97, 18,19) & Hochgewächs & planta de estatura \\
\hline (N2, 108, 403,403) & Kassenbrille & óculos baratos do seguro \\
\hline (N2, 112, 529,527) & Stammtisch & mesa dos habitués \\
\hline
\end{tabular}

No texto estudado de Yoko Tawada é possível notar marcas culturais de cunho ideológico vinculadas a sistemas políticos e crenças religiosas (Cf. AUBERT, 2006: 24-25), como no trecho de Latona transcrito abaixo:

TP (N1, 91, 252): Latona entdeckt in der Zeitung ein Foto und schneidet es aus. Es zeigt einen roten Stoff, der in einem Ofen brennt. Der Stoff kann ein Mönchsgewand sein oder eine Fahne. Neben der geöffneten Tür des Ofens sieht man das Markenzeichen des neuen chinesischen Autos „Der letzte Kaiser“. Latona erinnert sich daran, dass zwei große Strömungen im Buddhismus gibt, die als der große Wagen und der kleine Wagen bezeichnet werden.

TC (N1, 91, 252): Latona encontra uma foto no jornal e a recorta. Ela mostra um tecido vermelho que arde em um forno. O tecido pode ser o hábito de um monge ou uma bandeira. Junto à porta aberta do forno, vê-se o logotipo do novo carro chinês "O último Imperador". Latona se lembra que há duas correntes no budismo chamadas de o grande veículo e o pequeno veículo.

Conforme apresentado na seção 1.3, o livro Das Nackte Auge (2004) de Yoko Tawada é expressivo em relação às referências cinematográficas e cada capítulo leva como título o nome de um filme. No caso de Latona, a referência a Der letzte Kaiser parece promover a associação com o filme de Bernardo Bertolucci $O$ último Imperador (1987). Numa das cenas desse filme, PuYi, o último imperador chinês, pergunta a seu tutor escocês se George Washington tem um carro e diz que gostaria de ter um. Na Cidade Proibida chinesa, à qual só tinham acesso o 
Imperador e pessoas ligadas à corte, não entram carros. Na passagem transcrita acima, é possível observar como o elo semântico do texto se constrói a partir de um elemento irônico, que relaciona um automóvel chinês a duas correntes do Budismo.

Essa temática não apresenta, em princípio, alto grau de proximidade nem com a cultura meta da tradução, nem com a cultura de partida. Além disso, um outro ponto a ser ressaltado refere-se ao fato de que as correntes budistas expressas em alemão como "der große Wagen und der kleine Wagen" podem se referir também às constelações Ursa Maior e Ursa Menor. O contexto, porém, aponta para o Budismo e apresenta um paralelo com o carro chinês citado no contexto acima. Optamos, portanto, por traduzir os termos como "o grande veículo e o pequeno veículo".

No que se refere a Kassenbrille, por sua vez, tem-se uma composição da palavra Kasse ("caixa", em referência ao seguro-saúde), qualificando os óculos (Brille). Segundo consta no dicionário Duden, o uso desse termo é informal e frequentemente pejorativo. Trata-se de um certo tipo de óculos de modelo simples, pago pelo seguro ${ }^{75}$, sendo que algumas opções para recuperar essa ideia em português seriam: óculos baratos; óculos do plano / do seguro-saúde; ou, por fim, óculos baratos do seguro. Optei por essa última expansão, para manter a ideia de que são pagos pelo plano e, ao mesmo tempo, a nuance pejorativa dos "óculos baratos."

Um outro item lexical de ancoragem cultural específica refere-se ao termo Hochgewächs. A palavra compõe-se do atributo hoch (alto) e do substantivo Gewächs (planta). Ao ser perguntada sobre o que é uma árvore, a narradora do texto Coronis, permeado pelo entorpecimento dos sentidos, opta por defini-la como "Hochgewächs", que não significa simplesmente uma planta grande, alta, mas se refere, mais especificamente, a uma designação de origem de certo tipo de vinho. Apesar de não ter sido possível recuperar no texto traduzido essa ligação direta a um tipo de vinho, procuramos com a tradução por "planta de estatura" remeter à ideia metafórica de uma espécie de árvore de "categoria elevada".

75 Cf. Duden: Kassenbrille_Gebrauch: umgangssprachlich, oft abwertend. Brille einfacher Ausführung, die von der Krankenkasse bezahlt wird . 
Por fim, ressalto alguns aspectos do último item lexical da tabela, Stammtisch, que consta no seguinte trecho ao final de Coronis:

TP (N2, 112, 525): Die Speise wird hier schon vor der Geburt des Gastes bestellt. Der Teller singt seine Nationalhymne, kaltes Besteck klappert neben ihm. Ein Kommentar springt aus dem Stammtisch:,Arme Menschen essen alles, was sie finden. Aber wir essen nichts, was singt und fliegt."

TC (N2, 112, 525): A refeição é pedida aqui já antes do nascimento do convidado. O prato canta seu hino nacional, talheres frios estalam perto dele. Um comentário salta da mesa dos habitués: "Pessoas pobres comem tudo o que encontram. Mas nós não comemos nada que cante e voe."

Stammtisch pode ser considerada uma mesa em um restaurante ou bar em que se encontram regularmente um círculo de Stammgäste (frequentadores habituais) e que, na maioria das vezes, está reservada para esses convidados. Ressaltamos, ainda, que stammen tem sentido de descender, ser natural ou provir de algum lugar. Stamm pode significar, ainda, tronco, estirpe e, na morfologia, se refere à raiz ou ao radical. Esses significados são importantes para a estrutura semântica do texto, de modo que, tendo em vista esse campo semântico, a palavra Stammtisch poderia ser traduzida como: mesa cativa; dos de casa; dos frequentadores habituais, habitués ou assíduos. Além disso, outra alternativa seria deixar Stammtisch em alemão e inserir uma nota de rodapé.

A alternativa escolhida foi "mesa dos habitués", pois acredito que ela seja capaz de transmitir certa ideia de diferenciação entre "nós", da Stammtisch, e os demais convidados que não apresentam esse status, fator que implica a ideia de pertencimento a um grupo por seu distanciamento em relação aos outros, aos de fora dele. 


\subsection{Alternativas para se traduzir Sprache}

A importância da língua na obra de Yoko Tawada se dá não somente por ser um tema caro à autora, mas também por se constituir em constante objeto de reflexão em seus textos. Essa reflexão se volta ao alemão falado e escrito por ela como uma língua estrangeira, de modo que a estrangeiridade de seu instrumento de trabalho acaba por se materializar em seus textos. Essas questões foram apresentadas na seção 1.3 desta dissertação, onde também foi exposta a percepção da escritora quanto à materialidade da língua. Em Coronis, no excerto abaixo, o torpor pode ser materialmente sentido nas frases dessa escritora:

\footnotetext{
Eu era uma amante da literatura de Coronis.

"Eu admiro sua literatura há dez anos. Suas frases têm algo de entorpecedor."

Eu tinha me referido com "entorpecedor" na verdade a uma substância-torpor concreta, que pode ser materialmente sentida nas frases de Coronis. Mas eu não quis dizer isto assim tão diretamente. (N2, 109, 420)
}

A percepção de uma dimensão física da linguagem aparece, ainda, em momentos nos quais Yoko Tawada remete à língua, parte do corpo (Zunge), como no título do livro Überseezungen. Conforme exposto na seção 1.3, esse título aglutina a sobreposição de Übersee (além-mar), Zungen (línguas) e Übersetzung (tradução). A palavra gerada com a sobreposição nos remete, ainda, aos verbos übersetzen, com a sílaba tônica "se" (traduzir) e übersetzen, verbo separável (atravessar de uma margem à outra).

Embora essa pluralidade de sentidos seja, por vezes, construída pela autora, é importante notar que no caso do texto Coronis, há ocorrências da palavra Sprache, cuja tradução por "língua" poderia gerar uma dubiedade não presente no texto de partida. Assim, consideramos também as opções "linguagem" e "idioma" para identificar a escolha da autora pela palavra Sprache em contextos nos quais "língua" pudesse ser interpretada equivocadamente como a parte do corpo.

Em Coronis, a palavra Sprache aparece grifada nas ocorrências elencadas abaixo - não há nenhuma ocorrência em Latona. 


\begin{tabular}{|c|c|c|}
\hline Localização & Texto de Partida (TP) & Texto de Chegada (TC) \\
\hline (N2,97, 35, 34) & $\begin{array}{l}\text { Es ist die Karte mit der } \\
\text { Überschrift "Sprachen in } \\
\text { Ostmitteleuropa } \\
\text { Südosteuropa" }\end{array}$ & $\begin{array}{l}\text { É o mapa com o título } \\
\text { "Línguas no Leste da Europa } \\
\text { Central e no Sul do Leste } \\
\text { Europeu" }\end{array}$ \\
\hline$(\mathrm{N} 2,98,59,59)$ & $\begin{array}{l}\text { Das immer lauter werdende } \\
\text { Gespräch findet in einer } \\
\text { ausländischen Sprache } \\
\text { statt keiner wird sie } \\
\text { verstehen. Zufällig ist es } \\
\text { aber die Sprache, die } \\
\text { Coronis' Mutter gesprochen } \\
\text { hat. }\end{array}$ & $\begin{array}{l}\text { A conversa aumentando } \\
\text { cada vez mais de volume } \\
\text { acontece numa língua outra, } \\
\text { ninguém a compreenderá. } \\
\text { Mas, por coincidência, é a } \\
\text { língua que a mãe de } \\
\text { Coronis falava. }\end{array}$ \\
\hline$(\mathrm{N} 2,99,84,84)$ & $\begin{array}{l}\text { Kann man an Coronis' } \\
\text { Gesicht sehen, dass sie die } \\
\text { Sprache einer Diktatur } \\
\text { versteht? }\end{array}$ & $\begin{array}{l}\text { É possível ver no rosto de } \\
\text { Coronis que ela entende a } \\
\text { língua de uma ditadura? }\end{array}$ \\
\hline$(\mathrm{N} 2,99,91,91)$ & $\begin{array}{l}\text { Könnte trotzdem jemand } \\
\text { sehen, dass die Sprache } \\
\text { Coronis' Nerven trifft? }\end{array}$ & $\begin{array}{l}\text { Apesar disso, alguém } \\
\text { conseguiria ver que a língua } \\
\text { atinge os nervos de Coronis? }\end{array}$ \\
\hline$(\mathrm{N} 2,100,110,110)$ & $\begin{array}{l}\text { „Aber Sie verstehen die } \\
\text { Sprache, die die drei Männer } \\
\text { gesprochen haben." }\end{array}$ & $\begin{array}{l}\text { "Mas a senhora entende a } \\
\text { língua que falavam os três } \\
\text { homens." }\end{array}$ \\
\hline$(\mathrm{N} 2,106,311,309)$ & $\begin{array}{l}\text { Sie braucht keine andere } \\
\text { Person, sondern eine } \\
\text { Sprache. }\end{array}$ & $\begin{array}{l}\text { Ela não precisa de outra } \\
\text { pessoa, mas de uma } \\
\text { linguagem. }\end{array}$ \\
\hline (N2, 111,490,490) & $\begin{array}{l}\text { Hinter dem Zeitungspapier } \\
\text { ärgert sie sich über } \\
\text { Diskriminierungen jeder } \\
\text { Sorte, Verfall der } \frac{\text { Sprache, }}{\text { der }} \\
\text { Beschneidung } \\
\text { Kulturgelder, aber ihr Körper } \\
\text { wird nie auf einer Straße } \\
\text { ausgesetzt, auf der rohe } \\
\text { Stimmen herumfliegen. }\end{array}$ & $\begin{array}{l}\text { Atrás do papel de jornal ela } \\
\text { se enfurece com } \\
\text { discriminações de todo tipo, } \\
\text { decadência da língua, o } \\
\text { corte de verbas para a } \\
\text { cultura, mas seu corpo } \\
\text { nunca será abandonado em } \\
\text { uma rua, pela qual voam } \\
\text { vozes cruas. }\end{array}$ \\
\hline$(\mathrm{N} 2,112,543,543)$ & $\begin{array}{l}\text { Bald verschwanden die } \\
\text { Sprachen der anderen. }\end{array}$ & $\begin{array}{l}\text { Logo desapareceram os } \\
\text { idiomas dos outros. }\end{array}$ \\
\hline
\end{tabular}


Como pode ser observado na tabela acima, a tradução escolhida para a maioria das ocorrências de Sprache foi "língua". Destacamos, abaixo, os exemplos em que se considerou problemática essa alternativa para o texto de chegada. No excerto a seguir, o contexto não deixaria claro em português que não se trata da parte do corpo, por isso, a opção escolhida foi "linguagem" para evitar uma possível dubiedade não presente no texto de partida.

TP. (N2, 106, 311): Eine krankhafte Sucht nach Menschen zwingt Coronis, sich auf eine schutzlose Person zu stürzen, um ihr zu schaden. Die sexuelle Lust hingegen hat für sie etwas Autistisches. Sie braucht keine andere Person, sondern eine Sprache. Coronis erlebt den fleischlichen Höhepunkt beim Schreiben.

TC. (N2, 106, 309): Um vício doentio por pessoas força Coronis a se lançar sobre um indivíduo indefeso para feri-lo. O desejo sexual, por outro lado, tem para ela algo de autista. Ela não precisa de outra pessoa, mas de uma linguagem. Coronis experimenta o clímax carnal ao escrever.

No trecho transcrito a seguir, também é possível identificar que a tradução de Sprache por "língua" poderia ser entendida pela parte do corpo devido ao contexto. Nesse sentido, levamos em conta que no ambiente de um sonho envolvendo questões de ordem nacional, "idioma" seria pertinente por apresentar a dimensão de uma língua própria de um povo, de uma nação.

TP. (N2, 112, 543): Mein Gesicht konnte in dieser Gesprächsrunde keine Stellung nehmen. Bald verschwanden die Sprachen der anderen. In meinem Mund blieb nur noch ein verkohlter winziger Flügel übrig.

TC. (N2, 112, 543): Meu rosto não conseguiu tomar uma posição nessa roda de conversa. Logo desapareceram os idiomas dos outros. Na minha boca restou somente uma minúscula asa carbonizada. 


\section{Tópico 3. Questões de morfologia e de sintaxe}

\subsection{Pronomes pessoais}

Conforme apresentado no capítulo 2, Tawada ressalta a questão da identidade bem definida do "eu", segundo a perspectiva ocidental, como um indivíduo praticamente imutável e fechado em si mesmo. Ainda nesse mesmo capítulo, foi exposto que, conforme GEISEL (2001), não há no japonês um pronome específico para "eu". Nesse sentido, sua presença repetida em alguns momentos de Ópio para Ovídio parece enfatizar essa busca por uma identidade do "eu" ocidental em contraponto ao "Outro". Sendo assim, buscamos retomar em determinados pontos do texto traduzido a repetição desse pronome pessoal, conforme apresentado na tabela abaixo:

\begin{tabular}{|c|c|c|}
\hline Localização & Texto de Partida (TP) & Texto de Chegada (TC) \\
\hline$(\mathrm{N} 1,84,1,1)$ & $\begin{array}{l}\text { Ich sehe eine Flammensäule aus } \\
\text { einem Hügel ragen. Schon wieder } \\
\text { ein neues Atomkraftwerk? Ich } \\
\text { hatte oft ähnliche Plakate } \\
\text { gesehen. }\end{array}$ & $\begin{array}{l}\text { Eu vejo uma coluna de labaredas } \\
\text { erguer-se de uma colina. De novo } \\
\text { uma nova usina atômica? Eu tinha } \\
\text { visto com frequência cartazes } \\
\text { parecidos. }\end{array}$ \\
\hline$(\mathrm{N} 2,106,334,334)$ & $\begin{array}{l}\text { „Wenn du deine Bilder malen willst, } \\
\text { geh doch malen. Keiner verbietet } \\
\text { dir das." } \\
\text { "Ich kann nicht. Ich muss unser } \\
\text { Brot verdienen." } \\
\text { "Aber du kannst doch abends und } \\
\text { am Wochenende malen." } \\
\text { "Du verstehst mich nicht. Ich kann } \\
\text { nicht malen, wenn ich Geld } \\
\text { verdienen muss." }\end{array}$ & $\begin{array}{l}\text { "Se você quer pintar seus quadros, } \\
\text { vá pintar então. Ninguém lhe } \\
\text { proíbe". } \\
\text { "Eu não posso. Eu preciso ganhar } \\
\text { nosso pão." } \\
\text { "Mas você pode sim pintar à noite } \\
\text { e nos fins de semana." } \\
\text { "Você não me entende. Eu não } \\
\text { posso pintar se eu preciso ganhar } \\
\text { dinheiro." }\end{array}$ \\
\hline$(\mathrm{N} 2,109,420,420)$ & $\begin{array}{l}\text { „Ich war eine Liebhaberin von } \\
\text { Coronis' Literatur. } \\
\text { „Ich bewundere ihre Literatur seit } \\
\text { zehn Jahren. Ihre Sätze haben } \\
\text { etwas Rauschhaftes." } \\
\text { Ich hatte mit "rauschhaft" } \\
\text { eigentlich ein konkretes } \\
\text { Rauschmittel gemeint, das in } \\
\text { Coronis' Sätzen materiell zu } \\
\text { spüren ist. Aber so direkt wollte } \\
\text { ich das nicht sagen. }\end{array}$ & $\begin{array}{l}\text { "Eu era uma amante da literatura } \\
\text { de Coronis. } \\
\text { "Eu admiro sua literatura há dez } \\
\text { anos. Suas frases têm algo de } \\
\text { entorpecedor." } \\
\text { Eu tinha me referido com } \\
\text { "entorpecedor" na verdade a uma } \\
\text { substância-torpor concreta, que } \\
\text { pode ser materialmente sentida } \\
\text { nas frases de Coronis. Mas eu não } \\
\text { quis dizer isto assim tão } \\
\text { diretamente. }\end{array}$ \\
\hline
\end{tabular}


A presença dos pronomes pessoais no texto traduzido pode ter, por vezes, um caráter diferente daquele presente no texto em alemão, já que nessa língua a supressão dos pronomes não seria gramaticalmente aceita. Nesse ponto, retomo a proposta deste trabalho que consiste em fazer com que a língua alemã transpareça no texto em português, causando certo estranhamento e revelando algumas escolhas da autora, conforme descrito mais adiante. Assim, mesmo quando os pronomes pessoais podem ser suprimidos no texto em português, isso não foi feito em alguns trechos, como nos transcritos no quadro acima.

Além da recorrência do "eu", nota-se, na segunda transcrição da tabela, a repetição do pronome pessoal "você". Ressaltamos o trecho em que Coronis e seu marido conversam, prevalecendo uma contraposição entre "você" e "eu" (N2, 106, 334,334). Esses pronomes pessoais iniciam uma sequência de frases, nas quais o "eu", dito pelo marido, é aquele que precisa trabalhar para ganhar o pão em contraponto a sua mulher, que acha ser possível fazer arte e sobreviver. O encontro entre "você" e "eu" se dá, na fala do marido, somente pelo possessivo "nosso", através do qual ele compartilha o pão e a culpa.

Por fim, cabe ressaltar, conforme exposto no capítulo 2, que as personagens de Ópio para Ovídio apresentam uma identidade diluída nos fragmentos contados em suas narrativas. Elas não têm praticamente nada de definitivas e seu "eu" parece resistir à própria abstração para designações profissionais, familiares ou nacionais. Dessa forma, o processo de repetição desse pronome em determinados trechos pode ter o efeito de enfatizar ironicamente sua presença constante, mas um tanto vazia de certezas.

\subsection{Particípio I}

Com relação ao Particípio I do alemão (Partizip I), tem-se uma estrutura formada a partir de verbos, cuja função é frequentemente de atributo ou pode, ainda, designar alguma ação que está sendo feita em determinado momento. Buscamos não desmembrar as construções em uma oração relativa, de modo que as opções de tradução para o português envolvem formas como o gerúndio, o particípio e adjetivos. Os exemplos referentes a esse fenômeno aparecem grifados na tabela abaixo: 


\begin{tabular}{|c|c|c|}
\hline Localização & Texto de Partida (TP) & Texto de Chegada (TC) \\
\hline$(\mathrm{N} 1,84,11,1)$ & $\begin{array}{l}\text { Der Hügel stellt den rasierten Kopf } \\
\text { eines meditierenden Menschen dar. }\end{array}$ & $\begin{array}{l}\text { A colina representa a cabeça } \\
\text { raspada de um ser meditante. }\end{array}$ \\
\hline$(\mathrm{N} 1,89,200,201)$ & $\begin{array}{l}\text { Er ist anscheinend für Menschen } \\
\text { gedacht, die zwanzig oder dreißig } \\
\text { Jahre jünger sind als sie und einen } \\
\text { leeren Raum vor Augen haben, den } \\
\text { sie mit frisch riechendem Holzleben } \\
\text { einrichten können. }\end{array}$ & $\begin{array}{l}\text { Ele parece ser pensado para } \\
\text { pessoas vinte ou trinta anos mais } \\
\text { jovens do que ela e que têm } \\
\text { diante dos olhos um cômodo } \\
\text { vazio que podem mobiliar com } \\
\text { vida de madeira cheirando a } \\
\text { fresco. }\end{array}$ \\
\hline$(\mathrm{N} 2,97,20,20)$ & $\begin{array}{l}\text { Ein Baum ist ein Hochgewächs mit } \\
\text { festem Stamm, aus dem Äste } \\
\text { wachsen, die sich in laub- oder } \\
\text { nadeltragende Zweige teilen. }\end{array}$ & $\begin{array}{l}\text { Uma árvore é uma planta de } \\
\text { estatura com tronco rígido, do } \\
\text { qual crescem galhos, que se } \\
\text { separam em ramos carregados } \\
\text { com folhagens ou agulhas. }\end{array}$ \\
\hline$(\mathrm{N} 2,98,33,32)$ & $\begin{array}{l}\text { Bald vermischen sie sich } \\
\text { miteinander und erzeugen neue, } \\
\text { schwindelerregende Farben. }\end{array}$ & $\begin{array}{l}\text { Logo se misturam umas às } \\
\text { outras e produzem novas, } \\
\text { vertiginosas tintas-cores }\end{array}$ \\
\hline$(\mathrm{N} 2,98,57,58)$ & $\begin{array}{l}\text { Das immer lauter werdende } \\
\text { Gespräch (...) }\end{array}$ & $\begin{array}{l}\text { A conversa aumentando cada } \\
\text { vez mais de volume }(. . .)\end{array}$ \\
\hline$(\mathrm{N} 2,101,143,141)$ & $\begin{array}{l}\text { Von irgendeiner Uhrzeit, dem } \\
\text { Hauptbahnhof und den schlafenden } \\
\text { Kindern zu Hause oder so etwas } \\
\text { haben sie gesprochen. }\end{array}$ & $\begin{array}{l}\text { Sobre algum horário, a estação } \\
\text { principal e as crianças dormindo } \\
\text { em casa ou algo assim eles } \\
\text { falaram. }\end{array}$ \\
\hline
\end{tabular}

\subsection{A ordem dos elementos na oração: sintaxe e posição dos atributos}

\section{- A Sintaxe}

Os trechos expostos na tabela abaixo são exemplos de versões em que buscamos a aproximação com a sintaxe alemã. Esse exercício de aproximação se deu principalmente em direção a trechos do texto de partida nos quais foram percebidas formulações passíveis de estranhamento já em alemão ou, ainda, onde parecia haver uma proposta de ênfase em determinados elementos. 


\begin{tabular}{|c|c|c|}
\hline Localização & Texto de Partida (TP) & Texto de Chegada (TC) \\
\hline$(\mathrm{N} 1,84,10,10)$ & $\begin{array}{l}\text { Der Hügel stellt den rasierten } \\
\text { Kopf eines meditierenden } \\
\text { Menschen dar. Aus seinem Kopf } \\
\text { spuckt er Feuergedanken. }\end{array}$ & $\begin{array}{l}\text { A colina representa a cabeça } \\
\text { raspada de um ser meditante. De } \\
\text { sua cabeça ele cospe } \\
\text { pensamentos de fogo. }\end{array}$ \\
\hline (N1, 93, 313, 313) & $\begin{array}{l}\text { Sie meinen, es gibt keinen } \\
\text { Körper? } \\
\text { Körper gibt es viele in dieser } \\
\text { Welt. }\end{array}$ & $\begin{array}{l}\text { Você acha que não existem } \\
\text { corpos? } \\
\text { Corpos existem muitos neste } \\
\text { mundo. }\end{array}$ \\
\hline$(\mathrm{N} 2,100,126,125)$ & $\begin{array}{l}\text { Von Coronis bekommt ein Bote } \\
\text { der staatlichen Macht keine } \\
\text { einzige Reaktion, keine Spucke, } \\
\text { keine Tränen, keine zitternde } \\
\text { Stimme, kein Schimpfwort. }\end{array}$ & $\begin{array}{l}\text { De Coronis não recebe um } \\
\text { mensageiro do poder estatal } \\
\text { nem uma única reação, nenhum } \\
\text { cuspe, nenhuma lágrima, } \\
\text { nenhuma voz trêmula, nenhum } \\
\text { palavrão. }\end{array}$ \\
\hline$(\mathrm{N} 2,101,141,140)$ & $\begin{array}{l}\text { Von irgendeiner Uhrzeit, dem } \\
\text { Hauptbahnhof und den } \\
\text { schlafenden Kindern zu Hause } \\
\text { oder so etwas haben sie } \\
\text { gesprochen. }\end{array}$ & $\begin{array}{l}\text { Sobre algum horário, a estação } \\
\text { principal e as crianças dormindo } \\
\text { em casa ou algo assim eles } \\
\text { falaram. }\end{array}$ \\
\hline$(\mathrm{N} 2,104,235,235)$ & $\begin{array}{l}\text { Coronis bekommt eine Karte, } \\
\text { darauf steht ein schwarz } \\
\text { eingerahmter Text, das Datum } \\
\text { und der Ort einer Beerdigung. }\end{array}$ & $\begin{array}{l}\text { Coronis recebe um cartão, ali } \\
\text { está emoldurado em preto um } \\
\text { texto, a data e o local de um } \\
\text { enterro. }\end{array}$ \\
\hline$(\mathrm{N} 2,107,365,366)$ & $\begin{array}{l}\text { Für ihre Fehler trägt die } \\
\text { berühmte Diktatur die Schuld, sie } \\
\text { kann nichts dafür. }\end{array}$ & $\begin{array}{l}\text { Pelos seus erros carrega a } \\
\text { culpa a famosa ditadura, ela não } \\
\text { pode fazer nada. }\end{array}$ \\
\hline$(\mathrm{N} 2,112,535,535)$ & $\begin{array}{l}\text { Von der sonnigen Fensterseite } \\
\text { behauptet jemand: „Vogelfleisch } \\
\text { ist gesund." } \\
\text { Von der kritischen Kellerseite } \\
\text { drängt die Meinung: „Wir zünden } \\
\text { die Flagge der barbarischen } \\
\text { Nation an (...) }\end{array}$ & $\begin{array}{l}\text { Do lado ensolarado da janela } \\
\text { alguém afirma: "Carne de ave é } \\
\text { saudável." } \\
\text { Do lado crítico do porão a } \\
\text { opinião insurge: "Nós queimamos } \\
\text { a bandeira da nação bárbara (...) }\end{array}$ \\
\hline
\end{tabular}

Inicialmente, destacamos o seguinte exemplo do quadro acima:

TP. (N1, 93, 313): Sie meinen, es gibt keinen Körper?“

„Körper gibt es viele in dieser Welt." 
TC. (N1, 93, 313): "Você acha que não existem corpos?"

"Corpos existem muitos neste mundo."

Esse trecho ilustra como a manutenção da ordem dos elementos da oração propicia o eco gerado pela repetição da palavra "Körper". Cabe pontuar que na primeira ocorrência de Körper a palavra está no singular e na segunda, no plural. A palavra alemã tem a mesma ortografia em ambos os casos, por isso optamos pela tradução "corpos" nas duas frases, para manter o efeito de repetição do texto de partida.

Na maioria dos demais exemplos expostos na tabela, é possível identificar que o complemento dativo antecede o nominativo nas orações. Esse tipo sequência pode causar certo estranhamento também na língua de partida, além de enfatizar os elementos que iniciam a frase. Isso ocorre no exemplo transcrito abaixo, em que a contraposição entre o comportamento de Coronis e o das meninas locais, criticadas anteriormente por essa personagem, acaba sendo ressaltada:

TP. (N2, 100, 126): Von Coronis bekommt ein Bote der staatlichen Macht keine einzige Reaktion, keine Spucke, keine Tränen, keine zitternde Stimme, kein Schimpfwort.

TC. (N2, 100,125): De Coronis não recebe um mensageiro do poder estatal nem uma única reação, nenhum cuspe, nenhuma lágrima, nenhuma voz trêmula, nenhum palavrão.

No trecho abaixo, em que as opiniões partem de lados distintos do restaurante, a divergência das ideias é ressaltada com as diferentes posições dos falantes que iniciam as frases, o que confere também certo movimento à cena descrita:

TP. (N2, 112, 535): Von der sonnigen Fensterseite behauptet jemand: „Vogelfleisch ist gesund." Von der kritischen Kellerseite drängt die Meinung: „Wir zünden die 
Flagge der barbarischen Nation an, denn sie fressen immer noch wie im letzten Jahrhundert Fleisch. Im Notfall müsste man sie wirtschaftlich erwürgen."

TC. (N2, 112, 535): Do lado ensolarado da janela alguém afirma: "Carne de ave é saudável." Do lado crítico do porão a opinião insurge: "Nós queimamos a bandeira da nação bárbara, pois eles ainda devoram, como no século passado, carne."

Destaco, por fim, outro caso de "inversão", em que o complemento dativo precede o sujeito, sendo possível identificar a opção de iniciar a frase com os fragmentos da memória de Coronis. Ao ser interrogada pelos policiais, a personagem vai se lembrando aos poucos do suposto conteúdo da conversa que ouvira no metrô, de modo que sua fala apresenta um caráter fragmentário:

TP. (N2, 101, 141): Von irgendeiner Uhrzeit, dem Hauptbahnhof und den schlafenden Kindern zu Hause oder so etwas haben sie gesprochen.

TC. (N2, 101, 140): Sobre algum horário, a estação principal e as crianças dormindo em casa ou algo assim eles falaram.

De modo geral, nas versões iniciais da tradução ${ }^{76}$, anteriores aos exemplos expostos na tabela, as soluções encontradas talvez fossem consideradas mais "naturais" em português. Nessas versões, pode ser observada uma tentativa de trazer os elementos para uma sequência mais aclimatada, por assim dizer. Após ampliarmos as reflexões a respeito da estratégia de tradução e da visão da própria Yoko Tawada sobre o texto traduzido, passamos a realizar o exercício de aproximação às passagens do texto alemão, de modo que foi feita a tentativa de transpor determinadas escolhas sintáticas presentes no texto de partida para o texto de chegada.

\footnotetext{
${ }^{76}$ As versões intermediárias da tradução podem ser acessadas pelo link: https://www.dropbox.com/home/Alice\%20do\%20Vale
} 


\section{- Posição dos atributos}

É possível identificar, nos exemplos expostos abaixo, um exercício de anteposição dos atributos no texto em português, como ocorre necessariamente na língua alemã.

\begin{tabular}{|l|l|l|}
\hline \multicolumn{1}{|c|}{ Localização } & \multicolumn{1}{|c|}{ Texto de Partida (TP) } & \multicolumn{1}{c|}{ Texto de Chegada (TC) } \\
\hline$(\mathrm{N} 1,84,5,6)$ & eines neuen Atomkraftwerkes & de uma nova usina atômica \\
\hline$(\mathrm{N} 1,84,22,20)$ & ein neuer Körper & um novo corpo \\
\hline$(\mathrm{N} 1,92,273,273)$ & sieben fette Raubvögel & sete gordas aves de rapina \\
\hline$(\mathrm{N} 1,88,160,158)$ & eine neue Möbelkultur & uma nova cultura de móveis \\
\hline (N1, 89,193,193) & die teuren Hormonspritzen & as caras injeções de hormônios \\
\hline (N1,91,259,260) & $\begin{array}{l}\text { der große Wagen und der kleine } \\
\text { Wagen }\end{array}$ & $\begin{array}{l}\text { o grande veículo } \text { veículo } \\
\text { veno }\end{array}$ \\
\hline (N1, 92, 289, 291) & fette Wasserrosen & gordas flores de lótus \\
\hline (N1, 93, 320, 320) & ein gutes Buch & um bom livro \\
\hline (N1, 93, 335, 340) & heftiges Flügelschlagen & forte bater de asas \\
\hline (N1, 94, 351, 351) & ein feines Gehör & um bom ouvido \\
\hline (N1, 96, 429, 429) & neue Haare & novos cabelos \\
\hline (N2, 97, 6, 6) & meines alten Füllers & minha velha caneta tinteiro \\
\hline (N2, 98, 33,32) & neue, schwindelerregende & novas, vertiginosas tintas-cores \\
\hline (N2, 102, 194,194) & gute Augen & bons olhos \\
\hline (N2, 107, 348,347) & bösen Geister & maus espíritos \\
\hline (N2, 107, 366,367) & die berühmte Diktatur & eltricas tintas-cores dos mitos \\
\hline
\end{tabular}

Nos exemplos expostos na tabela acima, é possível identificar que esse exercício de anteposição dos adjetivos se concentrou nos casos em que a língua portuguesa parece comportar melhor essa opção. Sendo assim, não foi realizada a anteposição em casos como "vermelho vestido" ou "branco elefante", por exemplo, 
que forçam demais a língua de chegada a ponto de gerar um grau considerado excessivo e desnecessário de estranhamento. Também não foram antepostos os adjetivos nos casos em que o registro do texto pudesse ser alterado, conferindo-lhe não somente um tom divergente do texto de partida, mas também uma outra significância. Isso aconteceria, por exemplo, se o trecho eine geläufige Rhetorik des erwachsenen Kapitalismus (cf. N2,107,364) fosse traduzido por "corrente retórica do capitalismo adulto", ao invés da opção escolhida: "retórica corrente do capitalismo adulto."

Em casos como os elencados no quadro acima, os adjetivos antepostos podem trazer à tona uma camada de significação do texto de partida que se perderia caso fossem pospostos aos substantivos no texto traduzido. Esses exemplos buscam ilustrar o exercício de manter uma proximidade formal e de sentido com o texto de partida como em: "forte bater de asas", "maus espíritos" ou "o grande veículo e o pequeno veículo" - estas últimas servindo de designação às correntes budistas, conforme exposto anteriormente no tópico 2.5 sobre os itens lexicais de ancoragem cultural específica.

No excerto "minha velha caneta tinteiro" há uma relação de afeto com esse objeto que pode ser recuperada no texto de chegada pela anteposição do atributo. O mesmo acontece com "um bom livro", que está entre as coisas que, além de uma banheira, segundo Latona, pertencem a muitas pessoas. A qualidade do livro cobiçado parece ser destacada, assim, na opção escolhida, mais do que o seria com a construção "um livro bom".

Por fim, faz-se importante frisar que a anteposição dos atributos expostos na tabela acima pode gerar certo grau de estranhamento em português, mas parece aceitável segundo a noção da tradução como um texto estrangeiro e estrangeirizante, que possa trazer aspectos linguísticos presentes na língua de partida e, por vezes, reproduzir no leitor da cultura de chegada a experiência do desconforto ao se confrontar com algo que não lhe é familiar. 


\section{Tópico 4. O vício, a saudade e o estrangeiro}

Estão agrupados neste último tópico aspectos temáticos recorrentes no livro traduzido que desempenham um papel importante na constituição do campo semântico da obra. Eles agem como um fio tênue que permite relacionar as vinte e duas mulheres e, mais especificamente, devido ao recorte feito neste trabalho, Latona e Coronis. Sendo assim, faz-se importante evidenciar a opção de tratar as questões de tradução voltadas a esses temas em separado das questões sobre o léxico, apresentadas no tópico 2 deste capítulo. Essa escolha se deu pelo fato desses aspectos estarem intimamente relacionados à temática mesma do livro e às reflexões feitas a partir do exercício tradutório e da pesquisa como um todo.

Esses temas estão vinculados ao vício, à saudade e às perspectivas sobre o estrangeiro, o Outro em contraponto à visão do observador, o alheio a determinada nação da qual não se origina. Assim, juntamente com o anseio por uma droga, por amor, por uma pessoa, pelo passado ou pelo vir a ser, são expostas no Livro do Travesseiro de Yoko Tawada perspectivas comumente estranhas a um certo tipo de visão etnocêntrica.

Considerando esses aspectos, o presente tópico está dividido em dois subitens. No primeiro deles, trato do campo semântico construído pela repetição da palavra Sucht, como em Sucht e Sehnsucht (vício e saudade, respectivamente). O segundo subitem, por sua vez, consiste na apresentação de exemplos relacionados ao termo fremd, recuperado em palavras que remetem à migração, ao (não) pertencimento e ao estranhamento em relação ao Outro.

\subsection{O vício e a saudade}

Como apresentado no capítulo 2, a referência a um estado entorpecido permeia Ópio para Ovídio desde o título do livro. Em Latona, o vício (Sucht) se refere não somente às substâncias que entorpecem, mas também aos sentimentos, como um vício em amor e a ânsia por um ciúme, por exemplo. Nesse sentido, se constitui um campo semântico através da repetição de Sucht como substantivo simples ou, 
como pode ser observado na tabela abaixo, na ocorrência de palavras com possível relação (ortográfica e/ou semântica) com esse termo.

\begin{tabular}{|l|l|l|}
\hline \multicolumn{1}{|c|}{ Localização } & \multicolumn{1}{|c|}{ Texto de Partida (TP) } & \multicolumn{1}{c|}{ Texto de Chegada (TC) } \\
\hline $\begin{array}{l}(\mathrm{N} 1,87,117,117) \\
(\mathrm{N} 1,87,121,121) \\
(\mathrm{N} 1,87,122,121) \\
(\mathrm{N} 1,87,126,124)\end{array}$ & Eifersucht & ciúme \\
\hline $\begin{array}{l}\mathrm{N} 1,87,120,120) \\
(\mathrm{N} 2,105,292,293)\end{array}$ & Sehnsucht & anseios \\
\hline $\begin{array}{l}\mathrm{N} 1,87,121,121) \\
(\mathrm{N} 2,105,292,292)\end{array}$ & saudade \\
(N2, 106, 306, 305) & vício \\
\hline (N1, 87, 118, 118) & eifersüchtig & tem ciúme \\
\hline (N1, 87, 119, 118) & eifersüchtig & ciumenta \\
\hline (N1, 90, 218, 219) & sehnsüchtig & saudosa \\
\hline (N1, 88, 162, 161) & liebessüchtig & viciado em amor \\
\hline (N2, 110, 441, 441) & angriffssüchtigen & viciadas em ataque \\
\hline
\end{tabular}

Como pode ser identificado nos exemplos elencados acima, persistiu a dificuldade de encontrar na língua de chegada uma mesma palavra que possa estar contida nas ideias de "vício", "saudade" e "ciúme", como em Sucht, Sehnsucht e Eifersucht, respectivamente. Algumas alternativas às escolhas apresentadas na tabela estariam vinculadas à expansão dessas ideias como em "vício em anseio" para Sehnsucht ou à criação de palavras como "viciúme" para Eifersucht, e "viciumento" para eifersüchtig. Descartei essas possibilidades, pois iriam causar um estranhamento excessivo em comparação ao efeito obtido com o texto de partida.

No que se refere às alternativas encontradas, ressalto, inicialmente, o caso do substantivo Sucht. Considerado de forma isolada, Sucht pode indicar uma mania por alguém ou alguma coisa, uma avidez, um anseio ou um vício. Essas ideias compõem o campo semântico desta obra permeada pelo ópio e por um estado de 
torpor, em que é latente a busca por satisfazer uma vontade irresistível, uma ânsia. O "vício" em Coronis aparece nos dois excertos transcritos abaixo:

TP. (N2, 105, 292): Bei Coronis haben Sucht und Sehnsucht nie aufgehört.

TC.(N2, 105, 292): Em Coronis nunca cessaram o vício e a saudade.

TP. (N2, 106, 306): Eine krankhafte Sucht nach Menschen zwingt Coronis, sich auf eine schutzlose Person zu stürzen, um ihr zu schaden.

TC. (N2,106, 305): Um vício doentio por pessoas força Coronis a se lançar sobre um indivíduo indefeso para feri-lo.

O vício em Latona, por sua vez, se propaga pelo ciúme, pela saudade e por outras acepções expostas na tabela acima. Transcrevemos, a seguir, um trecho no qual aparecem grifados os termos cujas traduções serão, posteriormente, fundamentadas.

TP. (N1, 87, 116): „Jemand reißt mir die Haare aus, während ich schlafe. Aus Eifersucht. Ich weiß, dass jemand auf mich eifersüchtig ist".

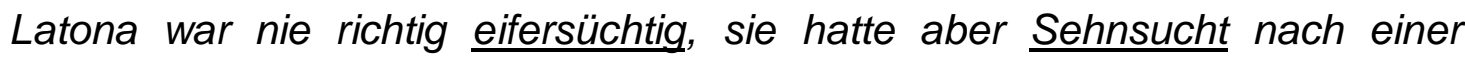

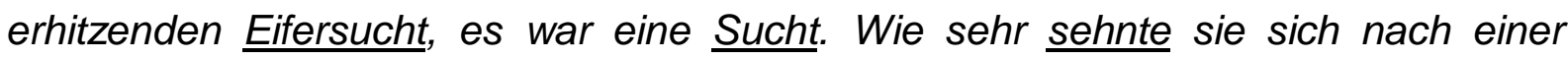
Eifersucht! Im Wochenendseminar über den tibetanischen Buddhismus lernte sie eine Frau namens luno kennen, diese Frau beherrschte die Kunst der Eifersucht. (grifos meus)

TC. (N1, 87,116): "Alguém arranca meus cabelos enquanto durmo. Por ciúme. Eu sei que alguém tem ciúme de mim."

Latona nunca foi realmente ciumenta, ela tinha anseios por um ciúme ardoroso, era um vício. Como ela ansiava por um ciúme! No seminário de fim de semana sobre Budismo Tibetano, ela conheceu uma mulher de nome Juno, essa mulher dominava a arte do ciúme. (grifos meus) 
Inicialmente, podem ser observadas na passagem acima duas traduções distintas para o atributo eifersüchtig (ciumenta ou que tem ciúme). Consideramos necessário alterar a categoria gramatical dessa palavra em sua primeira ocorrência e optamos, nesse caso, por "ter ciúme" ao invés do atributo, devido às possibilidades de construção sintática da frase em português.

No que se refere a Sehnsucht, por sua vez, temos uma palavra ligada à acepção de saudade ou de uma saudade do futuro, do vir a ser, podendo ser entendida, dessa forma, como um anseio ou uma ânsia. Como pode ser observado no quadro no início deste tópico (4), Sehnsucht foi traduzida de duas formas distintas. Em Coronis, como exposto nos excertos acima, optou-se pela tradução como "saudade". Já na ocorrência em Latona, essa opção iria alterar a significação presente no texto de partida, pois a ideia de "saudade de um ciúme ardoroso" não corresponderia a uma personagem que nunca foi realmente ciumenta. Por essa razão, a alternativa escolhida foi "ela tinha anseios por um ciúme ardoroso" (cf. N1, 87,117).

Por fim, pode-se dizer que as alternativas escolhidas não recuperam de modo tão contundente, como no texto de partida, a repetição de Sucht. Contudo, há na tradução uma ideia de repetição obtida com a aliteração do som /s/. Ele está contido em todas as palavras em português, conforme os termos grifados na passagem acima e as demais palavras elencadas na tabela. Assim, prevalece a atitude da tradutora de considerar as manifestações do texto de partida e tentar recuperar de algum modo suas marcas no processo de produção do texto traduzido.

\subsection{O estrangeiro: perspectivas}

Conforme exposto nos capítulos anteriores, o deslocamento é uma constante na obra de Yoko Tawada. Esse deslocamento envolve não somente as viagens e os processos de migração, mas também a alteração de perspectivas e até mesmo a própria ideia de tradução. $\mathrm{O}$ quadro abaixo concentra as acepções relacionadas à concepção de movimento, mudança e pertencimento, nos quais a contraposição entre $o$ eu e o Outro se constitui por perspectivas que tendem a uma desnaturalização do olhar. 


\begin{tabular}{|c|c|c|}
\hline Localização & Texto de Partida (TP) & Texto de Chegada (TC) \\
\hline (N1, 84, 24,23) & unangemeldet & não se anunciam \\
\hline $\begin{array}{l}(\mathrm{N} 2,98,41,41) \\
(\mathrm{N} 2,99,95,95) \\
(\mathrm{N} 2,100,113,113) \\
(\mathrm{N} 2,106,321,321) \\
(\mathrm{N} 2,106,322,322) \\
(\mathrm{N} 2,110,464,464)\end{array}$ & $\begin{array}{l}\text { Einheimische Frauen } \\
\text { Einheimischen Frauen } \\
\text { die einheimischen Mädchen } \\
\text { Einheimischen } \\
\text { Einheimische } \\
\text { einheimischen Mann }\end{array}$ & $\begin{array}{l}\text { mulheres nativas } \\
\text { mulheres nativas } \\
\text { das jovens nativas } \\
\text { nativo } \\
\text { nativo } \\
\text { homem nativo }\end{array}$ \\
\hline$(\mathrm{N} 2,98,58,59)$ & ausländische Sprache & língua outra \\
\hline$(\mathrm{N} 2,99,66,66)$ & Landsleute & conterrâneos \\
\hline$(\mathrm{N} 2,99,70,70)$ & Heimatgenossen & compatriotas \\
\hline$(\mathrm{N} 2,100,131,130)$ & Abgemeldete & sem-registro \\
\hline (N2, 101, 137, 136 & fremden Leuten & estranhos \\
\hline$(\mathrm{N} 2,104,240,240)$ & übersiedelte & mudou-se \\
\hline $\begin{array}{l}\text { (N2,104,261,261) } \\
(\mathrm{N} 2,106,320,320)\end{array}$ & Emigration & emigração \\
\hline$(\mathrm{N} 2,104,245,245)$ & wanderte & vagava \\
\hline (N2,107, 344, 344) & Außenstehender & alguém de fora \\
\hline (N2, 110, 452, 452) & fremdländisch & alheio ao lugar \\
\hline
\end{tabular}

Ressalto, inicialmente, as palavras unangemeldet e Abgemeldete, que aparecem nos trechos transcritos abaixo:

TP. (N1, 84, 24): Wie viele Körper muss man mit sich schleppen? Einige der Körper sind unangemeldet. Sie sind zwar erotisch, aber für keinen sexuellen Akt nutzbar. Vielleicht sind sie illegal, aber sie können nicht bestraft werden, denn sie sind unsichtbar. 
TC. (N1, 84, 23): Quantos corpos a gente tem de carregar consigo? Alguns dos corpos não se anunciam. Eles são, sim, eróticos, mas inúteis para qualquer ato sexual. Talvez sejam ilegais, mas não podem ser punidos, pois são invisíveis.

TP. (N2,100,125): Eine emotionale Reaktion verbindet Menschen miteinander. Von Coronis bekommt ein Bote der staatlichen Macht keine einzige Reaktion, keine Spucke, keine Tränen, keine zitternde Stimme, kein Schimpfwort. Coronis bleibt unfassbar und ungreifbar wie eine Abgemeldete.

TC. (N2,100,124): Uma reação emocional liga as pessoas umas às outras. De Coronis não recebe um mensageiro do poder estatal nem uma única reação, nenhum cuspe, nenhuma lágrima, nenhuma voz trêmula, nenhum palavrão. Coronis permanece intocável e inatingível como uma sem-registro.

$\mathrm{O}$ texto traz indícios de que ambas as palavras - unangemeldet $\mathrm{e}$ Abgemeldete - podem se referir ao registro que um cidadão residente na Alemanha deve possuir ao se cadastrar como morador de determinada cidade. Em Latona, a menção a uma possível ilegalidade no texto faz com que seja explícita a dimensão da falta de registros desses "corpos". Sendo assim, optei por traduzir unangemeldet como "não se anunciam", para retomar também essa significação mais abrangente, do termo alemão. "Sem-registro", por sua vez, foi a solução adotada para Abgemeldete, presente em Coronis, no excerto transcrito acima, em que está presente a ideia de alguém que não existe perante o Estado.

Ainda no que se refere a Coronis, como apresentado no capítulo 2, a personagem emigrou e, no país em que reside, é constantemente perguntada pela origem e observada pelas pessoas, como se houvesse algo de estranho nela, algo de diferente dos demais e que despertasse a atenção alheia. Essa situação é descrita no trecho abaixo, onde está a palavra fremdländisch, cuja tradução será discutida posteriormente:

TP. (N2, 110, 447): Coronis wird oft von Passanten betrachtet. Die Augen der Dorfbewohner starren sie an. Die Augen der Großstädter starren sie ebenso an: in 
Straßenbahnen, in Restaurants, in Kaufhäusern. Das ist insofern rätselhaft, als es bei ihr nichts Auffälliges gibt, was man als fremdländisch empfinden könnte.

TC. (N2, 110, 447): Coronis é frequentemente observada por passantes. Os olhos dos moradores do vilarejo fitavam-na. Os olhos dos da cidade grande fitavam-na da mesma forma: nos bondes, nos restaurantes, nas lojas de departamento. Isso é tão mais enigmático, pois nela não há nada que chame atenção, algo que se possa sentir como alheio ao lugar.

Fremdländisch pode qualificar aquele que se origina de um outro país ou cultura. A palavra pode apresentar, ainda, a acepção de "exótico" ou "estranho". Fremd traz, por si só, a conotação de estrangeiro e fremdländisch parece ressaltar a perspectiva do não pertencimento a determinado país. Por isso, optei por desdobrar a palavra em "alheio ao lugar", considerando a acepção de fremd como alheio.

Ainda nesse campo semântico, é possível notar no trecho abaixo que a palavra ausländisch aparece no contexto de uma língua estrangeira, que, em princípio, ninguém no vagão do metrô poderia compreender:

TP. (N2, 98,57): Das immer lauter werdende Gespräch findet in einer ausländischen Sprache statt, keiner wird sie verstehen. Zufällig ist es aber die Sprache, die Coronis' Mutter gesprochen hat.

TC. (N2, 98, 57): A conversa aumentando cada vez mais de volume acontece numa língua outra, ninguém a compreenderá. Mas, por coincidência, é a língua que a mãe de Coronis falava.

A questão que se levanta quanto à tradução de ausländische Sprache seria a diferença em relação a Fremdsprache, esta última traduzida comumente como "língua estrangeira". Com a finalidade de expressar uma nuance mais marcada de ausländisch, a alternativa escolhida foi traduzir a expressão como "língua outra". A opção "outra língua" foi considerada, no entanto, essa colocação poderia sugerir que os falantes passaram a se comunicar entre si em uma língua diferente daquela em que começaram a conversa. 
Além disso, é importante notar que traduzir ausländische Sprache como uma "língua outra" permite contemplar uma gama de significados voltados à estrangeiridade, que ao longo do texto se desdobra em palavras como "estranho", "alheio" e, por fim, "outra". Ainda no que se refere à passagem acima, outro aspecto a ser destacado é o fato de que essa língua estrangeira não é estranha para Coronis, pois é a língua de sua mãe. Mas tampouco é nomeada como sua língua materna, de modo que o texto constrói uma constante variação no campo das perspectivas alternantes.

Essa alternância está presente também na descrição do convívio de Coronis com seu marido. Sob a perspectiva dele, ela é a "estranha" em questão, no sentido de estar alheia à lógica do capitalismo moderno:

TP. (N2, 107, 339): „Du verstehst mich nicht. Ich kann nicht malen, wenn ich Geld verdienen muss." Coronis bekommt plötzlich Angst vor dem Wort Geld, denn es wird so ausgesprochen, als würde eine geheimnisvolle Logik dahinterstecken, die ein Außenstehender nicht verstehen kann.

TC. (N2, 107, 339): "Você não me entende. Eu não posso pintar, se preciso ganhar dinheiro." Coronis ficou de repente com medo da palavra dinheiro, pois é falada de tal modo, como se escondesse uma lógica misteriosa por trás de si que alguém de fora não consegue compreender.

Coronis é escritora e provém de um país comunista e, em princípio, estaria à margem da lógica capitalista exposta pelo marido. A palavra Außenstehender, grifada no excerto acima, pode ser entendida como alguém não pertencente a determinado grupo ou sociedade ou a uma certa lógica estabelecida por eles. Algumas das opções consideradas para o texto de chegada foram: "não iniciado" ou "estranho" (cf. Wahrig) e, ainda, outsider. Neste último caso, a palavra poderia recuperar a ideia de um indivíduo que não pertence ao grupo dos que entendem a lógica do dinheiro.

No entanto, levando-se em conta que a palavra mais específica para outsider em alemão seria Außenseiter, não escolhida pela autora, optou-se por desmembrar Außenstehender em "alguém de fora". Essa alternativa permite contemplar o 
significado de que Coronis sente não conhecer todos os valores dominantes na sociedade em que vive. No texto traduzido pode haver, ainda, a interpretação de que a personagem vem de fora daquele país, mas como esse é o caso de Coronis, não considerei essa dubiedade uma perda para a tradução.

Por fim, citamos um exemplo relacionado ao deslocamento do olhar também no texto Coronis, obtido através da exposição das perspectivas da personagem título. Segundo Coronis, os cidadãos locais do país para o qual se mudou são considerados os "outros" e o modo como ela os nomeia explicita um tipo de visão com a qual o marido, um cidadão local, se surpreende e se incomoda. Abaixo está transcrito um dos momentos da narrativa em que essa visão é explicitada:

TP. (N2, 106, 320): Nach der Emigration heiratete Coronis einen Einheimischen. Schon mehrmals sagte er, sie solle nicht das Wort „Einheimische" benutzen, es höre sich an, als spräche eine Ethnologin von den Wilden.

TC. (N2, 106, 320): Depois de sua emigração Coronis se casou com um nativo. Já várias vezes ele disse que ela não deveria usar a palavra "nativo", isso soava como se uma etnóloga falasse dos selvagens.

Em Coronis, a palavra Einheimische aparece algumas vezes antes do trecho transcrito, com outras declinações, conforme pode ser visto na tabela apresentada anteriormente. Ela causa certo estranhamento nas primeiras ocorrências, até que o marido de Coronis compartilha, por assim dizer, desse efeito causado pelo uso da palavra. A conotação de Einheimische, segundo a perspectiva do marido de Coronis, está vinculada aos selvagens, uma categoria da qual ele naturalmente não faz parte.

Diante disso, algumas possibilidades de tradução como "local" ou "natural do lugar" não explicitariam o tom irônico presente no texto de origem. Já a alternativa escolhida, "nativo", pode ressaltar de modo contundente, assim como Einheimische, o distanciamento entre o eu e o Outro e permite lançar um olhar para a inversão de perspectivas que a língua pode construir. Com a escolha dessa palavra é desvelada uma lógica inversa a certa visão já naturalizada, seja pelo colonizador, seja por sociedades que exercem algum tipo de dominação ou suposta supremacia, de 
modo que se veem, eles mesmos, colocados na posição de estranhos e alheios perante esses outros olhos.

O efeito de estranhamento possivelmente gerado com esse exercício de deslocamento do olhar é algo que se coaduna com o traduzir entendido como releitura e reescritura em prol de uma transposição transformadora, conforme a visão de Yoko Tawada exposta nos capítulos anteriores. Se a autora de Ópio para Ovídio escreve em uma língua estrangeira (Fremdsprache) e sobre o estrangeiro (Fremde), não seria coerente apagarmos esse caráter do texto traduzido. Nesse sentido, esperamos que os exemplos expostos neste capítulo possam ter explicitado o caminho do deslocamento em direção ao fremd. 


\section{Considerações Finais}

Os processos migratórios motivados por guerras, miséria, perseguição política ou por livre escolha de quem migra são uma constante e influenciam praticamente todas as esferas da vida em sociedade. No espectro das atitudes possíveis em relação a esses processos há dois polos opostos: receber o estrangeiro ou apartá-lo. Por um lado, o medo e as posições xenófobas erguem muros e ganha força o polo da repulsão. Por outro lado, não é possível desconsiderar as tentativas de receber o estrangeiro e de permear pouco a pouco as fronteiras entre o próprio e o alheio.

A literatura produzida em alemão como língua estrangeira pode ser um dos poros capazes de permitir um contato transformador. Escritores e escritoras das mais diversas origens linguístico-culturais fazem da língua alemã seu instrumento de trabalho, atravessam um dos limites mais representativos do que ainda pode restar do caráter nacional e se apropriam dele criativamente.

Deparar-se com os textos desses autores é ter contato com a diferença, com uma atitude que se contrapõe à assimilação servil ou à integração, no sentido da total absorção de si por determinada cultura. Pelo contrário, ao explicitarem um caráter cultural diverso e uma personalidade em constante transformação, esses escritores apontam para a constatação de que o Outro não é necessariamente uma ameaça a ser homogeneizada segundo determinados critérios etnocêntricos.

Outras formas de representação artística talvez circulem de modo mais "naturalizado" pelas fronteiras entre os países, já que não sofrem a delimitação linguística, um dos pontos fortes do caráter de uma nação, como dito anteriormente. Justamente por isso, a literatura feita em uma língua estrangeira pode explicitar a possibilidade latente de uma sociedade não só conviver com a diferença, mas acima de tudo, fazer dela uma característica fecunda.

As delimitações estabelecidas a esses escritores se dão, inicialmente, pelas designações atribuídas à sua literatura, tais como as apresentadas na seção $\mathbf{1 . 1}$ deste trabalho: literatura intercultural, de migrantes, do estrangeiro, das minorias, de fora, multicultural, não somente alemã, de homens e mulheres migrantes, do 
fremd (estranho, alheio e estrangeiro), entre outras. Tais denominações parecem evocar um caráter que não necessariamente privilegia as características da obra, mas simplesmente ressalta a origem ou o não pertencimento nacional dos autores e autoras. Nesse sentido, faz-se importante ressaltar que, mais do que perseguir uma denominação que parecesse adequada para sua literatura, buscamos reunir, nesta dissertação, alguns agentes vinculados ao subsistema literário alemão composto por esses escritores, conforme expusemos na seção 1.2.

Com o intuito de tentarmos expandir o âmbito das categorias, acabamos por nos deparar com uma espécie de paradoxo: se, por um lado, essas categorias implicam certo apartamento de uma literatura "alemã de fato", por outro lado, elas propiciam encontros e permitem que os escritores por elas englobados recebam uma série de incentivos para o exercício de sua carreira literária. Além disso, a partir dessa pesquisa, foi possível perceber que esses autores e autoras das mais variadas origens linguístico-culturais não estão necessariamente à margem do sistema literário alemão.

Como expusemos já no primeiro capítulo desta dissertação, Yoko Tawada considera positiva a possibilidade de estar em contato com escritores tão diversos por ocasião de eventos específicos para determinadas categorias, nas quais também ela é englobada. No entanto, a autora destaca que as denominações conferidas a eles não são capazes de caracterizar de fato a sua literatura.

Seu arcabouço cultural, assim como tantos outros elementos formadores da identidade do artista, têm implicações em sua escrita, contudo, na dualidade gerada pela possibilidade de reunir esses autores e, ao mesmo, apartá-los dos demais, talvez o equilíbrio esteja no ato de focarmos na análise de sua obra, colocando a mesma em primeiro plano, antes de sua origem nacional. É certo que o elemento que os unifica é a apropriação que fazem de uma língua estrangeira como instrumento de seu trabalho criativo e, no caso de Yoko Tawada, ela não somente escreve em uma língua estrangeira, mas também sobre ela. Neste contexto, tal como apresentado na seção 1.3, a escritora não parece querer apagar o caráter de estrangeiridade, o fremd por assim dizer, de sua escrita, mas, pelo contrário, opta pela atitude de explicitá-lo. 
Conforme expusemos no capítulo 2, em Ópio para Ovídio o foco narrativo não está necessariamente no discurso metalinguístico, mas sim intertextual. As obras Metamorfoses, de Ovídio, e o Livro do Travesseiro, de Sei Shônagon, se reconstituem nesse livro de Yoko Tawada através de elementos temáticos e estruturais das narrativas. As vinte e duas mulheres deste Livro do Travesseiro transitam entre a tradição literária ocidental e a oriental em um processo de releitura e reescrita da memória intertextual no presente. A tradução, por sua vez, pode ser lida como parte do processo de diálogo criado por Tawada com os dois textos milenares, podendo se constituir, assim, em um dos elementos dessa transposição transformadora.

As mulheres, personagens e autoras de si mesmas, promovem um deslocamento constante do olhar, na medida em que costuram uma trama de perspectivas ao avesso das naturalidades. Elas circulam por St. Pauli, pela China ou pelo céu e se metamorfoseiam no decorrer dos caminhos. Suas personalidades apresentam uma constituição fluida, como que dissolvida em água, substância tão cara a Yoko Tawada.

O distanciamento em relação à língua alemã é propício para esse processo de desnaturalização do olhar, uma das características preponderantes da escrita de Yoko Tawada. Escrever em uma língua estrangeira requer a lida com a diferença por princípio, numa demonstração das possibilidades de contato criativo com o Outro. A estrangeiridade pode e deve transparecer e não há razão para tentar apagar as marcas de sua estranheza. Isso seria a integração em seu sentido mais reducionista, aquela de mão única, em que a complexidade do considerado estranho é reduzida a determinados aspectos de outra cultura.

Segundo essa mesma perspectiva, a versão da tradução exposta no capítulo 3 deste trabalho não poderia apagar seu caráter próprio em função de um texto completamente aclimatado à cultura de chegada. Partindo desse pressuposto, foi feito um exercício contínuo de desvelar aspectos da língua alemã, que é, no âmbito de Ópio para Ovídio, estrangeira já no texto de partida. Assim, no decorrer do processo tradutório, foi sendo incorporada uma lida provocadora com a linguagem, principalmente no que se refere às categorias expostas nas notas à tradução e nos comentários que constituem o capítulo 4. 
Por fim, sublinhamos a tradução como um espaço de provocação que se justifica no interior deste trabalho acadêmico, onde $o$ ato de traduzir e a pesquisa se explicam mutuamente, constituindo um todo capaz de contemplar algumas das nuances do fremd marcadas no rosto do texto traduzido. Desse modo, perseguimos uma tradução que, ao adquirir uma língua própria, possa servir como elemento transformador, tornando visível ao olhar deslocado a face profícua da permeabilidade das fronteiras. 


\section{Referências Bibliográficas}

\section{CORPUS}

TAWADA, Yoko. Opium für Ovid : Ein Kopfkissenbuch von 22 Frauen. Tübingen: Konkursbuch Verlag Claudia Gehrke. 3 ed., 2011.

\section{OUTRAS REFERÊNCIAS LITERÁRIAS}

OVÍDIO. Metamorfoses. In: Predebon, Aristóteles. Edição do manuscrito e estudo das Metamorfoses de Ovídio traduzidas por Francisco José Freire. Tese de Mestrado. Orientador: Prof.Dr. João Angelo Oliva. Universidade de São Paulo, 2006. SHÔNAGON, Sei. O Livro do Travesseiro. Tradução de Geny Wakisaka, Junko Ota, Lica Hashimoto, Luíza Yoshida, Madalena Cordaro. Editora 34: São Paulo, 2013. TAWADA, Yoko. Talisman. Tübingen: Konkursbuch Verlag Claudia Gehrke, 2008 (6.Auflage).

Überseezungen. Tübingen: Konkursbuch Verlag Claudia Gehrke, 2010 (3.Auflage).

Das nackte Auge. Tübingen: Konkursbuch Verlag Claudia Gehrke, 2004 Capítulo 1 em:

http://www.konkursbuch.com/html/netfr2004/yokoAugeKapitel\%201.htm.

Última consulta em 26/06/2016

TAWADA, Yoko. Opium pour Ovide: Notes de chevet sur vingt-deux femmes. Tradução de Bernard Banoun. Verdier: Lagrasse, 2002. 


\section{DEMAIS REFERÊNCIAS BIBLIOGRÁFICAS}

AMODEO Immacolata. Bettrofenheit und Rhizom, Literatur und Literaturwissenschaft. In: Migrationsliteratur: Eine neue deutsche Literatur? HeinrichBöll-Stiftung: Berlin,2009. Disponível em formato Pdf salvo em 20.07.2013:

http://www.migration boell.de/downloads/integration/DOSSIER_Migrationsliteratur.pdf ASSMANN, Aleida. Einführung in die Kulturwissenschaft:Grundbegriffe, Themen und Fragestellungen. Erich Schmidt: Berlin, 2011.

AUBERT. F. Indagações acerca dos marcadores culturais na tradução. In: Revista de Estudos Orientais, Vol.5.2006, p. 23-36.

AZENHA, J. Linguística textual e tradução: redefinindo o conceito de marca cultural. In: Tradterm, 12, 2006, p.13-33.

AZENHA, J. Transferência cultural em tradução: contextualização, desdobramentos, desafios. In: Tradterm, 16, 2010, p. 37-66.

BANDIA, Paul e MILTON, John (eds.) - Agents of Translation. Amsterdam, Philadelphia: John Benjamins Publishing Company, 2008.

BAKER, Mona e SALDANHA, Gabriela - Routledge Encyclopedia of Translation Studies. 2nd edition. London, New York: Routledge, 2008.

BERMAN, Antoine. A prova do estrangeiro. Cultura e tradução na Alemanha romântica: Herder, Goethe, Schlegel, Novalis, Humboldt, Schleiermacher, Hölderlin. Tradução de Maria Emília Pereira Chanut. Bauru: Edusc, 2002.

BLUME, Rosvitha Friesen. Traços migratórios e tradução cultural na obra ensaística de Herta Müller e de Yoko Tawada. Itinerários, Araraquara, n. 38, jan./jun. 2014. p.59-72.

BLIOUMI, Aglaia. Transatlantische Begrifflichkeiten. Anmerkungen zum interkulturellen Diskurs in Deutschland und den USA. In: Dossier Migrationsliteratur Eine neue deutsche Literatur? Heinrich-Böll-Stiftung, 2009. 76-80.

Disponível em formato Pdf salvo em 20.07.2013:

http://www.migratio-boell.de/downloads/integration/DOSSIER_Migrationsliteratur.pdf] BOURDIEU, Pierre. Coisas ditas. Tradução de Cássia R. da Silveira e Denise Moreno Pegorim ; revisão técnica Paula Montero. - São Paulo : Brasiliense, 2004. 
BRITTO, Paulo Henriques. O Tradutor como mediador cultural. In: Synergies Brésil n. Especial. 2, 2010, p. 135-141.

CUNHA, Andrei dos Santos. Questões de tradução e adaptação em O Livro de Cabeceira. In: Tradterm, 21, 2013. p.71-95.

Disponível em formato Pdf, salvo em 17.12.2014:

http://myrtus.uspnet.usp.br/tradterm/site/images/revistas/v21n1/07_andreidossantos21f.pdf

EICHHORN, Hans. Die unerträgliche Leichtigkeit der Poesie. Marginalien zu Yoko Tawadas "Opium für Ovid". In: Text + Kritik. Zeitschrift für Literatur. n.191/192 Yoko Tawada. Richard Boorberg Verlag: Munique, 2011. p. 43-56.

EMMERICH, Wolfgang. Das Literarische Feld Deutschland - 15 Jahre nach der Wende. In: Revista de Filologia Alemana, Jg.14, 2006. 113-130.

GEISEL, Sieglinde. Kopfkissenbuch der Verwandlung. Die Anverwandlung literarischer Motive und Wahrnehmungsweisen von Ovid und Sei Shônagon in Yoko Tawadas "Opium für Ovid". In: Text + Kritik. Zeitschrift für Literatur. n.191/192 Yoko Tawada. Richard Boorberg Verlag: Munique, 2011. p. 47-53.

Entrevista: Ein Spaziergang mit Yoko Tawada - Fremdkörper Sprache, 2001. In: http://www.nzz.ch/article71HPS-1.468004. Última consulta em 04 /03/2017.

GOHN, Carlos (org.). As doçuras do sânscrito. FALE/UFMG: Belo Horizonte, 2006, p.9. Disponível em: http://www.letras.ufmg.br/site/publicacoes/download/docuras-site.pdf Em formato Pdf, salvo em 10/10/2014.

HORST, Clair. Immacolata. Interview mit Yoko Tawada: Fremd sein ist ein Kunst. In: Migrationsliteratur: Eine neue deutsche Literatur? Heinrich-Böll-Stiftung: Berlin, 2009.

Disponível em formato Pdf, salvo em 20.07.2013:

http://www.migration-boell.de/downloads/integration/DOSSIER_Migrationsliteratur.pdf INGHILLERI, Moira. The Sociologie of Bourdieu and the Construction of the "Object" in Translation and Interpreting Studies. In: The Translator. Volume 11, Número 2, 2005: 125-145.

KÄMMERLINGS, Richard. Das Kurze Glück der Gegenwart. Deutschsprachige Literatur seit '89. Stuttgart: Klett-cotta, 2011. 
LARANJEIRA, Mário. Poética da Tradução: Do Sentido à Significância. São Paulo: Editora da Universidade de São Paulo, 2003. (Criação e Crítica; v.12)

MESCHONNIC, Henri. Pour la poétique II. Epistémologie de l'ecriture poétique et de la traduction. Paris: Gallimard, 1973.

MOREIRA, Marcelo Victor de Souza. Estudos funcionais da tradução: rupturas e continuidades. Dissertação de Mestrado. FFLCH - USP, 2014.

MUNDAY, Jeremy. Introducing translations studies: Theories and Applications. London and New York: Routledge. (1. Ed.2001) 2 ed, 2008.

PREDEBON, Aristóteles. Edição do manuscrito e estudo das Metamorfoses de Ovídio traduzidas por Francisco José Freire. Tese de Mestrado. Orientador: Prof.Dr. João Angelo Oliva. Universidade de São Paulo, 2006.

RÖSCH, Heidi unter Mitarbeit von Yvonne Anzt (Stand: April 2013): Bibliografie deutschsprachige Migrationsliteratur mit Kurzporträts. Pädagogischen Hochschule Karlsruhe:

http://www.ph-karlsruhe.de/fileadmin/user_upload/hochschule/masterstudimm/MLBiblio.pdf

SAALFELD, Lerke von. Ich habe eine fremde Sprache gewählt. Gerlingen: Bleicher Verlag, 2002.

SAMOYAULT, Tiphaine. A intertextualidade. Tradução de Sandra Nitrini. Ed.Hucitec. São Paulo, 2008.

SCHLEIERMACHER, Friedrich. Über die Verschiedenen Methoden des Übersetzens / Sobre os diferentes métodos de Tradução. Edição bilíngue. Tradução de Margarete von Mühlen Poll. In: HEIDERMANN; Werner, (Clássicos da Teoria da Tradução). Florianópolis: UFSC, Núcleo de Tradução, v.1, 2001. Antologia Bilíngue: AlemãoPortuguês.

SCHOMANN, Stefan. Interview mit Yoko Tawada: Vom Schreiben in der Fremde. In: Chamisso: Viele Kulturen - eine Sprache. Robert Bosch Stiftung, 2009.

SIMEONI, Daniel. The pivotal status of the translator's habitus. Target 10 (1), 1998, $1-39$. 
SNELL-HORNBY, Mary e.T. - al (Hrsg.) - Handbuch Translation. Tübingen: Stauffenburg Verlag, 1998, p. 105-107.

TAWADA, Yoko. Verwandlungen. Tübinger Poetik-Vorlesung. Konkursbuchverlag, 1998.

TOURY, Gideon - Descriptive Translation Studies and beyond. Amsterdam / Philadelphia: John Benjamins, 1995.

VERMEER, J. Hans. Esboço de uma teoria da tradução. Edições Asa. 1985.

WAKISAKA, Geny; CORDARO, Madalena; Sobre a obra, a autora, o contexto e a tradução. Prefácio à tradução: SHÔNAGON, Sei. O Livro do Travesseiro. Editora 34: São Paulo, 2013. WELSCH, Wolfgang. Was st eigentlich Transkulturalität? Erschienen in: Bielefeld: Transkript Verlag (2010), 39-66. Vgl. auch: W. W., Immer nur der Mensch? Entwürfe zu einer anderen Anthropologie (Berlin: Akademie 2011), 294322.

\section{REFERÊNCIAS ON LINE}

Die Robert Bosch Stiftung. Fundação Robert Bosch:

http://www.bosch-stiftung.de/content/language $1 / \mathrm{html} /$ literaturfoerderung.asp http://www.bosch-stiftung.de/content/language $1 / \mathrm{html} /$ migration-und-integration.asp Editora konkursbuch:

http://www.konkursbuch.com/html/netfr2004/yokoAugeKapitel\%201.htm Helvetia Stiftung: http://www.prohelvetia.ch/FOERDERUNG.7.0.html Instituto Goethe - Goethe Medaille: https://www.goethe.de/de/uun/ver/gme.html Lista de traduções fomentadas:

http://www.goethe.de/ins/br/cur/bib/uef/bew/ptindex.htm

Literarisches Colloquium Berlin: http://www.lcb.de/home/

Revista Buchreport:

http://www.buchreport.de/analysen/100_groesste_verlage.htm?no_cache=112 http://www.buchreport.de/nachrichten/verlage/verlage_nachricht/datum/2009/03/31/m inus-auf-dem-mainstream/pointer/nachrichten.htm 
Statistisches Bundesamt:

https://www.destatis.de/DE/ZahlenFakten/GesellschaftStaat/Bevoelkerung/Migration Integration/Migrationshintergrund/Migrationshintergrund.html

S.Fischer Stiftung: https://www.betterplace.org/de/organisations/12554-s-fischerstiftung

\section{DICIONÁRIOS}

Duden. Deutsches Universalwörterbuch, 6. Aufl. Mannheim, 2006 [CD-ROM].

Langenscheidt KG, Berlin und München [CD-ROM]

Wahrig. Dicionário semibilíngue para brasileiros - Alemão. Martins Fontes: São Paulo, 2011.

Pons. Disponível em: https://www.pons.eu/

Houaiss. Dicionário Eletrônico da Língua Portuguesa. Objetiva, 2009.

\section{VERSÕES ANTERIORES DA TRADUÇÃo}

As versões da tradução anteriores às apresentadas neste trabalho podem ser obtidas pelo e-mail: alice.vale@usp.br ou acessadas online pelo link: https://www.dropbox.com/home/Alice\%20do\%20Vale 